Portland State University

PDXScholar

1986

Richard Whately's theory of argument and its influence on the homiletic theory and practice of John Albert Broadus

Robert Allan Vogel

Portland State University

Follow this and additional works at: https://pdxscholar.library.pdx.edu/open_access_etds

Part of the Intellectual History Commons, and the Theory, Knowledge and Science Commons Let us know how access to this document benefits you.

Recommended Citation

Vogel, Robert Allan, "Richard Whately's theory of argument and its influence on the homiletic theory and practice of John Albert Broadus" (1986). Dissertations and Theses. Paper 3665.

https://doi.org/10.15760/etd.5549

This Thesis is brought to you for free and open access. It has been accepted for inclusion in Dissertations and Theses by an authorized administrator of PDXScholar. Please contact us if we can make this document more accessible: pdxscholar@pdx.edu. 
AN ABSTRACT OF THE THESIS OF Robert Allan Vogel for the Master of Arts in Speech Communication presented May 19, 1986.

Title: Richard Whately's Theory of Argument and Its Influence on the Homiletic Theory and Practice of John Albert Broadus.

APPROVED BY MEMBERS OF THE THESIS COMMITTEE:

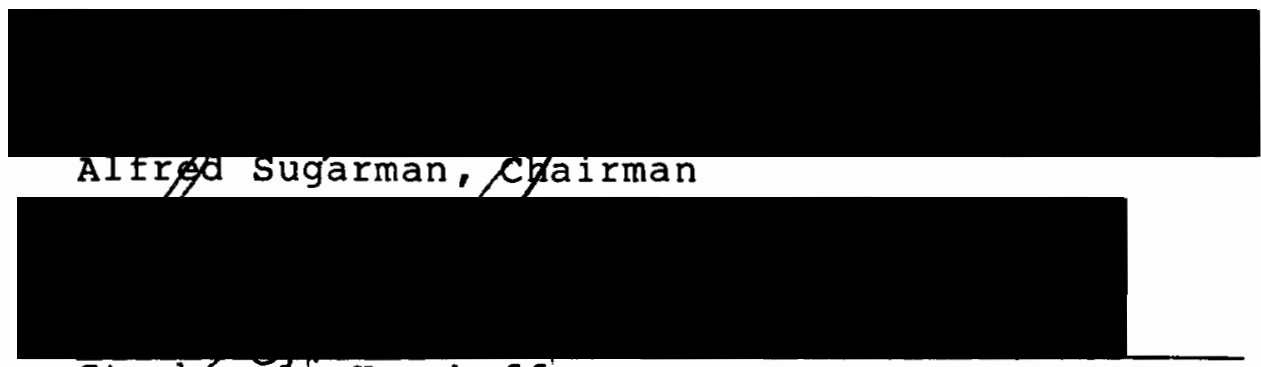

Stephén 6. Kosokoff

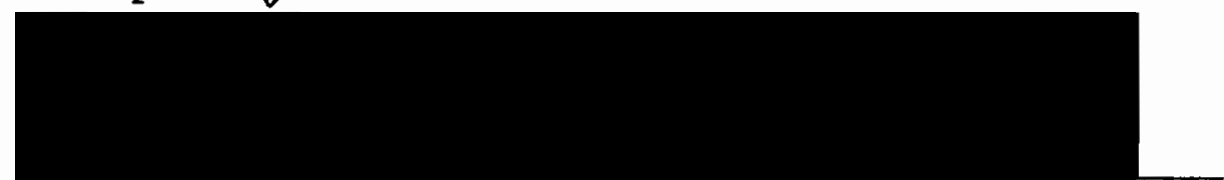

Larry steward

In his Treatise on the Preparation and Delivery of

Sermons, the southern Baptist preacher and educator of the latter nineteenth century, John A. Broadus, acknowledged the influence of classical and contemporary theorists upon his work. Among those named, particularly with regard to notions of argument, was Richard Whately, the Anglican Archbishop and rhetorical theorist of the early nineteenth century. The research task involved in this thesis was to determine whether 
and to what extent Whately's theory of argument was employed in Broadus's homiletic theory and practice.

The writer gathered his data using methods of documentary research. Most of the sources were available at local libraries. Others, however, were obtained from the Universities of Kansas, Iowa, and Michigan. Materials by and concerning Broadus were obtained from various Baptist historical agencies.

Both primary and secondary sources were consulted. The study of the respective theories of argument and the analysis of Broadus's discourses were done using primary sources. Secondary sources provided much helpful background and evaluation.

The writer examined Whately's theory of argument, as presented in his Elements of Rhetoric, in detail. He did the same with Broadus's theory as presented in his treatise. The two theories were then compared. It was assumed that Broadus was influenced by whately when either a direct reference to Whately was made or when there existed a similarity of ideas which could not be attributed to a common source. Differences between the theories of the two men were also noted.

From the ideas discovered in the study of Whately's theory, a paradigm for rhetorical analysis was constructed. The model for the paradigm was taken from Lawrence W. Rosenfield's essay, "The Anatomy of Critical Discourse." The elements of argument included in the paradigm were presumption and 
burden of proof, arguments from testimony, analogy, and progressive approach, and refutation. These were chosen because, in the opinion of experts, Whately either created or significantly developed them.

The paradigm was used as a standard of analysis for three of Broadus's discourses, namely, "The Duty of Baptists to Teach Their Distinctive Views," "Should Women Speak in the Mixed Public Assemblies?" and "Immersion Essential to Christian Baptism."

The analysis of Broadus's theory and practice, done by this writer, confirms the notion that whately's ideas influenced Broadus significantly. Broadus's concepts of argument from testimony, analogy, and progressive approach and his principles of refutation bear the unmistakable influence of the Archbishop. Concerning the important matters of presumption and burden of proof, Broadus pointedly disagreed with whately in theory. In one of the discourses analyzed, however, the writer concluded that Broadus followed Whately's notions of burden of proof rather than his own.

The writer concluded that Broadus's use of Whately's ideas demonstrated their usefulness in the task of preaching. The findings of this study confirm the opinions of others who hold whately's theory in high regard. 


\title{
RICHARD WHATELY'S THEORY OF ARGUMENT AND ITS INFLUENCE ON THE HOMILETIC THEORY AND PRACTICE OF JOHN ALBERT BROADUS
}

by

ROBERT ALLAN VOGEL

A thesis submitted in partial fulfillment of the requirements for the degree of

\author{
MASTER OF ARTS \\ in \\ SPEECH COMMUNICATION
}

Portland State University

1986 
TO THE OFEICE OE GRADUATE STUDIES AND RESEARCH:

The members of the Committee approve the thesis of

Robert Allan Vogel presented May 19, 1986.
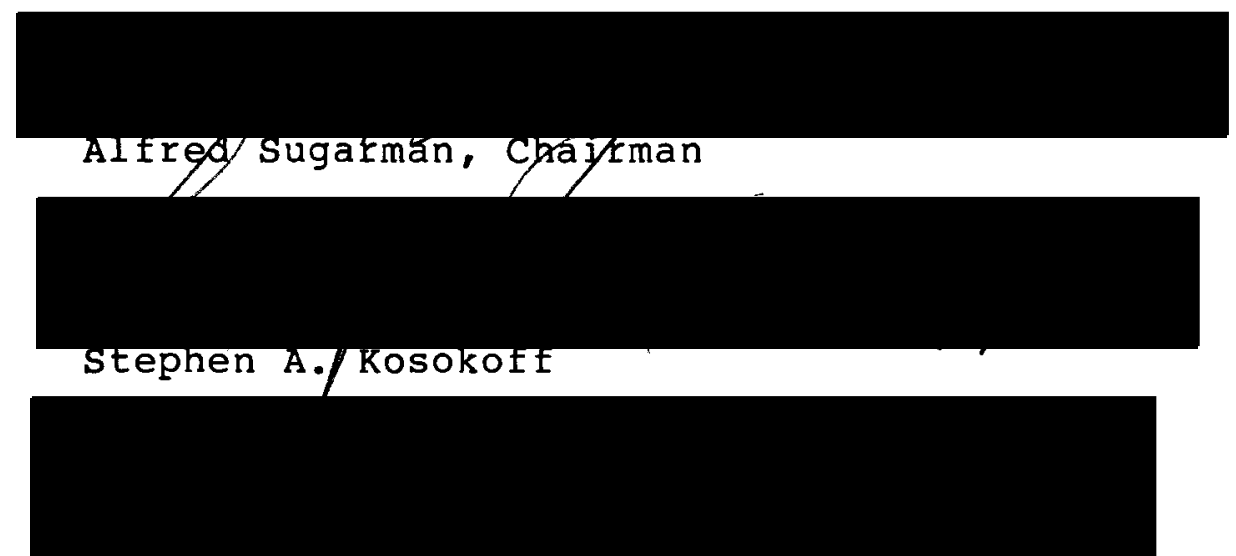

Larry /steward

\section{APPROVED :}

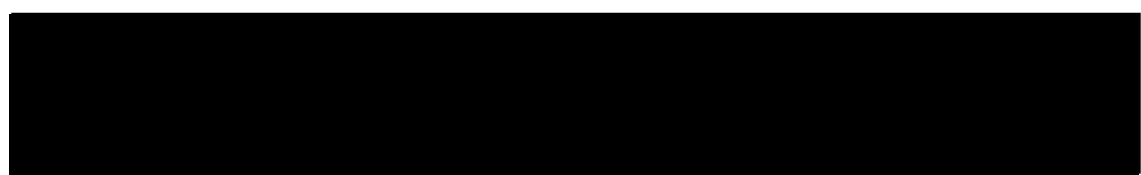

Theodore G. Grove, Head, Department of Speech Communication

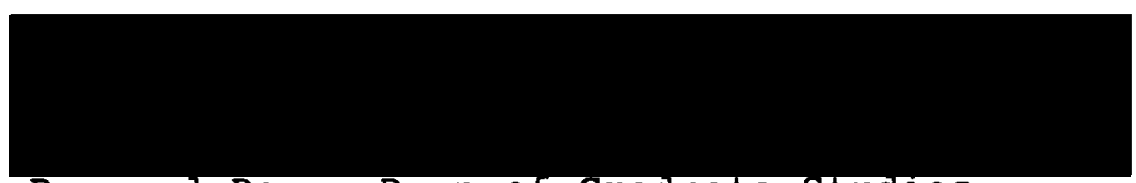

Bernard Ross, Dean of Graduate studies and Research 


\section{ACKNOWLEDGEMENTS}

Like most endeavors in the writer's life, this thesis has been made possible through the efforts of others besides himself. I extend thanks to my advisory committee, and particularly to Dr. Alfred Sugarman, who provided careful oversight of the work. I have appreciated the encouragement of these men and have learned much from their suggestions.

Thanks are also due to the administrative officers of the Western Conservative Baptist Seminary, who have provided financial assistance for my academic program. Most of all, I must thank my wife, kathy, and my children, John, Janet, and Julie for the sacrifices they have made over the five years of my master's program. Without complaining they have lived with an erratic schedule, given up vacations and other family times, and endured the slights of a husband and father preoccupied with his academic pursuits. They have borne a share of the labor. To them belongs a share of the reward. 
TABLE OF CONTENTS

PAGE

ACKNOWLEDGEMENTS

CHAPTER

I INTRODUCTION • • • • • • • • • • • • • •

The Significance of Broadus and Whately . . . . . . . . .

Purpose and Rationale... . . . . 8

Review of the Literature ...... . 9

Methodology . . . . . . . . . 13

Plan of organization . . . . . . 19

I I RICHARD WHATELY'S THEORY OF ARGUMENT $\cdot . \cdot 21$

Background of Richard Whately . . . . . 21

An Overview of the Elements of

Rhetoric . . . . . . . . . .

Particulars of Whately's Theory . . . . 37

Arguments from Sign . . . . . . 38

Testimony . . . . . . . . 38

Progressive Approach . . . . . . 45

Arguments from Example . . . . . . 46

Selection and Use of Arguments . . . 50

The Aim of an Argument . . . . . . 51

Presumption and Burden of Proof . . 51 
Refutation . . . . . • . . . .

Whately's Contributions to Rhetoric . .

II I JOHN BROADUS'S THEORY OF ARGUMENT • • • •

Background of John Broadus . . . . . .

An Overview of Broadus's Theory . . . .

A Comparison of the Theories of Whately and Broadus . . . . . . . . .

Questions Preliminary to Argument . .

Burden of Proof

Presumption

Principal Varieties of Argument . . .

Argument from Analogy

Argument from Testimony

Forms of Argument . . . . . . . . .

Refutation

Summary

IV A RHETORICAL ANALYSIS OE SELECT DISCOURSES OF JOHN A. BROADUS • . . . . . . . . . 120

A Model for Critical Discourse . . . . . 121

A Paradigm Based Upon Whately's Theory . . 124

An Analysis and Assessment of Three

Discourses of John Broadus . . . . .

"Duties of Baptists to Teach Their

Distinctive Beliefs" . . . . . . .

Background of the Address

An Overview of the Address

An Analysis and Assessment of the Arguments

Summary 
"Should Women speak in Mixed Public

Assemblies?" . . . . . . . . . 148

Background of the Discourse

An Overview of the Discourse

An Analysis and Assessment of the Discourse

summary

"Immersion Essential to Christian

Baptism" . . . . . . . . . 168

Background of the Discourse

An Overview of the Discourse

An Analysis and Assessment of the Discourse

Summary

Conclusion ............ 190

v COnClusion . . . . . . . . . . . . 194

Summary . . . . . . . . . . 194

Conclusions . . . . . . . . . . 199

Suggestions for Further Study . . . . 203

SELECTED BIBLIOGRAPHY . . . . . . . . . . 205 


\section{CHAPTER I}

\section{INTRODUCTION}

The study of argument as a rhetorical process is nothing new. Aristotle and others of his day recognized and described the process as it was employed in the establishing of propositions in various speaking contexts.

The study of rhetorical process in preaching is nothing new, either. St. Augustine in his treatise on Christian Doctrine, Book IV, established the propriety of applying classical rhetorical concepts to the practice of preaching. Therefore, it is to be expected that argument theory, though in the minds of some a secular notion, could be applied to preaching.

Various homileticians have discussed the application of argument theory in preaching. Among these were Richard Whately, an Anglican archbishop of the early nineteenth century, and John Broadus, a Southern Baptist educator and preacher of the latter nineteenth century. This thesis involves the joining of the work of these two men and their ideas concerning the use of argument in preaching. 


\section{The Significance of Broadus and Whately}

Background Concerning John Broadus

One of the most significant men in the history of Baptists in America is John Albert Broadus, scholar, educator, and pulpit orator. During his lifetime (18271895), Broadus made significant contributions to the work of Baptists in the south. Some of these accomplishments are presented below.

His participation in the founding and developing of the Southern Baptist Seminary was his primary life's work. Although he taught in several disciplines at the seminary with scholarly credibility, he is probably most widely known as a teacher of preaching. Broadus has left his mark both as a theorist and practitioner of homiletics upon the students he taught as a professor at the seminary, and in succeeding generations through his treatise on the Preparation and Delivery of Sermons. Concerning the excellence of his homiletic theory and practice, professor W. C. Wilkinson of the University of Chicago wrote:

Every characteristic I have now pointed out as found with Doctor Broadus in the teacher of preaching is found also with him, and more rather than less, in the preacher. His practice well comports with his theory--comments and commends it. To the thoughtful student of both the theory and practice of the man, it becomes evident that in Doctor Broadus's case the practice preceded the theory. But it becomes equally evident that also 
the theory following reacted, as it should do, confirming the practice....1

E. Y. Mullins, who was one of Broadus's successors as president of Southern Baptist seminary noted the extent of Broadus's influence when he wrote:

It may be said without exaggeration that Dr. John A. Broadus, the first teacher of Homiletics in the Southern Baptist Theological Seminary, did more than any other man of his generation in the south to create pulpit ideals for the Baptist ministry. Indeed, his influence was felt in all parts of the country and the world....2

Broadus was a popular preacher and speaker. A survey of his engagement book reveals that he was ingreat demand among the churches of both the south and the north--no small matter in the years surrounding the Civil War. His reputation as a scholar of preaching was such that he was invited to deliver the 1888-89 Lyman Beecher Lectures on Preaching at Yale, the only Southern Baptist ever accorded the honor. 3

${ }^{1}$ An Eminent Professor of Homiletics, "Criticisms of Some of the Ablest Representative Preachers of the Day: Rev. John A. Broadus, D.D.," Homiletic Review XVI (August, 1888). In $\mathrm{Life}$ and Letters of John $A$. Broadus, p. 367, the "eminent professor" is identified as W. C. Wilkinson, who served at the University of Chicago.

2 E. Y. Mullins, "The Seminary and Preaching," The Baptist Argus, VI (May 1, 1902), p. 5, cited by James Roland Barron, "The Contributions of John A. Broadus to Southern Baptists" (unpublished doctoral dissertation, Southern Baptist Seminary, 1972), p. 180.

${ }^{3}$ Vernon L. Stanfield, Favorite Sermons of John A. Broadus (New York: Harper Brothers Publishers, 1959), p. 5 . 
Besides teaching at the seminary and preaching in the churches, Broadus frequently addressed meetings of local Southern Baptist associations as well as those of the Southern Baptist Convention at large. His speaking gave him national prominence and significant influence during the first fifty years of the Convention's existence.

These accomplishments make Broadus a man worthy of study for students of preaching in general and students of evangelical Baptist preaching in particular.

The Influence of Richard Whately on Broadus

One of the major aspects of Broadus's homiletic theory involved the use of argument in preaching. The importance of this subject to Broadus is expressed in the preface to his Treatise, where he wrote:

The subject of Argument is thought by some to be out of place in a treatise on Homiletics or on Rhetoric in general. But preaching and all public speaking ought to be largely composed of argument, for even the most ignorant people constantly practice it themselves, and always feel its force when properly presented; and yet in many pulpits the place of argument is mainly filled by mere assertion and exhortation, and the arguments employed are often carelessly stated, or even gravely erroneous. 4

${ }^{4}$ John A. Broadus, A Treatise on the Preparation and Delivery of Sermons, Fourteenth ed. (New York: A. C. Armstrong, 1889), p. x. 
No doubt, the importance of good argument (as well as other elements of homiletic theory) was impressed upon Broadus by other theorists whom he read. In his Treatise he freely admits the influence of others on his work. Among those he mentioned are Aristotle, Cicero, Quintillian, Alexandre Vinet, James W. Alexander, W. G. T. Shedd, and James M. Hoppin. 5

In his section on argument, he asserted that Richard Whately, the Anglican Archbishop whose Elements of Rhetoric was published in 1828 , had the greatest influence. Broadus expressed his interest in whately's theory of argument most specifically in his discussion of homiletic literature. He wrote, "Whately's Rhetoric is believed to be the best treatise for practical use that has appeared. Especially valuable are the portions on Argument and on Style."6 This opinion is again affirmed in a footnote

${ }^{5}$ Ibid., p. x. Vinet, a French homileticican, wrote Homiletics, or the Theory of preaching. The work was published after his death in 1847. It was translated into English by Thomas H. Skinner, Professor of Sacred Rhetoric and Pastoral Theology at Union Theological Seminary, New York, in 1854. Alexander taught homiletics at Princeton Theological Seminary. His book, Thoughts on Preaching, was published posthumously in 1860 . Shedd, a professor at Union Theological Seminary in New York, wrote Homiletics and Pastoral Theology in 1867. Hoppin filled the Chair of Homiletics in the Divinity School of Yale University when, in 1869, his office and Work of the Christian Ministry was published. For further information, see E. C. Dargan, The Art of Preaching in the Light of Its History (New York: George H. Doran Company, 1922), pp. 184, 220-222.

6 Ibid., p. 32 . 
(appearing early in his chapter on argument) in which he said, "In this chapter much use is made of whately, whose discussion on Arguments is the most valuable part of his work on Rhetoric, and unequalled by other treatises."7 Broadus's opinion of the excellence of Whately's work is widely shared. One who highly praised whately's work was Sir Richard C. Jebb, the English classical scholar of the nineteenth century. Comparing whately to Blair and Campbell, Jebb wrote, ". .undoubtedly the best modern book on the subject is Richard Whately's Elements of Rhetoric. ${ }^{8}$ Orville Pence quoted twelve different writers who testified to the excellence of Whately's ideas set forth in his Elements of Rhetoric and its companion, his Elements of Logic. ${ }^{9}$ Golden, et al., more contemporary writers, note the significance of the Elements of Rhetoric "as a historical document and as a moulder of contemporary argumentation theory."10 Ehninger made the following

\section{Ibid., p. 162 .}

${ }^{8}$ Encyclopedia Britannica, 11 th ed., s.v. "Rhetoric," by R. C. Jebb.

${ }^{9}$ Orville Pence, "The Concept and Function of Logical Proof in the Rhetorical system of Richard Whately" (Ph. D. dissertation, University of Iowa, 1946), pp. 13-15.

10 James L. Golden, Goodwin F. Berquist, and William E. Coleman, The Rhetoric of Western Thought, 2 nd ed. (Dubuque: Kendall/Hunt Publishing Company, 1978), p. 136. 
statement regarding Whately's work:

Because Whately's decisions on some of the major questions in rhetoric have proved sound and fruitful through many years of practice, the Elements, while not to be numbered among the great creative works on the subject, is certainly to be ranked among the most influential. For the same reason, though now a century and a third old, it has much to say to the student of rhetoric yet today.ll

The value of Whately's work to Broadus was no doubt enhanced by their mutual interest in the application of the theory of argumentation to preaching. Being a clergyman, Whately oriented his theory specifically toward religious discourse. Golden states that Whately's extreme devotion to Christianity so shaped his system of argumentation that his approach could well be called an ecclesiastical rhetoric. 12

Although Broadus respected Whately's theory, he did not merely copy it. While admitting that he freely employed Whately's work, he developed the subject of argument "with very large additions, and with the attempt to correct some important errors"13 in Whately's work.

ll Richard Whately, Elements of Rhetoric, ed. Douglas Ehninger (Carbondale: Southern Illinois University Press, $1963)$, p. $\times x \times$.

12 Ibid., p. 137. Ehninger, in the introduction to his critical edition of Whately's Elements of Rhetoric makes a similar statement.

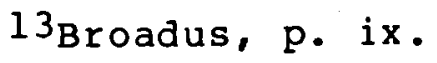




\section{Purpose and Rationale}

The purpose of this study is to trace the influence of Richard Whately's theory of argument on John Broadus's theory and practice of preaching. Such a study is desirable because both of these men are widely recognized for their influence on the rhetoric of preaching. The extent of their influence and reasons for their fame have been briefly cited above.

Sublevels of purpose and rationale are related to specific directions the study is taking. One goal of the study is to expound and compare the theories of argument of both men. The exposition provides a brief but useful synopsis of two similar theories of argument. The discussion of Whately's influence and Broadus's criticisms of Whately's theory provide a comparative evaluation of both theories. The description and evaluation of models of argumentation, should be useful in the ongoing development of rhetorical theory.

Another goal of the study is to describe and evaluate the practical application of Whately's theory by applying procedures of rhetorical criticism to a select few of Broadus's discourses. Three have been chosen for this kind of analysis: "Duty of Baptists to Teach Their Distinctive Views," "Immersion Essential to Christian Baptism," and "Should Women Speak in Mixed Public 
Assemblies?" These particular addresses were chosen according to criteria which are stated subsequently in this chapter.

\section{Review of the Literature}

Works Concerning Whately

The work of prime importance for analyzing Whately's theory in this study is his own Elements of Rhetoric. Part I, sections $1-3$, contains his statement concerning argument. Helpful commentary is included in the Douglas Ehninger edition of this work (1963.)

Numerous works have been written about whately's theory. Maxfield Parrish discussed that theory, as influenced particularly by Coplestone and Aristotle, in "Whately and His Rhetoric" Quarterly Journal of Speech, February, 1929.) Parrish's doctoral dissertation (Cornell University, 1929) also concerned whately, but treated his oxford background, his college reading, the various editions of his works, and his sources rather than his notions regarding logical proof.14 Ehninger's article, "Campbell, Blair, and Whately Revisited" (Southern Speech Journal, spring, 1963) traces the influence of classical models upon whately. (This article is a refinement of an 
article by Ehninger in the Southern Speech Journal, October, 1955.) Pomeroy's article, "Whately's 'Historic Doubts': Argument and Origin" Quarterly Journal of Speech, February, 1963) includes some useful personal background on whately, although most of the article does not deal with his rhetoric. James Golden's The Rhetoric of Blair, Campbell, and Whately (1968) includes an edited version of the Elements of Rhetoric. Golden's collaboration with Berquist and Coleman, The Rhetoric of Western Thought (1976) includes a synopsis and brief analysis of Whately's notions of presumption and burden of proof.

Some other works concentrate on the narrower aspects of argument in whately. A definitive examination and evaluation of logical proof in Whately's rhetoric, particularly as compared with Aristotle's Rhetoric, was undertaken by Orville Pence in his dissertation entitled, "The Concept and Function of Logical Proof in the Rhetorical System of Richard Whately" (unpublished dissertation, University of Iowa, 1946). Pence in a subsequent journal article ("The Concept and Function of Logical Proof in the Rhetorical System of Richard Whately," Quarterly Journal of Speech, March, 1953) analyzed the Archbishop's view of conviction. Anderson and Hayes lquarterly Journal of Speech, June, 1967) summarize Whately's idea of burden of proof and demonstrate how he applied it in one of his speeches. Leathers (Southern Speech Journal, Winter, 
1969), comparing Whately to John Stuart Mill, asserted that whately was anti-empirical in his approach to proof.

\section{Works Concerning Broadus}

The primary source for examining Broadus's theory is his own Treatise on the Preparation and Delivery of Sermons. Of specific interest is Part I, Chapter VI, entitled "Argument." This book originally appeared in 1870, which was early in Broadus's career. Through subsequent years, he made several notations of revisions which he wished to incorporate in a new edition of the book. Broadus died before he could publish a revision, but within two years of his death his associate at southern Baptist Seminary, E. C. Dargan, prepared a revision based primarily upon Dr. Broadus's notes and incorporating his verbal ideas.15 A comparison of the two volumes on the subject of argument discloses changes in organization, but none in substance.

Among the literature concerning Broadus's life and work are The Seminary Magazine, Broadus Memorial Edition (Apri1, 1895), C. L. Cocke's "An Address on the Character of John Albert Broadus, before the Baptist General Assoc-

$15 \mathrm{John}$ A. Broadus, A Treatise on the Preparation and Delivery of Sermons, rev. E. C. Dargan (New York: Hodder and Stoughton, 1898), pp. vi, vii. 
iation of Virginia" (November 17, 1895), and A. T. Robertson's Life and Letters of John Albert Broadus

(1901). Among more recent works is James Roland Barron's dissertation, "The Contributions of John A. Broadus to Southern Baptists" (Southern Baptist Seminary, 1972.) Barron described Broadus's accomplishments during his career and thus provides useful personal background concerning the man.

Probably the major work on Broadus's homiletical theory has been "A Study of the Rhetorical Theories of John A. Broadus" by Paul Huber (unpublished doctoral dissertation, University of Michigan, 1956). Huber's work summarized Broadus's theory and identified the influence of writers Broadus quoted in his treatise. In the fourteen pages devoted to his theory of argument, whately's influence, among others, is discussed. Jerry Paxton Ashby ("John Albert Broadus: The Theory and the Practice of His Preaching," New Orleans Baptist Theological Seminary, 1968) determined to compare Broadus's theory with his practice. Using the Weatherspoon revision of Broadus's treatise as a basis, he studied 250 of Broadus's manuscripts to determine the extent to which Broadus applied various aspects of his theory. The work advanced Huber's study by considering the sermons of Broadus, but the analysis of so many speeches resulted in superficial 
treatment. The statistical nature of the report was accompanied by only minimal analysis of sermon content. For purposes of the present study, Broadus's sermons, addresses, and writings are also relevant literature. Broadus himself published his favorites in sermons and Addresses (1886). V. L. Stanfield edited a collection of twenty-four sermons entitled Favorite Sermons of John A. Broadus (1959). Several addresses and written discourses were published in pamphlet form. Among these are "Denominational Sermon: The Duty of Baptists to Teach Their Distinctive Views" (1881), "The Study of the Bible by Books, its Advantages" (1881), "Three Questions as to the Bible" (1883), "Should women Speak in Mixed Public Assemblies?" (1890),16 "Immersion Essential to Christian Baptism" (1892), and "Christianity Essentially Missionary" (1893).

\section{Methodology}

The purpose of this thesis is to trace the influence of Whately's theory of argument on the theory and practice of Broadus. The methods selected, therefore, had to enable the achievement of two goals. First, they had to expose the theories of the two men, covering their

${ }^{16}$ He said that they should not. 
similarities and differences. Second, they had to provide a vehicle for rhetorical criticism of Broadus's sermons and addresses.

The achievement of the first objective was essential to the accomplishment of the second. The first procedure produced a model for argumentation, which became the standard for the criticism of Broadus's practice.

of first priority was the description of Whately's theory of argument as set forth in his work, Elements of Rhetoric. Elaboration from secondary sources named in the literature review enhanced this description. The theory has been summarized to identify the major elements of argument and their relationships to one another.

The second procedure was to describe Broadus's theory, drawn from his chapter on argument in his treatise and elaborated through research in secondary sources. Significant in this description was the comparison of Broadus's ideas concerning argument with those of Whately. It has been assumed that Broadus was influenced by whately when either a direct reference to whately is made or when there exists a similarity of ideas which cannot be attributed to a common source. Differences between whately and Broadus have also been noted.

This procedure accomplished two objectives. First, it provided a summary model of argument, which could be used as Broadus's own standard for rhetorical analysis of 
his sermons and addresses. Second, it traced the influence of Whately on Broadus's theory.

Having described the theories of both men, the writer then turned to the second goal, using methods of rhetorical analysis to assess whether and how Broadus applied his theory of argument. Specifically, three addresses and written discourses, selected for diversity of occasion and purpose yet all dealing with controversial subjects, were analyzed.

The criteria used for selecting the addresses and discourses were as follows. First, the addresses chosen had to be available. Although this criterion is obvious, it is not as insignificant as it might appear. Because Broadus generally preached extemporaneously rather than from a manuscript, only a relatively small number of his sermons and addresses were ever available in print. Furthermore, it is likely that with the passing of time many of the records have been lost. Although the number of available sermons, addresses, and discourses is somewhat limited, there is a sufficient number for purposes of analysis.

Second, the addresses were chosen for either their controversial content or their persuasive intent. It is self-evident that one would argue to establish a viewpoint that is disputed. The titles, introductory comments, 
and central propositions of twoll of the three chosen clearly indicate divided opinion concerning their topics. It is also self-evident that argument is naturally a part of persuasion. In onel8 of the three it is evident that Broadus desired to move his audience to adopt a course of action, which required some argument to persuade. It is, therefore, reasonable to expect that Broadus would employ his theory and skills of argument to establish his viewpoint regarding each of the subjects at hand.

Implied by the second criterion is the third, namely, that the development of those discourses chosen must involve at least some argument. Argumentation would naturally be expected by the nature of the propositions involved, but if Broadus had not met the natural expectation, little analysis essential to this study could be done.

The fourth criterion was that the address could be one originally either spoken or written. This is not to deny the significant differences between oral and written discourse. Rather, it is to suggest that these differences, such as style, are irrelevant to the interest in argument involved in this study. Whether written or

17"Immersion Essential to Christian Baptism" and "Should Women Speak in Mixed Public Assemblies?" Views"

18 "The Duty of Baptists to Teach Their Distinctive 
spoken, the arguments presented were directed toward an identifiable audience, were relative to a stated proposition, and involved a clear purpose, either expressed or implied.

The rhetorical analysis followed the eclectic model of Lawrence W. Rosenfield, set forth in his essay, "The Anatomy of Critical Discourse."19 According to Rosenfield, in critical discourse verdicts (i.e., judgments or evaluations) are pronounced, and reasons justifying the verdicts are offered.20 Because such is the nature of critical discourse, it is like forensic reasoning, in which observations are juxtaposed with normative standards in some fashion. 21 In short, Rosenfield proposes that one evaluates what he's criticizing by comparing the criticized entity to a standard.

Rosenfield further suggests procedures for relating the norm and the observation. One means he describes is a "model modality." In this approach the critic begins by generating a paradigm (an "exemplar of a kind") which will

${ }^{19}$ Lawrence Rosenfield, "The Anatomy of Critical Discourse," in Methods of Rhetorical Criticism: A. Twentieth Century perspective, second ed., revised, eds. Bernard L. Brock and Robert L. Scott (Detroit: Wayne State University Press, 1980), pp. 148-74.

20 Ibid., pp. 153-55.

${ }^{21}$ Ibid., pp. $156 \mathrm{ff}$. 
be his basis for comparison. 22 From the comparison follows

-..akind of diagnosis; if the model conforms to the critic's rhetorical theory (as we must assume it does if it is to be regarded as a paradigm), then disparity between the norm-discourse and the actual one should provide some insight into both the aesthetic excellence and the rhetorical weaknesses evident in the discourse being inspected.

The analysis can, in turn, become a critique of the standard as well. The critic may search for reasons to account for deviation from the model in the criticized entity. The explanation for the extent and character of deviation constitutes the invention of critical reasons. 24

The application of Rosenfield's procedure, then, begins with the construction of a model. The model, or paradigm used in this study was that of Whately. The rhetorical analysis of Broadus's addresses required juxtaposing them against whately's paradigm. The analysis describes the phenomenon, evaluating how well Broadus's practice conforms to whately's theory. In turn, explanations for deviation have been suggested in order to judge the paradigm itself.

Background information for each address or discourse was examined when possible. It was expected that the

$$
\begin{aligned}
& 22 \text { Ibid., p. } 170 . \\
& 23 \text { Ibid. } \\
& 24 \text { Ibid., p. } 171 .
\end{aligned}
$$


occasion of each and the audience's opinions concerning the subject would determine the argument employed.

\section{Plan of organization}

The thesis consists of five chapters. The first introduces the subject, presenting its purpose and rationale, reviewing the pertinent literature, and describing the methodology employed in the study.

Chapter Two provides personal background of Richard Whately and selectively develops his theory of argument.

Chapter Three includes background information concerning John Broadus, and selectively presents his theory of argument. Through comparison, the influence of Whately's theory is traced.

Chapter four consists of the rhetorical analysis of three addresses or written discourses based upon a model derived from Whately's theory of argument as presented in the second chapter. Description and evaluation are included.

Chapter Five includes a summary analysis of the findings of the study. Conclusions are drawn respecting the extent to which Broadus followed Whately's model, and how he may have veered from it. Judgments are offered concerning the value of the paradigm itself. Also included are suggestions for further study. 
As Broadus pointed out, even the most ignorant of men practice argument, and feel its force when it is properly done. 25 However, in pulpits and other public forums argument is regularly abused. It is the author's hope that this thesis will strengthen the abilities of its readers to argue a point in an excellent manner, not only for the sake of contemporary rhetoric, but also for the sake of truth.

25 Broadus, 14 th ed., p. ix. 
CHAPTER II

\section{RICHARD WHATELY'S THEORY OF ARGUMENT}

As stated in the previous chapter, the inquiry of this thesis concerns the influence of Richard whately's theory of argument on the homiletic theory and practice of John Broadus. It is, therefore, logical to begin the investigation with a description of Richard Whately's theory of argument. In this chapter, the writer will provide a brief sketch of Archbishop Whately's life, an overview of his theory, an exposition of selected elements of argument he set forth in his Elements of Rhetoric, and an assessment of his contributions to the study of rhetoric.

\section{Background of Richard whately}

Richard Whately was born in London, England on February 1, 1787, the son of Joseph whately, prebendary of Bristol.1 As a child confined to the indoors due to delicate health, he developed an interest in books early in 1 ife. His reading even as a child piqued his interest in mathematics, ethics, and politics. These disciplines Richard."

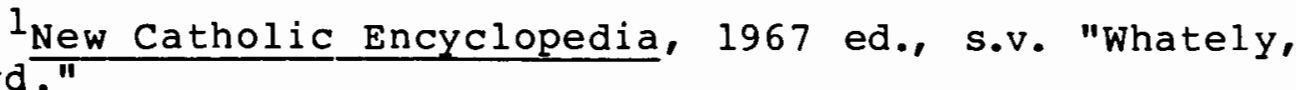


proved to be foundational to his later interests in logic, the Church, and political economy. ${ }^{2}$

In 1805, Whately was admitted to oriel college, oxford. He completed his B. A. degree in 1808, was elected Fellow of oriel, and earned his M. A. in 1812. Soon after his degree was conferred, he was ordained an Anglican clergyman. In 1825, after spending four years in a pastorate at Halesworth in Suffolk, Whately became principal of St. Alban Hall, Oxford. 3 In 1829, he was appointed Professor of Political Economy at oxford, a position which suited his "lucid, practical intellect."4

In 1831, Whately resigned his position at oxford to accept the call to become Archbishop of St. Patrick's Cathedral in Dublin. He served in this position until 1853.5 From this office, he became involved in the poli-

2 James L. Golden and Edward P. J. Corbett, The Rhetoric of Blair, Campbell, and Whately (New York: Holt, Rinehart and winston, Inc., 1968), p. 273.

3 Ibid.

${ }^{4}$ Encyclopedia Britannica, 11 th ed., s.v. "Whately, Richard." However, Parrish notes that his interest in political economy was largely underdeveloped due to his greater concern for theological matters. Wayland Maxfield Parrish, "Whately and His Rhetoric," Quarterly Journal of Speech 15 (February 1929): 68 .

${ }^{5}$ Kenneth s. Latourette, Christianity in a Revolutionary Age, vol. 1: The Nineteenth Century in Europe (New York: Harper and Brothers, Publishers, 1959), p. 397. 
tical, social, and religious ferment of his day. Although he supported Catholic emancipation and reforms intended to help the Irish poor, he was not popular in Dublin, 6 for he was an Englishman and a Protestant. 7

In his later years, whately's health failed. For this reason he spent most of his time in his study. After an extended illness, he died on october 1, 1863, and was buried in st. Patrick's Cathedral.8

\section{Whately the Controversialist}

His years as a student and tutor at oxford were extremely important in shaping the ideas and personal traits for which whately would become known. His tutor at the University was Edward Coplestone. Coplestone, who himself wrote satirical and argumentative works, sharpened Whately's taste for controversy. ${ }^{9}$ whately's emerging interest in theological issues, coupled with his flair for controversy, is evident in his satiric pamphlet, "Historic Doubts Relative to Napoleon Bonaparte," written in 1819.

${ }^{6}$ Golden and corbett, p. 274 .

${ }^{7}$ F. R. Webber, A History of Preaching in Britain and America, 3 vols. (Milwaukee: Northwestern Publishing House, 1952-57), 1:533.

${ }^{8}$ Golden and Corbett, p. 275.

${ }^{9}$ Parrish, p. 59. 
Although he regularly disclaimed controversial intent, this particular tract was quite provocative. 10

The purpose of the pamphlet was to show that the conclusions of sceptical criticism, as advocated by Hume, were based upon fallacies. Hume had argued that the miracles recorded in the Bible cannot be accepted on the basis of human testimony. Heavily employing the reductio ad absurdum argument, and using Hume's critical procedures, Whately argued that the existence of Napoleon Bonaparte could not be admitted as a "well-authenticated fact."ll In other words, applying "the same methods used to cast doubt on Biblical miracles would also leave open to question the existence of Napoleon Bonaparte."12

Whately and the Noetic School

Whately's penchant for controversy extended not only to the sceptics of his day. The Archbishop regularly found himself at odds with churchmen as well. During his years at oxford, whately witnessed the birth and growth of the Tractarian movement. In the early years he was a

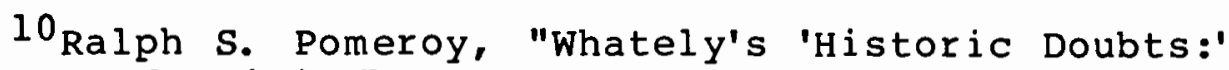
Argument and origin," Quarterly Journal of Speech 49 (February, 1963): 62 .

11 Ibid., p. 62 .

12 Encyclopedia Britannica, 15 th ed., s.v. "Whately, Richard." 
close friend of most of the Tractarians. In time however, because he could not comprehend the beliefs of the Tractarians and the Low Church party, he came to hold those groups in comtempt. Their doctrines, he believed, were tinged with superstition.13 while at oriel, therefore, Whately was among those who formed the so-called "Noetic" school. Being less inclined toward a mystical view of religion than the Tractarians 14 were, the Noetics called everything into question. This inquisitive environment prompted the development of natural independence and originality of thinking which would later be expressed in his works on logic and rhetoric. 15

To both the High Churchmen and the Evangelicals, his view of Christianity seemed to be little better than

\footnotetext{
13 Encyclopedia Britannica, llth ed., s.v. "Whately, Richard."
}

14 The inclination of the Tractarians was toward many of the religious practices of the Roman Catholic Church. Among these were the historic episcopacy and apostolic succession, emphasis upon the Eucharist, and many preReformation practices of the Anglican Church. These included such things as auricular confession, the use of vestments, incense, candles, the eastward position of the altar, and intoned services. Whately's opposition to the movement culminated in a break with his friends when Tract $X C$, which would have made possible for Anglicans the Catholic practices of the invocation of Saints, belief in purgatory, and the use of images. For further discussion of the movement, see Latourette, pp. 264-270.

15 parrish, pp. $62,63$. 
rationalism. 16 However, in fundamental matters, he was considered to be orthodox and conservative.17 Concerning his theological attitude, Golden and Corbett wrote:

Al though he was a close friend of most of the Tractarians in the early days of the oxford Movement, he gradually drifted away from them ideologically and finally broke with them over the affair of the famous Tract XC. . . Part of his disaffection with the whole oxford Movement was due to his congenital antipathy for metaphysical and theological speculations. The principle that governed the stand he took in all religious controversies was Chillingworth's premise that "the Bible, and the Bible alone, is the religion of Protestants." And it was this allegiance to the Scriptures that accounts for the emphasis he puts on testimony in his Elements of Rhetoric. ${ }^{18}$

A similar perspective on his theological method and the genuineness of his religion is expressed below. He may be said to have continued the typical christianity of the 18 th century--that of the theologians who went out to fight the Rationalists with their own weapons. It was to Whately essentially a belief in certain matters of fact, to be accepted or rejected after an examination of "evidences." Hence his endeavor always is to convince the logical faculty, and his christianity inevitably appears as a thing of the intellect rather than of the heart. 19

16 Britannica, 11 th ed., s.v. "Whately, Richard."

17 parrish, p. 66.

18 Golden and Corbett, p. 274.

19 Britannica, llth ed., s.v. "Whately, Richard." 
Perhaps some of the conflict in which he was involved can be attributed to a trait of his character. Despite his liberal orientation, whately was rather intolerant of those with whom he disagreed in religious matters. 20 This intolerance, coupled with his incisive skills of argument, alienated many.

Whately was a great talker, much addicted in early life to argument, in which he used others as instruments on which to hammer out his own views. - . He had a keen wit, whose sharp edge often inflicted wounds never deliberately intended by the speaker... With a remarkably fair and lucid mind, his sympathies were narrow, and by his blunt outspokenness on points of difference he alienated many. ${ }^{2}$

Whately's Strengths and Weaknesses

Regularly, whately is described as an intelligent man, and his accomplishments, especially the works on logic and rhetoric, receive high praise. 22 It may be, therefore, surprising to some that, despite his excellent grasp of argumentation and delivery in pulpit discourse, he was not the popular preacher that Hugh Blair had been. 23

${ }^{20}$ Golden and Corbett, p. 275.

$21_{\text {Britannica, }} 11$ th ed., s.v. "Whately, Richard."

22 Encyclopedia Britannica, 11th ed., s.v. "Rhetoric," by R. C. Jebb.

$23_{\mathrm{Bla}} \mathrm{a}$ is considered by some to have been the most popular Scottish preacher of the latter eighteenth cen- 
His sermons were dry, systematic, and unimpassioned. 24

Despite the acuity of his intellect, apparently he was not as wide a reader as some other theorists were. John Stuart Mill said of Whately:

... of all persons in modern times, entitled to the name of philosophers, the two, probably, whose reading was the scantiest, in proportion to their intellectual capacity, were Archbishop Whately and Dr. Brown. But though indolent readers they were both of them active and fertile thinkers. 25

Mill's opinion not withstanding, Whately did read. His favorite authors, and those who influenced him most signficantly, were Aristotle, Thucydides, Bacon, Bishop Butler, Warburton, and Adam Smith. His writings contain many ideas and illustrations drawn from these and other writers. 26

\section{Whately's Works}

According to Lowndes Bibilographical Manual, Whately had ninety-seven published works. 27 His writings covered a

tury. His sermons even today are considered to be models of literary excellence, being concise, clear, and beautiful. F. R. Webber, vol. 2, p. 205.

24 Golden and Corbett, p. 274.

25 John stuart Mill, quoted by Parrish, p. 79.

26 parrish, p. 76.

27 Ibid., p. 78 . 
broad range of topics from theology to economics to the political and social issues of his day. He is best known, however, for his works on logic and rhetoric.

After his return to oxford in 1825, whately wrote rather lengthy articles on logic and rhetoric for coleridge's Encyclopaedia Metropolitana. These articles formed the basis for his best-known writings, Elements of Logic which appeared in 1826 and Elements of Rhetoric which appeared in 1828.28 Each successive edition of the Rhetoric was enlarged and revised, so that by its seventh edition, published in 1846, Parts I and II were more thath two and one half times as large as the original article had been. 29 Both of these works achieved considerable popularity, but the better known of the two is the Elements of Rhetoric.

\section{An Overview of the Elements of Rhetoric}

As indicated above, whately's most famous and influential work is his Elements of Rhetoric. 30 If one wishes to understand his theory of argument in discourse in particular, the study of Whately's Rhetoric is essen-

$$
\begin{aligned}
& { }^{28} \text { Golden and Corbett, p. } 273 . \\
& { }^{29} \text { Ibid., p. } 274 . \\
& { }^{30} \text { Ibid., p. } 273 .
\end{aligned}
$$


tial. 31 Its particular significance for this thesis is in the fact that it is this work which Broadus credited for several of his ideas concerning argument. Therefore, a consideration of the $\underline{\text { Rhetoric }}$ is required for this study. Certain elements will be explained below. First, however, some general observations are in order.

Influences Upon Whately's Elements of Rhetoric

The primary influence upon Whately's theory was the classicist, Aristotle. He also reacted clearly to the theory of his own day, however. That theory included the belletristic notions of Hugh Blair, the elocutionary movement of John Mason, Thomas Sheridan, et al., and the "psychological-epistemological" rhetoric of George Campbell. Ehninger described Whately's negative and positive reaction:

The belletristic, with its tendency to make rhetoric a criticism of written discourse, he rejected out of hand, strongly declaring the proper function of rhetoric to be the supervision of oral composition and in general observing the traditional distinction between the offices of rhetoric and poetry. The elocutionary, with its proclivity toward the prescriptive or "mechanical," he chastened and corrected. Calling elocu-

${ }^{31}$ It should be noted that the term "theory" is used loosely in regard to Whately's work. As Ehninger points out, the Elements is not intended as a theoretical inquiry into the nature of communication. Rather it serves a pedagogical purpose for the instruction of the unpracticed. See Douglas Ehninger, Introduction to Elements of Rhetoric, by Richard Whately (Carbondale: Southern Illinois University Press, 1963), p. xv. 
tionism back from the excesses into which it had fallen, he settled it firmly upon a foundation of unqualified "naturalism," with the tones and manners of earnest conversation as its guiding ideal.

The psychological-epistemological trend whately not only endorsed but, as his major contribution, carried to its logical completion. For while in denying rhetoric an investigatory method of its own Campbell and Priestly had made it exclusively a managerial science, these writers had left unformulated the principles and methods of "management" as they apply in the crucial area of invention.

Accepting the challenge thus posed, whately developed an inventional system aimed at systematizing the selection and application of cogent "reasons," just as the ancients had systematized the process of choosing an appropriate argumentative position and discerning the proofs inherent in it. 32

Whately, then, extended Campbell's ideas concerning logical theory to the discipline of rhetoric. Because, however, he believed that Campbell misunderstood logic he turned often to Aristotle for source materials for both $\operatorname{logic}$ and rhetoric. 33

The Scope of Rhetoric

In whately's view, rhetoric included both written and oral argumentative discourse. 34 Ehninger noted, how-

32 Ehninger, Introduction, p. xxviii.

33 Orville L. Pence, "The Concept and Function of Logical Proof in the Rhetorical System of Richard Whately," Speech Monographs, March, 1953, p. 23. In further citations, this source is called "monograph."

34 orvilie L. Pence, "The Concept and Function of Logical Proof in the Rhetorical System of Richard Whately" (Ph.D. dissertation, University of Iowa, 1946), p. 366. In further citations, this source is called "dissertation." 
ever, that while his system provides for written and oral discourse, the latter is the more prominent.

A second characteristic of the Elements, hardly less important than its theological orientation, is its persistent focus upon the problems and methods of oral argumentation... The Elements, therefore, is not simply to be described as a rhetoric of argumentation. More correctly, it is a rhetoric of oral argumentation--a rhetoric concerned with argument as it occurs either in the formal speaker-audience situation or in the give and take of face-to-face dispute. 35

Important in Whately's work is the view that argument is the primary element of rhetoric. ${ }^{36}$ Although the archbishop discussed style and delivery in his work, the section on argument receives the greatest emphasis. This is undoubtedly the case because whately viewed the finding and arranging or arguments as the only exclusive province of rhetoric.

The finding of suitable ARGUMENTS to prove a given point, and the skilful arrangement of them, may be considered as the immediate and proper province of Rhetoric, and of that alone... The art of inventing, and arranging Arguments is, as has been said, the only province that Rhetoric can claim entirely and exclusively. 37

Ehninger noted the general consensus that whately's emphasis is upon argument.

${ }^{35}$ Ehninger, Introduction, pp. xii, xv.

36 Pence, dissertation, p. 366 .

37 Richard whately, Elements of Rhetoric, with an Introduction by Douglas Ehninger (Carbondale: Southern Illinois University Press, 1963), pp. 39, 40. 
In spirit as in doctrine he holds so consistently to his announced purpose of treating rhetoric as "Argumentative Composition" that even today his work is almost universally--indeed, almost automatically--thought of as a treatise on argument. 38

So pronounced was his view that rhetoric embraces exclusively the whole of oral and written argument that whately is regarded as "the first English rhetorician to treat argument as a separate discipline."39

In believing that the scope of rhetoric is limited primarily to argument, Whately's views coincide with those of the modern authorities Stephen Toulmin and Chaim Perelman. 40 Thus, as Golden asserted, Whately's work ". . is significant both as a historical document and as a moulder of contemporary argumentation theory." 41

${ }^{38}$ Ehninger, Introduction, p. xiv.
${ }^{39}$ Pence, monograph, p. 37 .
${ }^{40}$ James L. Golden, Goodwin F. Berquist, and William E. Coleman, The Rhetoric of Western Thought, 2nd ed. (Dubuque: Kendall/Hunt Publishing Company, 1978), p. 136; cf. Dearin, p. 262-264. It should also be observed that Perelman embraced Whately's notions of presumption and burden of proof, writing, "only change requires justification, presumption playing in favor of what exists, just as the burden of proof falls upon him who wants to change an established state of affairs. Perelman, Justice (New York, 1967), p. 104. Quoted by Ray D. Dearin, "The Philosophical Basis of Chaim Pereleman's Theory of Rhetoric," in Philosophers on Rhetoric, ed. Donald G. Douglas (Skokie: National Textbook Company, 1973), p. 262.

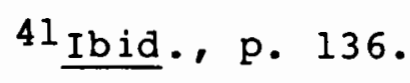


The Relationship of Logic and Rhetoric

Whately's view of the prominence of argument in rhetoric follows from his acceptance of the Aristotelian notion that rhetoric is an offshoot of $\operatorname{logic.42}$ Rhetoric in Whately's view is the art of reasoned discourse, in which "conclusions are inferred from premises according to the laws of logic."43 In rhetoric, the task is to find or invent and arrange suitable arguments to prove a point. In logic, the task is to judge the validity of the arguments. 44 As Pence observed:

The function of logic in Whately's rhetoric was (1) to provide the speaker with a means of evaluating his own thinking to avoid self-deception, and (2) to establish the probability that those ends recommended by the speaker might be reasonably anticipated through the means he proposed.

Logic further serves rhetoric both as a means of ascertaining the truth of rhetorical propositions through investigation and as a means of establishing the truth to the satisfaction of another. In the ascertainment of truth, logic judges whether or not the rhetorical conclu-

42 Britannica, 11 th ed., s.v. "Rhetoric." See also Ehninger's Introduction, p. xii.

43 Ehninger, Introduction, p. xii

44 Whately, p. 40.

${ }^{45}$ Pence, dissertation, p. 366. 
sion reached properly follows the premises given. In other words, it protects one from fallacious argument. 46

In considering the interrelationship of logic and rhetoric, one must not blur the distinctions which Whately observed between the two. As Ehninger points out:

Conceiving of logic as the methodology of proof, he consistently treats rhetoric as the application of that methodology in actual attempts to influence, so that while logic is the process of establishing truth by reasoning, rhetoric becomes the process of conveying truth to others by reasoning. 47

The Purpose or Object of Rhetoric

Rhetoric, in whately's view, functions both to instruct and to convince. Both of these functions are subsumed under his term "Conviction," used in its widest sense. Defining these terms, Whately wrote:

-. under that term [Conviction] are comprehended, first, what is strictly called Instruction; and, secondly, Conviction in the narrower sense; i.e. the Conviction of those who are either of a contrary opinion to the one maintained, or who are in doubt whether to admit or deny it. By instruction, on the other hand, is commonly meant the conviction of those who have neither formed an opinion on the subject, nor are deliberating whether to adopt or reject the proposition in question, but are merely desirous of

${ }^{46}$ Pence, monograph, p. 24. Pence gathered these notions from his study of Whately's Elements of Logic.

${ }^{47}$ Ehninger, Introduction, p. xiv; emphasis mine. 
ascertaining what is the truth in respect of the
case before them. 48

The methods to be used to instruct or to convince are generally the same, although some differences can be noted.

The distinction between these two objects gives rise in some points to corresponding differences in the mode of procedure... these differences however are not sufficient to require that Rhetoric should on that account be divided into two distinct branches; since, generally speaking, though not universally, the same rules will be serviceable for attaining each of these objects. 49

\section{The Ecclesiastical Character of} Whately's Rhetoric

As a further consideration of overview, it must be recognized that the Elements is an ecclesiastical rhetoric.50 The theological illustrations he used, particularly in his treatment of presumption and burden of proof, reflect the fact that whately was a Christian minister, extremely devoted to his Christianity. 51

Following the example of st. Augustine, whately borrowed from the secular to benefit the sacred. Taking from law the notions of presumption and burden of proof, the Archbishop gave the Christian apologist argumentative

48 Whately, p. 36 .

49 Ibid., p. 37.

50 Ehninger, Introduction, p. xix.

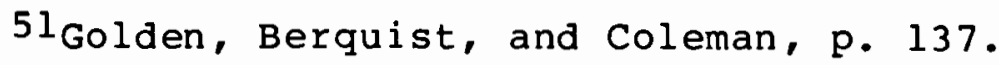


tools to employ in theological controversy. His elements of progressive approach and testimony are particularly useful as arguments for propagating doctrine. 52

Ehninger concisely stated the ecclesiastical usefulness of the work, noting also that the work has 1 imited value for forensic and deliberative purposes.

Throughout the Elements forensic address is scanted, while legislative address is not only ignored but in spirit derogated by whately's class-conscious interpretation of the speakeraudience relationship. From his pages, therefore, rhetoric emerges neither as a method for probing judgments nor as an instrument for arriving at collective choices and decisions. While within limits its services to exegesis are recognized $(36-37)$, its chief business is the justification and propagation of a priori truth; its more particular purposes are (1) to arm the pulpit orator for his task of conveying to an unlettered congregation the indisputable doctrines of the Christian faith, and (2) to arm the Christian controversialist who is called upon to defend the evidences of religion against the onslaughts of the sceptic. 53

\section{Particulars of whately's Theory}

Having discussed Whately's personal background, and having given general description and comments concerning Whately's ideas, the writer turns to the specific elements

52 Ehninger, Introduction, p. $x$, q.v. for other ecclesiastical applications of rhetorical elements. As Golden and Corbett (p. 274) point out, whately's views of the utility of testimony in ecclesiastical discourse are based in his belief in the authority of the Bible.

53 Ehninger, Introduction, p. xi. 
of his rhetoric. A comprehensive review of Whately's theory is beyond the scope of this study. Furthermore, others such as Orville Pence have ably discussed the whole. This writer, therefore, will review only those elements which were original with whately or those common notions which he developed in a significant way.

\section{Arguments from Sign}

Two of the major forms of argument from sign which Whately discussed were argument from testimony and progressive approach. Both of these subjects will be addressed in turn.

\section{Testimony}

One kind of sign argument which whately identified is argument from testimony. He considered it to be a sign not from which a cause could be inferred, but one from which one could infer a condition. In this he was unlike Aristotle, who considered testimony to be an existent rather than an inferred proof. 54 whately justified his difference from Aristotle by describing testimony in terms of premise, conclusion, and condition.

of these last, [i.e., signs which infer a condition which is not a cause] one species is the Argument from Testimony: the premiss [sic] being the existence of the Testimony; the conclusion,

${ }^{54}$ Pence, dissertation, p. 138 . 
the truth of what is attested; which is considered as a "Condition" of the Testimony having been given: since it is evident that so far only as this is allowed, (i.e., so far only as it is allowed, that the restimony would not have been given, had it not been true,) can this argument have any force. 55

Testimony, then, is a sign argument because it reasons from consequence (the testimony) to a condition (that which is testified to).56 If, for example, an individual testified that a particular person robbed a store (this testimony being a consequence), one would conclude that that person robbed the store (that which was alleged in the testimony constituting the prior condition).

The force of such argument is, of course, varied. Testimony does not conclusively prove anything, since it can be falsified. Its own intrinsic character as well as the kinds of conclusions it can support must be considered in weighing its force. 57 However, the relative force of such arguments can be determined along lines whately proposed.

Testimony may concern matters of fact or matters of opinion, a great distinction to whately. The difference between the two is this:

55 Whately, p. 58 .

56 Pence, dissertation, p. 139.

57 Whately, p. 58 . 
-.. by a "Matter of Fact" is meant, something which might, conceivably, be submitted to the senses; and about which it is supposed there could be no disagreement among persons who should be present, and to whose senses it should be submitted: and by a "Matter (or question) of Opinion" is understood, anything respecting which an exercise of judgment would be called for on the part of those who should have certain objects before them, and who might conceivably disagree in
their judgment thereupon. 58

A question of fact must only conceivably be presented to the senses. For a matter to be a fact does not require that it has been presented to the senses. Whately's example explains this notion well, although his moral certainty that no one would ever bear testimony concerning the absence of inhabitants of the moon is today rather humorous.

Whether there is a lake in the centre of New Holland,--whether there is land at the South pole--whether the Moon in inhabited,--would generally be admitted to be questions of fact; although no one has been able to bear testimony concerning them; and, in the last case we are morally certain that no one ever will.5

Often there will be difference of opinion concerning things which are themselves matters of fact. 60 For example, that a witness testified that he saw a particular individual commit a robbery is a fact. Whether or not that witness is a credible source is a matter of opinion.

58 Ibid., pp. $58,59$.

59 Ibid., p. 59.

60 Ibid. 
Conversely, there may be questions of fact relative to opinions. For example, that some economic theorists believe that lower taxes will stimulate the national economy is a well-known fact.

To determine the worth of testimony in a specific case, certain characteristics must be considered. Concerning questions of fact, the honesty of the witness, his accuracy, and his means of gaining information are significant. When an opinion is involved, it is the ability of the witness to form a judgment, or his expertise concerning the subject at hand, that matters. 61

The intellectual character of a witness must be considered in both kinds of cases, and a degree of suspicion must surround any testimony of fact or opinion if the testimony is on the same side as the witness's prejudice. On the other hand, if the testimony runs directly counter to the witness's prejudice, it may be regarded as a stronger testimony. 62

Another factor which will tend to strengthen the force of testimony, assuming other points are equal, is a large number of witnesses. A common mistake in this regard, however, is to think that all witnesses bearing apparently concurrent testimony are actually attesting to

$$
\begin{aligned}
& 61_{\text {Ibid. . pp. } 60,61 .} \\
& 62_{\text {Ibid. . p. } 62 .}
\end{aligned}
$$


the same thing. 63 one person may be attesting to that which he has seen, while one hundred others bear the same testimony based upon hearsay.

These last may indeed have very good ground for their belief: for no one would say that a man who is not versed in Astronomy is not justified in believing the Earth's motion; or that the many millions of persons who have never seen the sea, are credulous in believing, on testimony, its existence: but still it is to be remembered that they are not, in reality, bearing witness to the same thing as the others. 64

Concurrent testimony, however, in cases where the conclusions have been independently derived bears great weight. Such testimony is even more compelling if there is rivalry or hostility among the witnesses. The reason is that if the conclusions are reached separately and if there are rivalries among the witnesses there is far less likelihood of collaboration in a falsehood.65

Concurrence on similar conditions, though leading not to one but rather to similar conclusions, may be significant in establishing a generalization and increasing the probability that a single testimony is accurate. Whately's illustration clarifies his point.

$$
\begin{aligned}
& 63 \text { Ibid. } \\
& 64 \text { Ibid., p. } 63 . \\
& 65_{\text {Ibid., p. } 66 .}
\end{aligned}
$$


Before the reality of aerolites (meteoric stones) was established as it now is, we should have been justified in not giving at once full credit to some report, resting on ordinary evidence, of an occurrence so antecedently improbable as that of a stone's falling from the sky. But if twenty distinct accounts had reached us, from various parts of the globe, of a like phenomenon, though no two of the accounts related to the same individual stone, still, we should have judged his a decisive concurrence; . . because each testimony, though given to an individual case, has a tendency towards the general conclusion in which all concur; ... 66

Testimony is also more credible when it is undesigned. The reason, said whately, is that in such cases the suspicion of fabrication is precluded. His example involves the account of Xerxes's cutting of a canal through the isthmus of Athos. Herodotus's account was ridiculed by Juvenal. But the fact is strongly attested by Thucydides, who made an incidental reference to a place "near which some remains of the canal might be seen."67 Whately attributed great force to the testimony of adversaries, that is, to "all who would be unwilling to admit the conclusion to which their testimony tends."68 Testimony of this type is often incidentally implied due to the reluctance of the witness to bear it. 69

$$
\begin{aligned}
& 66 \text { Ibid., p. } 75 . \\
& 67 \text { Ibid., p. } 63 . \\
& { }^{68}{ }_{\text {Ibid., }} \text { p. } 64 . \\
& { }^{69} \text { Ibid., p. } 65 .
\end{aligned}
$$


In his unwillingness to confirm the truth of a proposition he opposes, an adversary may resort to various forms of evasion. Whately asserts that such tactics serve only to confirm the opposed proposition.

Misrepresentation, again, of argument,--attempts to suppress evidence, or to silence a speaker by clamour,--reviling and personality, and false charges--all these are presumptions of the same kind; that the cause against which they are brought, is,--in the opinion of adversaries at least,--unassailable on the side of truth. ${ }^{70}$

Another matter to consider in evaluating the force of testimony is the probability of that which is asserted. Whately believed that if that which is proposed is unlikely to occur, testimony to its occurrence may be more credible, since it is less likely to have been feigned or fancied. ${ }^{11}$ A witness gains credibility, further, if he does not appear to believe or understand something he is reporting, if it is something the evaluator of the testimony accepts as true, since one is unlikely to fabricate a statement which he himself cannot comprehend. 72

Whately noted that it is generally believed that testimony on oath is more reliable than unsworn witness. He asserted, however, that this is only true of "certain intermediate characters between the truly respectable and

$$
\begin{aligned}
& 7^{70} \text { Ibid.. p. } 68 . \\
& { }^{71_{\text {Ibid. }}} \\
& { }^{72} \underline{\text { Ibid. }}_{\text {I p. }} 69 .
\end{aligned}
$$


the worthless."73 An oath bears significance for the "intermediate" because the worthless sort will sense no constraint against lying, whether he has sworn an oath or not. The truly respectable, on the other hand, "considers himself as, virtually, on his Oath, whenever he makes a deliberate solemn assertion..."74

In his concluding remarks concerning testimony, Whately made the following statement concerning the significance which can be attached to arguments of this type.

It might seem superfluous to remark that none but very general rules, such as the above, can be profitably laid down; and that to attempt to supersede the discretion to be exercised in each individual case, by fixing precisely what degree of weight is to be allowed to the testimony of such and such persons, would be, at least, useless and trifling, and, if introduced in practice, a most mischievous hindrance of a right decision. 75

\section{Progressive Approach}

Another aspect of argument from sign which whately discussed was that of progressive approach. This notion somewhat parallels his idea of concurrent testimony. 76 The notion is that

... several Testimonies or other signs, singly perhaps of little weight, produce jointly, and by

$$
\begin{aligned}
& 73 \text { Ibid., p. } 72 . \\
& { }^{74} \text { Ibid., p. } 73 . \\
& { }^{75} \text { Ibid., p. } 72 . \\
& { }^{76} \text { Pence, dissertation, p. } 155 .
\end{aligned}
$$


their coincidence, a degree of probability far exceeding the sum of their several forces, taken The effectiveness of a series of arguments, according to this idea then, "stems from the order in which they are presented and from their progressive tendency to establish a certain conclusion."78 The procedure is to remove objections encountered in a gradual approach to an inevitable conclusion. 79

\section{Arguments from Example}

Having examined two forms of argument from sign, the writer turns to whately's category of argument from example. In this category, whately included, among others, induction, experience, and analogy. The nature of these arguments is to infer a conclusion about one or more individuals of that class. Whately described it as follows :

- . we consider one or more, known, individual objects or instances, of a certain class, as a fair sample, in respect of some point or other, of that Class; and consequently draw an inference

77 Whately, p. 82.

${ }^{78}$ Ibid.

${ }^{79}$ Pence, dissertation, p. 155. 
from them respecting either the whole class, or other, less known, individuals of it. 80

Whately recognized both the inference from the particular to the general, and from the particular to another particular. The former is obviously inductive; the latter he identified as such because the generalization is implicit.

... [in that] which is the most usually called the Argument from Example, we generally omit, for the sake of brevity, the intermediate step, and pass at once, in the expression of the Argument, from the known to the unknown, individual. This ellipsis however does not, as some seem to suppose, make any essential difference in the mode of Reasoning; the reference to a common class being always, in such a case, understood, though not expressed; . . . 8

With this general overview of Whately's approach to argument from example in mind, the writer turns to one specific type of such argument, namely, argument by analogy

$\underline{\text { Ana logy }}$

Whately, influenced by Campbel1,82 defined an analogy as an argument "in which the instance adduced is somewhat more remote from that to which it is applied." 83 In the

${ }^{80}$ Whately, p. 86.

${ }^{81}$ Ibid.

82 Pence, dissertation, p. 57.

83 Whately, p. 90 . 
case of example (in the Aristotelian sense of reasoning from particular to particular), one draws an inference concerning another individual of like kind. In the case of analogy, the second individual resembles the first to a lesser degree. For instance, if one noticed that a particular drug would poison a man, he might reason from analogy that that drug would also poison a dog. The argument is from analogy in that the dog resembles a man to a lesser degree than another man does. By comparison, an argument from example could only conclude that the drug would poison another man. 84

Whately further defined analogy as a "resemblance of ratios," to use Aristotle's terms. ${ }^{85}$ The likeness of two individuals compared in an Analogy is not in their essence, but in their relation to some other thing or things. Their commonality consists in a relation. 86 He illustrated his point as follows:

- . the fact that from birth different persons have different bodily constitutions, in respect of complexion, stature, strength, shape, liability to particular disorders, etc. which constitutions, however, are capable of being, to a certain degree, modified by regimen, medicine, etc. affords an Analogy by which we may form a presumption, that the like takes place in respect of

84 Ibid.

${ }^{85}$ Ibid.

${ }^{86}$ Ibid., p. 91 . 
mental qualities also; though it is plain that there can be no direct resemblance either between body and mind, or their respective attributes. 87

The analogy given above is in the relation between inborn traits and the possibility of modifying them. In the first particular the traits are physical; in the second they are mental. In the first particular the modifying regimen might be an exercise program; in the second it would probably involve a reading program (or something similar). The analogy is in the relation in both cases of inborn traits and modifying regimens.

Certain errors readily attend this form of reasoning. One common one is that of concluding that the compared individuals are alike because they have a common relation, "to resemble each other in themselves, because there is a resemblance in the relation they bear to certain other things...."88

A related, though separate error is to extend the Analogy further than it was intended. Correctly, whately cautioned against this error in the interpreting of Biblical parables.

In the Parable of the unjust steward, an Argument is drawn from Analogy, to recommend prudence and foresight to Christians in spiritual concerns; but it would be absurd to conclude that fraud was recommended to our imitation; ....89

As whately pointed out in reflecting upon the genius of

$$
\begin{aligned}
& 87 \text { Ibid. } \\
& 88 \text { Ibid. } \\
& { }^{89} \text { Ibid., p. } 92 .
\end{aligned}
$$


the Parables of Jesus as analogical arguments, one may protect his analogies by using images very remote from the thing to be illustrated, except in the single point of intended comparison. One is also wise to use a variety of analogies in making the single comparison, for the thing to be thus illustrated certainly could bear direct resemblance in several points to many diverse analogies. The ultimate test of the validity of an Analogy is to consider in each case not which differences or similarities are the greatest, but which are the ones which do or do not affect the argument. 90

Selection and Use of Arguments

Part I, Chapter III of the Elements of Rhetoric is a discussion of the selection and use of various kinds of arguments. It is in this chapter that whately presents his well-known views concerning presumption and burden of proof.

Major attention is also given to arrangement of arguments, including those used in refuting objections. General notions governing the task of refutation are included, as are observations respecting the problem of excessive proof.

${ }^{90}$ Ibid., p. 102. 
Other matters discussed in the chapter are matters of fact and opinion and the illustrative use of examples. Because these items receive incidental treatment by Whately, and are irrelevant to the larger purpose of this thesis, they will be omitted from this discussion.

\section{The Aim of an Argument}

The first rule governing the selection and use of arguments is to determine the aim or object of the discourse. The possible objects suggested by whately are:

-. to give satisfaction to a candidmind, and convey instruction to those who are ready to receive it, or to compel the assent, or silence the objections, of an opponent. 91

When the chief object is to instruct the learner, the a priori argument will be principally employed. When the object is to refute an opponent, the other class of arguments will be more effective. 92

Presumption and Burden of Proof

Pence, quoting Sandford, asserted that Whately's discussion of burden of proof and of presumption appears to be the first in the history of English rhetoric.93 Not

$91_{\text {Whately, p. } 108 .}$

92 Ibid.., p. 109.

93 W. P. Sandford, English Theories of Public Address 1530-1828 (doctoral dissertation, Ohio State University, 1938), p. 123, cited by Orville Pence, dissertation, p. 175 . 
only was it the first attempt, it was one of the most complete until the twentieth century.94 Although the notion was not unknown in the courts of law, Whately pioneered its application in rhetoric. Particularly evident is his interest in ecclesiastical rhetoric, for in this section of the book he makes several applications to the Christian faith. His ideas on the subject are probably among his greatest contribution to the field of rhetoric at large, for, as Golden asserted, his theory is largely upheld by modern textbooks on argumentation and debate. 95

Determining Presumption and Burden of Proof

At the outset of a case, Whately asserted, after one has determined his aim, he must decide and point out to the hearer on which side the presumption lies and to whom belongs the burden of proof.96 While this might seem to be difficult to determine, Whately noted that "a moderate portion of common-sense" will usually suffice in deciding.

${ }^{94}$ Pence, dissertation, p. 175.

95Golden, Berquist, and Coleman, p. 137. Golden et. al. have prepared an excellent abstraction of presumption and Burden of Proof. On pages 177 and 178 of his dissertation, Pence included quotations from nine different relatively contemporary authors, including Cairns and A. Craig Baird, who adopted Whately's notions in their works on argument and debate.

$$
{ }^{96} \text { Whately, p. } 112 .
$$


The greater problem is that the need to determine the issue is often overlooked.97

Presumption, said whately, has been erroneously been understood by some as referring to a preponderance of probability in favor of the supposition. The Archbishop was careful to point out that, rather, presumption involves:

-. such a pre-occupation of the ground, as implies that it must stand good till some sufficient reason is adduced against it; in short, that the Burden of Proof lies on the side of him who would dispute it.98

Given this definition, a prisoner at his trial is presumed innocent. This does not mean that it is probable that he did not commit the crime, but rather that he pre-occupies the ground of innocence. Those who allege his guilt must displace him from the ground he occupies by proving his guilt. The burden of proof, then, lies with the one who opposes the side which presumption favors.

The presence of presumption on one's side gives him a decided advantage. One in such a position must only refute the arguments brought against him to gain a victory.99 To surrender his pre-occupation of ground is to

$$
\begin{aligned}
& 97 \text { Ibid., p. } 113 . \\
& { }^{98} \text { Ibid., p. } 112 . \\
& { }^{99} \text { Ibid., p. } 113 .
\end{aligned}
$$


abandon that which is perhaps one of his strongest arguments. 100

Examples of Presumption

Whately asserted that there is a presumption in favor of any existing institution, and if one would propose a change in the status quo, the burden of proof lies with him. This does not mean one should assume that existing institutions are perfect; rather, it assumes that change is not a good in itself, and therefore he who demands a change must show cause for it. Furthermore, no one is called upon to defend an existing institution (although it may be advisable to do so) until some argument is adduced against it. 101

There is a presumption against the paradoxical, i.e., anything contrary to the prevailing opinion. To identify a statement as a paradox is not to imply that it is false or absurd. Rather, it means that it is a new statement challenging ground pre-occupied by a prior opinion. The burden of proof rests with he who would maintain the paradox, since men are not expected to aban-

$$
\begin{aligned}
& 100 \text { Ibid., pp. } 113,114 \\
& { }^{101}{ }_{\text {Ibid. }}, \text { p. } 114 .
\end{aligned}
$$


don their present beliefs in favor of new ones without reason to do so.102

Whately illustrated presumption against a paradox from the history of Christianity. Before Christianity was established, the burden of proof rested upon those who affirmed it. After the faith was established, the burden of proof shifted to those who attack it.

It is indeed highly expedient to bring forward evidences to establish the divine origin of christianity: but it ought to be more carefully kept in mind than is done by most writers, that all this is an argument "ex abundanti," as the phrase is,--over and above what can fairly be called for, till some hypothesis should be framed, to account for the origin of Christianity by human means. 103

He selected a second illustration from a period of church history, namely the Reformation. He pointed out that the Reformers bore the burden of proof for the changes in church doctrine they proposed, but were not bound to show cause for maintaining the doctrines they left unaltered. To these latter doctrines they were obligated only to answer objections. 104

Whately also pointed out that regarding any one question, the presumption may lie on different sides, depending upon the biases of the different parties

$$
\begin{aligned}
& 102 \text { Ibid., p. } 115 . \\
& 103_{\text {Ibid. }}, \text { p. } 116 . \\
& 104_{\text {Ibid. }} \text {, pp. } 116,117 .
\end{aligned}
$$


involved.105 For example, at a gathering of the bishops of the Church of England, the presumption concerning a question of infant baptism would be quite different than that at a gathering of Baptist clergy.

Presumption and Deference

Habitual presumption in favor of the decisions or opinions of an individual, a Body, or a book is called "authority." A recognition of authority is called "deference."106 Deference, he said, must be distinguished from admiration, concurrence of opinion, and esteem. One may show deference apart from these three attitudes; and, conversely, one may display the attitudes without deference. 107

Deference ought to be, and usually is, shown selectively. One ought show deference to those who have a reasonable ground for having authority, but only in matters in which they have appropriate expertise. Whately illustrated the point as follows:

One has a deference for his physician, in questions of medicine; and for his bailiff, in questions of farming; but not vice versa. And accordingly, Deference may be misplaced in respect of the subject, as well as of the person. It is conceivable that one may have a due degree of

$$
\begin{aligned}
& 105_{\text {Ibid., p. } 118 .} \\
& 106 \text { Ibid., pp. 118, } 119 . \\
& 107 \text { Ibid., pp. } 119,120 .
\end{aligned}
$$


Deference, and an excess of it, and a deficiency of it, all towards thessame person, but in respect of different points. 108

It is natural, and not unreasonable, to show more deference to the decisions of a group than to those of an individual.109 However, a credible individual's opinion should not be lightly dismissed in favor of a group opinion, for group opinions are often the product of compromise, concession, and exceptions rather than expertise.

Transferring the Burden of Proof

A presumption may be rebutted by an opposite, or counter presumption, thus shifting the burden of proof to the side which had previously enjoyed the presumption. Whately explained how such an exchange takes place.

Again there is... a presumption, (and a fair one, in respect of each question, in favour of the judgment of the most eminent men in the department if pertains to;--of eminent physicians, e. g., in respect of medical questions,--of theologians, in theological, etc....

But there is a counter-presumption, arising from the circumstance that men eminent in any department are likely to regard with jealousy any one who professes to bring to light something unknown to themselves; especially if it promise to supersede, if established, much of what they have been accustomed to learn, and teach, and practise [sic]....

There is also this additional counter-presumption against the judgment of the proficients in

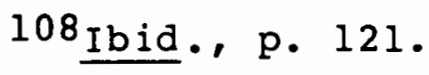

$$
\begin{aligned}
& { }^{109} \text { Ibid.. p. } 123 .
\end{aligned}
$$


any department; that they are prone to a bias in favour of everything that gives the most palpable superiority to themselves over the uninitiated, - . and affords the greatest scope for the employment and display of their own peculiar

In short, the preceding illustration shows that presumption in favor of the learned may be challenged on the grounds of their vain and jealous human character.

Presumption and Advantage

One would naturally expect that it is always an advantage to have presumption in one's favor, and the burden of proof upon the adversary. Surprisingly, the opposite is often the case.11l The reason is that if one enjoys the favor of presumption, he may begin to take a truth for granted. In so doing, he may grow apathetic toward inquiry concerning the subject. In such a state of complacency, he may be jarred by objections raised against his viewpoint. Unable to answer the objections because he has stopped thinking about the issue, he will lose the advantage of presumption, if not the entire argument.

The situation described above finds an analogy in sports. It is often disadvantageous to be favored to win an athletic contest. The favorite may tend to underesti-

$$
\begin{aligned}
& { }^{110}{ }_{\text {Ibid. }}, \text { pp. } 128,129 . \\
& { }^{111_{\text {Ibid. }}}, \text { p. } 129 .
\end{aligned}
$$


mate the opposition, and therefore fail to prepare for the contest properly. Entering the contest with a degree of complacency, the team may be shocked to awareness as the underdog builds a lead. The so-called "momentum" of the contest then favors the challenger, who may hang on to win the contest.

\section{Refutation}

Refutation in whately's schema is treated as a matter of arrangement of arguments, because he believed that the refutation of objections should generally be placed in the midst of the argument.112 The opening of the subject, however, led him a bit afield from arrangement, into a discussion of the conduct of refutation. He knew what he was doing, for he admitted:

Though I am at present treating principally of the proper collocation of Refutation, some remarks on the conduct of it will not be unsuitable in this place. 113

Agreeing with his classical predecessors, Aristotle, Cicero, and Quintilian, whately stated that there is no distinct class of refutatory argument.

In the first place, it is to be observed that there is no distinct class of refutatory Argument;

$$
\begin{aligned}
& 112 \text { Ibid., p. } 146 . \\
& 113_{\text {Ibid. }} \text { p. } 148 .
\end{aligned}
$$


since they become such merely by the circumstances under which they are employed.114

As noted above, whately believed that refutation of objections should be interspersed in the midst of argument, but that it should be done nearer the beginning than the end.115 Particularly if the opponent has advanced many strong proofs so that one's own proposition would be likely to be regarded as paradoxical, one should even begin with a refutation.116 If the previous is not the case, however, one should not begin with a refutation, because that causes him to appear to be on the defensive. To address an objection at the outset, if it is not necessary to do so, implies a consciousness that much can be said against one's assertion, creating an undesirable sense of paradox. ${ }^{117}$

Mention of objections should not all be deferred to the end of the discourse, however.

If again all mention of objections be deferred till the last, the other arguments will often be listened to with prejudice by those who may suppose us to be overlooking what may be urged on the other side.118

$$
\begin{aligned}
& 114 \text { I bid.. p. } 148 . \\
& 115 \text { Ibid., p. } 146 . \\
& 116 \text { Ibid. } \\
& 117 \text { Ibid.. p. } 147 . \\
& 118 \text { Ibid. }
\end{aligned}
$$


Therefore, because to address all objections at the outset will create an impression of paradox and to save them until the end will diminish the hearing one will receive, objections normally should be addressed in the midst of the discourse.

Sometimes, it is difficult to refute objections sufficiently until one has established through argument his own propositions. In such cases, whately urged that at least brief notice of the objections be taken early in the discourse, carefully including a promise to refute them later.119 such a promise, however, should not be used as sophistical evasion of objections difficult to answer. The Sophist will promise to refute the objections, but will in the presentation of his own case draw the listener's attention away from the objections. Conveniently, he will forget to answer the objections, which will then not be given their due weight. 120 Whately asserted that any proposition may be refuted by proving its opposite or by overthrowing the arguments by which it has been supported.121 The first of these two, he said, is less strictly to be considered refutation,

$$
\begin{aligned}
& 119 \text { Ibid. } \\
& 120 \text { Ibid. } \\
& 121_{\text {Ibid., p. } 148 .}
\end{aligned}
$$


because it can exist apart from one's awareness of a proposition counter to his own.

The former of these is less strictly and properly called Refutation; being only accidentally such, since it might have been employed equally well had the opposite Argument never existed; and in fact it will often happen that a proposition maintained by one author, may be in this way refuted by another, who had never heard of the Arguments. - . In fact, every one who argues in favour of any Conclusion is virtually refuting, in this way, the opposite conclusion. ${ }^{122}$

Following the pattern of Aristotle and Cicero, 123 Whately said that refutation in its strict sense involves a reference made and an answer given to some specific arguments in favour of the opposite conclusion. This refutation may consist in the denial of the premises (either the stated or implied premise in an informal syllogism) or in an objection against the conclusiveness of the reasoning. 124

Whately distinguished between direct and indirect arguments in refutation. The direct approach proves the truth of the contradictory by handing the objections from the opposite perspective. With the indirect method, one attempts to prove the absurdity or falsity of another's proposition using his own premises. 125 This form of refuta-

122 Ibid.

123 Pence, dissertation, p. 208.

124 Whately, p. 149 .

125 Ibid., p. 150. 
tion could also be called reductio ad absurdum. Whately described the approach and its usefulness as follows:

... in Controversy, the Indirect is often adopted by choice, as it affords an opportunity for holding up an opponent to scorn and ridicule, by deducing some very absurd conclusion from the principles he maintains, or according to the mode of arguing he employs. Nor indeed can a fallacy be so clearly exposed to the unlearned reader in any other way. For it is no easy matter to explain, to one ignorant of Logic, the grounds on which you object to an inconclusive argument; though he will be able to perceive its correspondence with another, brought forward to illustrate it, in which an absurd conclusion may be introduced, as drawn from true premises. 126

Whately, with his bent toward satire, said more in favor of this form of refutation, citing as an illustration of it his attack on scepticism in "Historic Doubts."

The dangers of this kind of "irony," as he called it, are two. First, many listeners fail to differentiate between the form and the substance of the argument. Consequently, when they hear one using ridicule with a serious (or in the case of an ecclesiastical application, a sacred) subject, they believe that he is profaning the subject. The second danger is that when one applies a good title, for example, to someone in bitter scorn, he may appropriate the title to himself in a serious sense, and thus diffuse the irony. 127 For example, one may be

$$
\begin{aligned}
& 126 \text { Ibid., pp. 150, } 151 . \\
& 127 \text { Ibid., pp. 154, } 155 .
\end{aligned}
$$


labeled as "orthodox" in scorn, the label implying that his views are anything but orthodox. He may ignore the satire intended and appropriate the label seriously, creating the impression that his adversary has conceded that his views are orthodox.

Whately continued his section on refutation by explaining its limitations.

It may be observed generally, that too much stress is often laid, especially by unpractised reasoners, on Refutation;... I mean, that they are apt both to expect a Refutation where none can fairly be expected, and to attribute to it, when satisfactorily made out, more than it really accomplishes. 128

The first limitation is that, when the propositions with which one works are matters of probability, irrefutable arguments may be advanced against a proposition that is nevertheless true. He described the problem and its solution as follows:

In what is called moral or probable Reasoning, there may be sound arguments, and valid objections, on both sides... The real question in such cases is, which event is the more probable;-on which side the evidence preponderates.... The objection perhaps may be unanswerable, and yet may safely be allowed, if it can be shown that more and weightier objections lie against every other supposition. 129

The preceding assumes that the counter-arguments are valid. of course, all are not.

$$
\begin{aligned}
& { }^{128} \text { Ibid., pp. } 155,156 . \\
& { }^{129} \text { Ibid., p. } 156 .
\end{aligned}
$$


Secondly, men may believe that successful refutation of all the arguments offered in support of a conclusion disprove the conclusion. The conclusion, however, may be true. The false assumption operative in this case is that all the possible arguments in favor of the conclusion have been presented (and subsequently refuted).130 That all possible arguments were not advanced may be the unfortunate failure of a weak advocate. In such a case, it is regrettable that the whole argument falls for want of a competent advocate.131 on the other hand, however, the advocate may purposefully have reserved certain arguments as whately recommended subsequently.

Because a weak argument is "positively hurtful," Whately urged that objections be stated with their full force when refuting them.132 The reason is this:

-... otherwise, those who hear them stated more strongly than by the uncandid advocate who had undertaken to repel them, will naturally enough conclude that they are unanswerable. 133

To state the objection weakly is to appear to be avoiding its difficulty.

$$
\begin{aligned}
& 130 \text { Ibid. } \\
& 131 \text { I p. } 158 . \\
& 132 \text { Ibid. } \\
& 133_{\text {Ibid. }} \text { p. } 159 .
\end{aligned}
$$


When objections raised are not only unanswerable, but also are decisive, whately urged that an advocate confess the fact and abandon his argument. To refuse to retract an untenable position is unwise, for such refusal is likely to cast suspicion on that which is sound in the advocate's position.134 At stake in such a situation is the advocate's credibility.

Whately also warned against elaborately refuting insignificant arguments. To pay great heed to an inconsequential argument will frequently have the effect of elevating its importance. The Archbishop explained and illustrated his point as follows:

Whatever is slightly noticed, and afterwards passed by with contempt, many readers and hearers will very often conclude (sometimes for no other reason) to be really contemptible. But if they are assured of this again and again with great earnestness, they often begin to doubt it. They see the respondent plying artillery and musketry,--bringing up horse and foot to the charge; and conceive that what is so vehemently assailed must possess great strength. One of his refutations might perhaps have left them perfectly convinced:
doubt.
35

Refutation is directed toward fallacious premises or reasoning processes. Therefore, a complete study of refutation includes a discussion of logical fallacies.

$$
\begin{aligned}
& 134 \text { Ibid. } \\
& { }^{135} \text { Ibid., p. } 161 .
\end{aligned}
$$


Whately acknowledged the need for consideration of the subject, but did not include such a discussion in his Rhetoric. Instead, he referred his readers to Book iii of his Elements of Logic. 136

The possibility of excess in refutation led whately to warn regarding the danger of excess in proof as well.

others, again, perhaps comparatively strangers to the question, and not prejudiced, or not strongly prejudiced, against your conclusion, but ready to admit it if supported by sufficient arguments, will sometimes, if your arguments are very much beyond what is sufficient, have their suspicions roused by this very circumstance. "Can it be possible," they will say, "that a conclusion so very obvious as this is made to appear, should not have been admitted long ago?". . . Hence they are apt to infer, either that the author has mistaken the opinions of those he imagines opposed to him, or else, that there is some subtle fallacy in his arguments. ${ }^{137}$

In situations, however, in which forcible proofs are desired, one may find it necessary to caution the hearers against thinking that a point is difficult to establish, simply because its importance led one to dwell upon it. 138 Whately supported his point with an example and an analogy.

Some e.g. are apt to suppose, from the copious and elaborate arguments which have been urged in defence of the authenticity of the christian

$$
\begin{aligned}
& 136 \text { Ibid., p. } 150 . \\
& 137 \text { Ibid., p. } 163 . \\
& 138 \text { Ibid., p. } 162 .
\end{aligned}
$$


Scriptures, that these are books whose authenticity is harder to be established than that of other supposed-ancient works; whereas the fact is very much the reverse. . We bar the doors carefully, not merely when we expect an unusually formidable attack, but when we have an unusual treasure in the house. 139

Whately concluded his discussion of refutation by noting the difference between simply disproving an error and showing how it arose. While the former should be sufficient to dislodge an argument, he said, the latter will effect greater satisfaction and a more lasting result. 140

\section{Whately's Contributions to Rhetoric}

The purpose of this chapter has not been to critique Whately's theory of argument, but rather to expound selected portions of it. It would be presumptious for this writer to attempt independently an assessment of the Archbishop's work. The opinions of a few individuals, qualified by their formal study of rhetoric in general and Whately in particular, will suffice to summarize whately's contributions.

Perhaps his most significant contribution was that of introducing the notions of presumption and burden of

${ }^{139}$ Ibid.

140 Ibid., p. 167. 
proof, known in both Roman and English law, 141 into the world of rhetoric. As Golden, Berquist, and Coleman wrote:

It is difficult to overestimate the importance of Whately's pioneering analysis of presumption and burden of proof. What makes his discussion a significant landmark in the rhetoric of Western thought is the reminder that presumption rests not on the side where a "preponderance of probability" exists, but on that side which consists of a "preoccupation of the ground." (i.e. that side which the majority of a given audience favors at the outset of a speech.) And he was also on target in reminding his students that no meaningful debate on a controversial question can proceed intelligently unless it is first determined where the presumption lies. Finally, whately contributed vitally to argumentation theory when he pointed out that, in most circumstances, there is a presumption in favor of "existing institutions," "innocence," "tradition," and people who command "deference." 142

These same authors noted a second major contribution made by whately and others of his day, namely, a psychological, audience-centered rhetoric grounded in the nature of man. 143 Much of the Archbishop's practical advice, particularly that relating to refutation, is conditioned by his analysis of the way an audience can be expected to perceive one's argument. Clearly his interest was not only in establishing the truth of a proposition, but also in making it convincing to the hearer. Pence developed

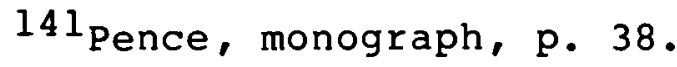

142 Golden, Berquist, and Coleman, p. 142. 143 Ibid., p. 143 . 
this contribution nicely as follows:

But his originality is best seen in his perceptive analyses of the techniques of refutation and in his intensive study of fallacies. These are characterized by a useful integration of the logical with the psychological elements of persuasion. He was most aware that an argument must be credible as well as logical... His special skill lay in his ability to clarify obscurities in intricate argument--to conduct a searching exploration of the open ground between the purely formal logical errors and the psychological errors of

Pence asserted that Whately's "careful distinction between arguments from example and arguments from analogy is unmatched in English rhetoric."145 Besides noting that analogies compare relationships whereas examples compare concrete qualities, Whately established helpful criteria for judging the validity of these two types of argument.146 His explanation of the nature of arguments from probability and from sign removed much of the obscurity of Aristotle's discussion of these elements.147

Pence, writing in 1946, reached the following conclusion concerning the contemporary usefulness of Whately's work:

-.. Whately was not a learned logician, in a philosophical sense. But few, if any, figures in the

${ }^{144}$ Pence, monograph, p. 38 .

145 Ibid., p. 37.

146 Ibid., p. 38 .

147 Ibid. 
history of English rhetoric to his time matched his application of the principles of sound reasoning and hard common sense to argument. His practical application of probability as a rationale for action in human affairs, his introduction of burden of proof into rhetoric, his insistence on precision in the use of terms, and his comprehensive treatment of fallacies in general are reflected in virtually all treatises argument since his time.148

Ehninger observed that when the modern field of Speech was born near the turn of the twentieth century, Whately's ideas were embraced by the leaders in the new discipline. He also noted its continuing influence when he wrote in $1963:$

-. for many years the instruction given in courses and textbooks in public address has been, and remains today, strongly whatelian, while only recently have such theorists as Kenneth Burke and I. A. Richards begun to envision new functions and boundaries for rhetoric as a discipline.

Because Whately's decisions on some of the major questions in rhetoric have proved sound and fruitful through many years of practice, the Elements, while not to be numbered among the great creative works on the subject, is certainly to be ranked among the most influential. For the same reason, though now a century and a third old, it has much to say to the student of rhetoric yet today.

Nearly a century earlier, John Broadus had recognized the worth of Whately's theory. It is to whately's influence upon this American homiletician that the next chapter is addressed.

${ }^{148}$ Pence, dissertation, pp. $380,381$.

149 Ehninger, Introduction, p. xxx . 


\section{JOHN BROADUS'S THEORY OF ARGUMENT}

The preceding chapter provided some personal background of Richard Whately, together with an exposition of his theory of argument. In this chapter, the same kind of information will be presented regarding John Broadus. First the writer will develop a brief survey of his life. Then an overview of his theory of argument will be presented, followed by a more particular analysis of Broadus's ideas and the influence of Richard whately upon them .

\section{Background of John Broadus}

W. O. Carver, a younger contemporary of John A. Broadus, stated that in his opinion, "no Baptist of his generation surpassed Broadus in his influence among Southern Baptists." Broadus wielded such influence not because he occupied positions of power within the denomi-

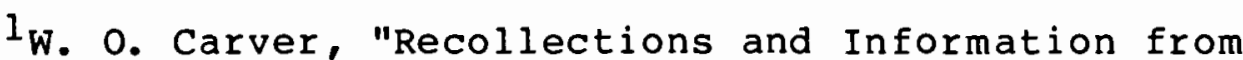
other Sources Concerning The Southern Baptist Theological Seminary," unpublished typescript, p. 2l, cited by James Roland Barron, "The Contributions of John A. Broadus to Southern Baptists (doctoral dissertation, Southern Baptist Seminary, 1972), p. 1 . 
nation, but because his scholarly learning, his compelling preaching, and his personal charm commanded broad popular respect.

One has only to read briefly concerning the life of Broadus to discover how highly he was regarded, and why he was held in such esteem. A brief chronology of Broadus's life will enable the reader to understand Broadus's impact upon American preaching.

\section{A Chronology of His Life}

The Broadus family was prominent in the early history of the "Old Dominion," Virginia.2 The Broaduses were, for the most part, farmers. However, there were physicians, lawyers, many teachers, and ministers, some of them men of great distinction. They were profoundly religious, almost all members of country Baptist churches in Virginia. 3 Into this family, John Albert Broadus was born in Culpeper county on January $24,1827.4$

John's father was Major Edmund Broadus, said to be a

2A. T. Robertson, Life and Letters of John A. Broadus (Philadelphia: American Baptist Publication Society, 1901), p. 1 .

3W. J. McGlothlin, "John Albert Broadus," The Review and Expositor 27 (Apri1, 1930): 141; Cf. Robertson, p. 3 .

${ }^{4}$ Robert N. Barrett, "Dr. John A. Broadus," The Seminary Magazine 8 (April, 1895): 339. 
man of high character, ability, and independence of judgment. 5 Edmund was a farmer, miller, teacher, major in the Culpeper militia, a member of the virginia legislature for eighteen years, and a leader of the whig party in the state. 6 He was an ardent supporter of Thomas Jefferson in the founding of the University of Virginia in 1819.7

John's mother was Nancy Simms, a woman of many excellent qualities. She was gentle and quiet in manner, yet firm and energetic in the management of her home. ${ }^{8}$ Her husband's frequent absence due to his political activity made it necessary for her to run the family farm, which she did with great efficiency. With her children, she was a firm but gentle disciplinarian, teaching them habits of neatness and order. 9

Because there were no public schools, as we know them, John received his preparatory schooling privately. He undertook his secondary school studies with his uncle, Albert Simms. Simms was reputedly one of the best teachers in the area, and as a result, young Broadus

\footnotetext{
${ }^{5}$ McGlothlin, p. 142 .

6 Ibid.

${ }^{7}$ Ibid., p. 143.

${ }^{8}$ Robertson, p. 17.

${ }^{9}$ Ibid., p. 18 .
} 
received an excellent secondary education. 10 John was an excellent student, particularly in Latin and mathematics. During his last year at his uncle's school, John assisted in the instruction. 11

At the age of seventeen, Broadus became a country school teacher. Although the experience was difficult and discouraging for him, due to his youth, 12 he persisted in the endeavor, developing in the process the teaching skills and habits of hard and independent work which characterized his later life.13 Broadus's success in life, according to Robert Barrett, was not due to brilliant achievement, but to "patient, quiet, humble industry."14

In the fall of 1846 , Broadus enrolled at the University of virginia in Charlottesville, where he was profoundly influenced by Gessner Harrison, professor of Greek, W. H. McGuffey, professor of moral philosophy, and H. H. Courtenay, professor of mathematics. ${ }^{15}$ His irregular course of study kept him at the university two years longer than most students. However, Dr. W. J. McGlothlin,

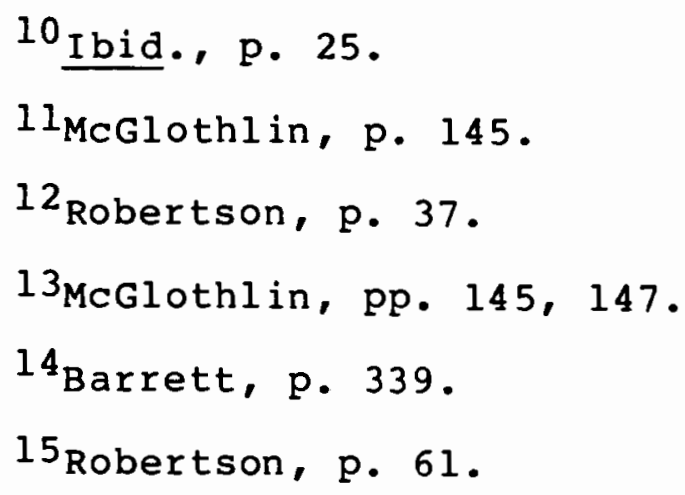


a former president of Furman University and a colleague of Broadus at Southern Seminary, noted that by the time he graduated in 1850 , Broadus was regarded as the leading student scholar there.16

Within a year of his graduation from the University at the age of twenty three, Broadus was ordained to the ministry, married to the daughter of Gessner Harrison, appointed an assistant professor of Latin and Greek at his alma mater, and called to the pulpit of the charlottesville Baptist Church. 17 In 1853 he resigned from the University to devote his full attention to the church, but in 1855 he was persuaded to return as chaplain to the University. He remained in this role until 1857 when once again he returned to his pastorate. 18 While serving the church he also served the University indirectly, for his preaching attracted both students and professors, as the following statement by a student, George B. Taylor, indicates.

Pressed as he was with double duty, his preaching reached high water mark, and the little Baptist church at Charlottesville was always crowded, the

${ }^{16}$ MCGlothlin, p. 152. Robertson made similar comments, citing the opinions of Prof. F. H. Smith and Hon. $w$. W. Henry who was a fellow student, on pp. 65 and 74 of Life and Letters of John Albert Broadus.

${ }^{17} \mathrm{Clyde}$ E. Fant, Jr., and William M. Pinson, Jr., Twenty Centuries of Great Preaching, vol. 5: MacLaren to Talmadge (Waco: Word Books, Publisher, 1971), p. 43.

${ }^{18}$ Ibid. 
congregation including numbers of the students and often professors as well. Never can I forget how I would sit enwrapped in his eloquence which was scarcely surpassed afterwards, however much he may have grown. 19

In the mid-50s the Southern Baptist Convention began seriously to consider forming a seminary in the south. Broadus was among the five young men to whom the Convention turned for leadership in the venture. 20 To him fell the lot of developing a plan of organization and instruction. That which he devised was heavily patterned after the model he had learned at the University of virginia. The plan was described and assessed by McGlothlin as

\section{follows :}

When the committee reported at Greenville in 1857 , they proposed a new type of theological seminary, based largely on the plan of the University of virginia, one with emphasis upon the English Bible, with freedom for the student in the selection and pursuit of studies, with the highest scholarship for the able and prepared students and with something worth while for all. The plan proposed by the committee was adopted and while it has had some drawbacks, it has justified itself and has exercised a profound influence upon theological education throughout America. It was half a century and more in advance of most of the theological institutions of the country. 21

In 1859 Broadus was persuaded to give up his church and join the founding faculty of the Southern Baptist

${ }^{19}$ George B. Taylor, "Virginia Baptist Ministers," unpublished manuscript, cited by Robertson, p. 106.

20 McGlothlin, p. 156.

${ }^{21}$ Ibid., p. 157 . 
Seminary in Greenville, South Carolina.22 It was to the work of the seminary that he devoted the remainder of his 1 ife.

The seminary's small beginning, with four faculty members and twenty-six students, was soon to be tested by the advent of the Civil war. Enrollment declined to the point that, in the fall of 1862, the school had too few students to open. 23 The closure of the school was a disappointment to Broadus, but it also provided for him the opportunity to preach in various churches and to begin labor on one of his finest works, his commentary on the Gospel of Matthew. 24

The Civil War also presented Broadus with the opportunity to serve as a chaplain in the Confederate armies. J. William Jones, D. D., related the following story, recounting how the opportunity arose.

In the early spring of 1863 I was walking one day from our camp at Hamilton's Crossing, near Fredericksburg, Virginia, to old "Round Oak" Baptist Church, some eight miles off, when, hearing the clatter of horses' hoofs behind me, I turned and saw the familiar form and face of "Stonewall" Jackson mounted on his famous "Little sorrel1."

As he drew near he recognized me, asked if I was going to the meeting of the Chaplains' Association, and dismounting walked with me for several miles, talking about the religious interests of his men, and the best means of reaching them.

22 Barrett, p. 340 .

23 Robertson, p. 196 .

24 Ibid. 
Among other things he said that he would like to see some of the ablest preachers of all the denominations come to the army, if not as permanent chaplains, at least as missionaries for a time. He mentioned the names of a number of leading men whom he would be especially glad to have come, and among them Dr. J. A. Broadus, saying very earnestly: "Write to him by all means and beg him to come. Tell him for me that he never had a better opportunity of preaching the gospel than he would have right now in these camps"...

When I met General Jackson a few days after the reception of Dr. Broadus's letter, and told him that he would come, the great soldier said, in his characteristic phrase: "That is good--very good. I am so glad of that. And when Dr. Broadus comes you must bring him to see me. I want him to preach at my headquarters and I wish to help him in his work all I can." Alas! the battle of Chancellorsville came on a few days afterward, and before the great preacher could see the great soldier Stonewall Jackson had "crossed over the river to rest under the shade of the trees." 25

Following the Battle of Gettysburg, Broadus maintained an active preaching schedule, drawing large crowds of soldiers from the hospitals and camps.wherever he went.26 one high point of his war-time preaching occurred on Confederate Fast Day, when he spoke at General Gordon's headquarters. An'immense crowd--probably 5,000 in number-gathered to hear Broadus preach. Several Confederate generals attended the meeting, among them Robert E. Lee, A. P. Hill, Ewell, and Early. 27

$25 \mathrm{~J}$. William Jones, "As Evangelist in Lee's Army," The Seminary Magazine 8 (April, 1895): 353, 354.

26 Ibid.

27 Ibid., p. 357. 
After the war, the Seminary reopened, but times were difficult in the impoverished south. Determined to see the institution succeed if at all possible, Broadus and his colleagues reopened the school on November 1,1865 , with seven students. Broadus had only one student in homiletics, and that student was blind. But so careful was he to prepare thoroughly to teach his single student that his lectures became the basis for his Treatise on the Preparation and Delivery of Sermons. 28

The Seminary continued to struggle financially, unable to raise an adequate endowment due to the state of the southern economy. Broadus and his colleagues regularly visited churches and individuals to solicit funds to stabilize the institution. Broadus had several opportunities which would have offered greater financial security, 29 but he refused them, determined to honor his commitment to southern. 30

Broadus continued in his duties during the seventies and eighties, teaching Greek and Homiletics. During this

\section{Robertson, p. 214 .}

${ }^{29}$ Ibid., p. 306. Brown University, Crozer Seminary, Richmond College, the First Church, Richmond and Eutaw Place, Baltimore all sought Doctor Broadus's services at a time when there was not enough money to pay the salaries of the professors.

30 Ibid., pp. 281,282. In 1877 the school was moved to Louisville, Kentucky where it eventually was to become more secure financially. 
period his reputation as a preacher increased so that he was in demand in churches of many denominations, in many cities, and for various types of meetings. 31 Bothered by frail health and exhaustion, he found it necessary at times during this period of his 1 ife to reduce his responsibilities so that he could recover. One such occasion occurred in 1870, at which time he received the following note from none other than Robert E. Lee.

LEXINGTON, VA., June 21, 1870: I am glad to learn that you have decided to visit Europe, and trust complete relaxation from duty and the objects of interest that will at all points attract your attention, may entirely restore your health, and that you will return renovated in strength and vigor, to 32 ladden the hearts of your many friends. 32

In 1889, upon the death of his colleague and friend of over thirty years, president J. P. Boyce, Broadus was appointed president of Southern Baptist Seminary. ${ }^{33}$ As president, Broadus gathered a faculty of young men to assist his aging faculty and to ensure the future of the seminary at the turn of the century. 34 He also worked

31 Ibid., p. 316. Among these speaking engagements were several addresses to the Southern Baptist Convention, the 1889 Lyman Beecher Lectures at Yale, speeches at universities, church dedications, etc.

32 Ibid., pp. 403, 404.

33 Fant and Pinson, p. 43.

${ }^{34}$ Robertson, pp. 402,420 . 
to increase the endowment 35 and built buildings to house the institution. 36 He reduced some of his teaching and speaking responsibilities as well so that he could devote significant time to writing projects he hoped to complete in his sunset years. 37

For the last year of his life he suffered ill health. He preached his last sermon in the summer of 1894. That fall he taught as he was able, but it was obvious that his strength was failing. He died on March 16 th, 1895.38

Characteristics of the Man

The preceding chronology has hinted at some of Broadus's characteristics, because they were so manifestly intertwined with the events of his life. Those characteristics and others will now be discussed briefly.

One of Broadus's outstanding qualities was his pleasantness and charm. ${ }^{39}$ This characteristic enhanced his stature with people throughout his 1 ife. 40 It was probably

${ }^{35}$ Ibid., p. 406.
${ }^{36}$ Ibid., pp. $398,414$.
$37_{\text {Ibid. . pp. } 403,404 .}$
$38_{\text {Robertson, p. } 422 .}$
$39_{\text {McGlothlin, p. } 159 .}$
$40_{\text {Robertson, pp. } 17,18 .}$ 
this quality which contributed to his persuasive power in the Southern Baptist Convention, although he held no formal denominational office. 41 It also, no doubt, accounts for his popularity in the North, although he was a loyal southerner. Dr. W. H. Whitsitt wrote:

He was loyal to his section. He kept his feet always firmly planted on Southern sod. He was the idol of the Confederate Veterans who have come to stand with sad pride in the order of his funeral. Yet he was as much loved in New York as in Virginia. Whatever he spoke from any platform on ei ther side of the line was applauded to the echo on both sides of the line. Other men have endeavored to accomplish a feat of that sort and have often failed ingloriously. ${ }^{42}$

Broadus's charm was attested to by many, but perhaps the most eloquent statement was made at his funeral by Rabbi Adolph Moses.

He was the most charming and brilliant conversationalist I have known. He touched on no subject but he adorned and illumined it. Whatever the subject of conversation, he opened large and new vistas to the surprise and delight of his admiring friends. However trite and stale the topic, he lifted it to a higher plane. There was a play of fine humor and wit in his talk. But he never employed the weapon of sarcasm or irony. He never abused his great intellectual powers in debate. ... There was such touching gentleness in his voice, such noble modesty in his demeanor that it was a pleasure to bow to his superiority. He was an excellent listener. He was all attention and

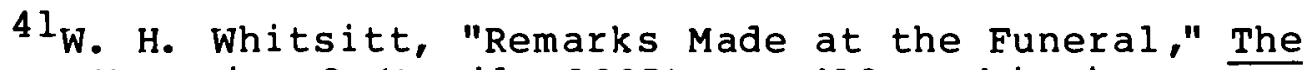
Seminary Magazine 8 (April, 1895): p. 413. Whitsitt called him"... for thirty years the leading force in our Southern Baptist Convention..."

$$
42 \text { Ibid., p. } 412 \text {. }
$$


eagerness to hear what one had to say. . . He greeted the most ordinary persons with gracious cordiality and utmost respect. . . Broadus was an ideal American gentleman. He was perhaps the most amiable and lovable southerner of his time. 43

Broadus's scholarly interests have been noted above, in part. He was a wide reader, with interests in history, biography, poetry, and fiction. Concerning languages he was a scholar of Greek and Latin, he knew Anglo-Saxon, Hebrew, and Coptic well, was at home with French and German, and had some knowledge of Italian, Gothic, and Sanskrit. 44 In addition to his seven books, he wrote many tracts, pamphlets, and magazine and journal articles for publications such as the Homiletic Review. 45

As a popular preacher, Broadus had few peers. Over the course of his life, he preached at least 2,187 sermons, 1,274 of them itinerantly.46 He served as pastor for seven churches over the course of his career, and also spent several summers preaching in the churches. $47 \mathrm{He}$ preached at the Southern Baptist Convention at least

43 Rabbi Adolph Moses, "As a Conversationalist," The Seminary Magazine 8 (April, 1895): pp. 382, 383.

${ }^{44}$ A. T. Robertson, "As a Teacher," The Seminary Magazine 8 (April, 1895): 360 .

45 I bid., pp. 364-366.

46 Jerry Paxton Ashby, "John Albert Broadus: The Theory and the Practice of His Preaching" (doctoral dissertation, New orleans Baptist Theological Seminary, 1968), p. 17 .

47 Barron, p. 167 . 
eleven times between 1863 and 1891.48 His preaching was popular, although his substance was disarmingly simple and his delivery reserved by the standards of the day. ${ }^{49}$

One critic, a prominent pastor in virginia who preferred a grandiloquent delivery to Broadus's conversational style, charged him with ruining Southern Baptist preaching. 50 Although Broadus was not without his critics, the majority of them commended him very highly. His excellence is affirmed by Dr. W. C. Wilkinson of the University of Chicago, a man not much given to superlative praise. 51

I have named in my title a man with every natural endowment, every acquired accomplishment, except, perhaps, plenitude of physical power, to have become, had he been only a preacher, a preacher hardly second to any in the world.

A conjectural judgment like the foregoing, it is, to be sure, almost always unwisely bold and hazardous to put forth. I simply record the impression which, after some familiarity acquired with the man himself, seen and heard both in public and in private, and after no little conversance with his productions in print, I find fixed and deepening in my mind concerning Dr. Broadus. 52

48 Ibid., p. 177 .

49 Edgar E. Folk, "As a Preacher," The Seminary Magazine 8 (April, 1895): 374 .

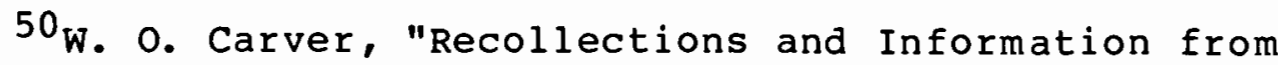
Other Sources Concerning the Southern Baptist Theological Seminary," cited by Barron, p. 181.

$51_{\text {Edgar Dewitt Jones, The Royalty of the Pulpit }}$ (New York: Harper and Brothers Publishers, 1951), p. 51.

52 w. C. Wilkinson, Modern Masters of Pulpit Discourse, p. 344 , cited by Jones, p. 51 . 
Vernon L. Stanfield, himself a professor of preaching and the man who undertook the 1979 revision of Broadus's Treatise, wrote:

During the last half of the nineteenth century in America, no Baptist preacher enjoyed greater popular fame than did John Albert Broadus. By his Seminary colleagues, by denominational leaders, by competent critics of preaching, and by appreciative congregations, he was ranked as one of the leading preachers of his time. 53

other characteristics could be noted concerning Broadus, but perhaps the most striking of all was the depth of his Christian character and fervor. Perhaps the best attestation to Broadus's Christianity came from his Jewish friend, Rabbi Moses.

Before I became familiar with Dr. Broadus I knew Christianity only as a creed which seemed absolutely incomprehensible to me. I judged it mainly from the untold, unmerited misery, the agony of ages which Christian rulers and nations had entailed upon poor Israel under the impulse given by Christian priests and teachers. But when I learned to know and revere in Broadus a Christian [sic], my conception of Christianity and my attitude toward it underwent a complete change. Broadus was the precious fruit by which I learned to judge of the truth of Christianity. 54

53 Vernon L. Stanfield, Favorite Sermons of John A. Broadus (New York: Harper and Brothers Publishers, 1959), p. 1.

${ }^{54}$ Rabbi Adolph Moses, quoted by McGlothlin, p. 160. 


\section{An Overview of Broadus's Theory}

Broadus's Treatise on the Preparation and Delivery of Sermons has long been recognized as a fine textbook for the training of preachers. W. C. Wilkinson, whose following statement may be considered as typical of the opinion of many, affirmed the excellence of the work.

The individual opinion of the present writer is that, fairly judged in view of the whole round of its comparative merits, the volume of which I now speak is not only one of the best works, but by eminence quite the best work of its kind in existence for the use of the average English reader and student. There may be writers on homiletics who surpass Dr. Broadus in suggestive originality of view, there may be those who surpass him in profoundness of formal philosophy, there may be those who surpass him in elegance of exposition; but if I were asked to name a writer on homiletics who, equalling him in the union and harmony of these different traits, moreover equalled him in alert sagacity of insight, in sure sobriety of judgment and of taste, in breadth and comprehension of treatment, in sympathetic and penetrative Christian tone and spirit--and it has been my duty to read somewhat widely in the literature of homilectics [sic]--I should be obliged to confess myself unable to do it. 55

\section{Broadus's View of the Relation \\ of Rhetoric and Preaching}

Historically, preaching was distinguished from the secular discourse of such men as Demosthenes and Cicero.

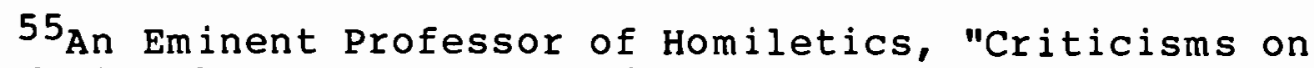
Some of the Ablest Representative Preachers of the Day," The Homiletic Review 16 (August, 1888): 100. This eminent professor is identified as W. C. Wilkinson by $A$. T. Robertson in Life and Letters of John A. Broadus,

p. 367 . 
While the secular followed a certain formal arrangement, the homily was considered to be a talk, or a familiar discourse. 56 st. Augustine was probably the first to bring the secular and sacred together in his book, On Christian Doctrine, Book IV. In this fifth century work, Augustine pressed many classical rhetorical notions into the service of preaching. Perhaps more significantly, however, he prepared the way for viewing preaching as a kindred art, if not a branch, of rhetoric. 57

Broadus believed that preaching is a kindred art of rhetoric insofar as the fundamental principles of both relate to common human nature. To the extent that this commonality exists, then, homiletics may be regarded as rhetoric applied to a particular kind of speaking. Preaching differs from secular discourse, according to Broadus, in the primary source of its materials, its directness and simplicity of style, and the unworldly motives which should influence the preacher and his presentation. 58

56 John A. Broadus, Treatise on the preparation and Delivery of Sermons, ed. E. C. Dargan (New York: Hodder and stoughton, 1898), p. 15 .

57 Ibid.

58 Ibid., p. 16. For Broadus, the primary source of preaching material was the Bible. preaching style should be clear to any listener, motivated by a compulsion to speak a message from God for the good of the hearer. 
Because he accepted the overlap of preaching and rhetoric, it is not surprising that Broadus urged his readers to study works on rhetoric. Included in his list of such works are Aristotle's Rhetoric as well as the writings of Cicero and Quintillian. He also recommended the reading of several more contemporary works, among them Campbell's Philosophy of Rhetoric. of particular significance for the present study is his commendation of Richard Whately's Elements of Rhetoric. Concerning Whately's volume he wrote:

Nor has Whately's admirable "Rhetoric" been rendered valueless by more recent discussions. Its treatment of Argument and Style is particularly good. 59

\section{Broadus's View Concerning the Place of Argument in Preaching}

The assumptions regarding the rational nature of the Christian faith which undergird whately's use of argument in preaching comport well with Broadus's views on the subject. Broadus the scholar certainly knew that mere assertion was insufficient to convince a doubter that

59 Broadus, p. 544. In the 1870 edition of his Treatise, p. 32, Broadus said, "Whately's Rhetoric is believed to be the best treatise for practical use that has appeared. Especially valuable are the portions on Argument and on style." In Dargan's revision, this comment was revised as quoted and placed in a bibliography at the end of the book. At the end of his life, Broadus maintained that more recent discussions had not rendered Whately's "admirable work" valueless. 
one's proposition is true. His opinion of the importance of the subject is evident in the extent to which he dis-

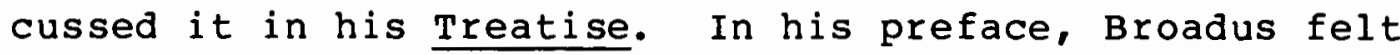
compelled to explain his extensive treatment of argument. He wrote:

The subject of Argument is thought by some to be out of place in a treatise on Homiletics or on Rhetoric in general. But preaching and all public speaking ought to be largely composed of argument, for even the most ignorant of people constantly practice it themselves, and always feel its force when properly presented; and yet in many pulpits the place of argument is mainly filled by mere assertion and exhortation, and the arguments employed are often carelessly stated, or even gravely erroneous. 60

Although he regarded argument in preaching highly, he realized that a good thing can be overdone. In his chapter on explanation, he cautioned against the overuse of argument. He stated that preachers often belabor arguments when the need is for practical and simple explanations. 61

In his materials on argument, the influence of Whately is unmistakable. While some notions are elaborated from other sources, almost every element of argument Broadus proposed is also found in whately's Rhetoric. Broadus accounted for the influence of whately as follows: The author's chief indebtedness for help has been to Aristotle, Cicero, and Quintilian, and to

$$
\begin{aligned}
& { }^{60} \text { Broadus, p. xi. } \\
& { }^{61_{\text {Ibid. }}} \text { p. } 153 .
\end{aligned}
$$


Whately and Vinet. The two last (together with Ripley) had been his text-books,--and copious extracts are made from them on certain subjects. 62

One of the subjects to which Broadus undoubtedly referred was argument, for he confessed:

The well-known chapters of Whately have been here freely employed, but with very large additions, and with the attempt to correct some important errors. 63

Considering the substance of Broadus's confession, quoted above, an investigation should disclose many similarities in their respective approaches to argument. It should also reveal some differences between the two men. It is to the relationship of the two theories that the writer will turn below.

\section{A Summary of Broadus's Materials} Concerning Argument

Before developing the comparison of whately and Broadus, the writer will preview Broadus's chapter on argument. The basis of the preview and the analysis to follow, organizationally, will be the 1898 revision of the Treatise, done by Broadus's associate and successor, Dr. E. C. Dargan. The revision was chosen instead of the original because while the substance remained essentially

$$
\begin{aligned}
& 62 \text { Ibid., p. xii. } \\
& 63 \text { Ibid., p. xi. }
\end{aligned}
$$


unaltered, the organization of thought is easier to follow in the later work. 64

Chapter VII of Broadus's Treatise is entitled "Special Materials--Argument." The chapter is divided into seven sections. Section one deals with the importance of argument in preaching. Section Two concerns questions preliminary to argument, including the matters of presumption and burden of proof. Sections Three and Four are a treatment of principal varieties and forms of argument. Section Five is a discussion of refutation. The sixth section involves the subject of arrangement, and the seventh includes some general suggestions governing argument.

All of the elements of argument named above will not be reviewed here. To consider all of them would lengthen this study unduly. However, those elements of Broadus's

${ }^{64}$ This choice will not compromise the necessity of studying a primary source, even though it is a revision. By revising the book, Dargan was carrying to completion Broadus's own plan to revise it. Prior to his death, Broadus had discussed the revision with Dargan, who had become his associate at the Seminary in 1892. Certain revisions Broadus had penciled into his notes, others he and Dargan specifically discussed, and a few were made by Dargan with the consent of Broadus's family. See E. C. Dargan, Preface to the Revised Edition of Treatise on the Preparation and Delivery of Sermons (New York: Hodder and stoughton, 1898), p. vii. The 1870 and the 1898 texts have been compared and no differences bearing upon this study were discovered. It seems reasonable to assume that any changes recorded in the 1898 edition reflect changes in Broadus's ideas during the mature years of his career. 
theory which clearly reflect whately's major contributions, as discussed in the second chapter, are treated below.

\section{A Comparison of the Theories of Whately and Broadus}

The purpose of this section is to outline and expound selected ideas concerning argument set forth in Broadus's Treatise, and to compare them to those of Richard Whately, whose theories were explained in the previous chapter. As indicated above, the ideas discussed are those which reflect Whately's influence in the areas of the his most significant contribution to the understanding of rhetoric. The assumption that direct reference to whately or the inclusion of similar ideas constitutes influence was stated in the first chapter. It must be admitted that similar ideas might be attributed to a source common to both men rather than to whately. If Broadus's wording is similar to Whately's, however, it is reasonable to assume that whately was his source.

It should also be noted at the outset that Broadus's section on argument is not nearly as complex as Whately's. It is therefore assumed that Broadus included what he considered to be the most important of Whately's elements, together with ideas from other theorists, as they related to his purpose of writing a homiletics textbook. Although 
he borrowed ideas from others as well, Broadus relied most heavily upon whately, "whose discussion on Arguments," he said, "is the most valuable part of his work on Rhetoric, and unequalled by other treatises." Besides including a number of Whately's principles, in some places Broadus also used his illustrations. 65

It should be noted, finally, that in those elements which Broadus borrowed from whately, he was in substantial agreement with the Archbishop. Only in the matters of presumption and burden of proof did Broadus take exception to the Englishman's views.

\section{Questions Preliminary to Argument}

As matters preliminary to the framing of an argument, Broadus identified three questions, all of which reflect the influence of Whately. These involve the placement of the proposition, the determination of the burden of proof, and the value of presumption in argument. For purposes of this study, the latter two subjects will be discussed.

Burden of proof

Concerning burden of proof, Broadus both agreed and disagreed with whately. Although some matters of agree-

$65_{\text {Broadus, p. } 172 .}$ 
ment may be found, Broadus pointedly emphasized the areas of disagreement. 66

First, Whately said that it is important to determine at the outset where the burden of proof lies. 67 Unlike the Archbishop, Broadus said that the preacher is only indirectly concerned with the burden of proof. The notion is more useful in legal proceedings and in debate. Regarding controversial sermons, however, Broadus conceded that placement of the burden of proof is essential. At such times, he said, it is wise to make formally clear to the hearers where the burden 1 ies. 68

Second, Broadus accepted the Roman legal formula for determining the burden of proof, which he paraphrased, "He who alleges anything must prove his allegation; and, conversely, no man is required to prove the negative of another man's assertion."69 If, however, one asserts a

66 In what is probably a veiled reference to the Archbishop, Broadus said, "On this subject, certain very erroneous views have lately obtained currency, from a confusion of two different senses of an ambiguous term." John Broadus, Treatise on the Preparation and Delivery of Sermons, 14 th ed. (New York: A. C. Armstrong \& Son, 1889), p. 163. Curiously, this statement is omitted in the Dargan revision, although Broadus's ideas on the subject remained unchanged.

${ }^{67}$ Richard Whately, Elements of Rhetoric, ed. Douglas Ehninger (Carbondale: University of Southern Illinois Press, 1963), p. 112.

68 Broadus, p. 174 .

${ }^{69}$ I bid. 
negative, he is obligated to prove it, for the burden of proof always rests with the one who alleges. Because it is difficult to prove a negative proposition, seldom are assertions made in negative form. 70 contrary to the Roman notion which Broadus adopted, Whately asserted that the burden of proof rests upon the side opposite the one favored by presumption. 71 To whately, then, the placement of the burden of proof depended upon the determination of presumption in each given case, a matter which will be discussed more fully below. To Broadus, presumption and burden of proof were separate matters, the former being irrelevant to the determination of the latter.

\section{Presumption}

Broadus did not consider presumption to be particularly pertinent in preaching, although he advocated a clear understanding and fair use of the principles involved. 72 This fact is due in part to his views on the related matter of burden of proof, which he believed was pertinent only in controversial speaking. It is also, no doubt, the consequence of his views concerning the nature of presumption.

\footnotetext{
$70_{\text {Ibid., pp. } 174,175 .}$

$71_{\text {Whately, p. } 112 .}$

72 Broadus, p. 175.
} 
Broadus distinguished three different meanings of the notion of presumption. These he called the common meaning, the legal usage, and Whately's definition. ${ }^{73}$ The common meaning, as he understood it, is this:

A presumption in favor of any proposition is, in the most general statement, something which inclines us to believe it true before examining the proof, or independently of any formal process of reasoning. In other words, it is that part of the evidence which lies upon the surface and leads to the belief in advance of further investigation. -. in itself, strictly and etymologically speaking, a presumption is that which we take hold of before we enter formally into investiga-

It is evident that the strength of presumption will vary from person to person. One may confront a proposition with a strong presumption, while an opponent has little or no disposition in its favor. For example, a person who attends church regularly would probably confront a proposition asserting the existence of God with a strong presumption favoring the proposition. An atheist, on the other hand, would consider the same proposition with no disposition in its favor. The speaker, therefore, must be aware of his audience's viewpoint in each case, for presumption is situational. 75

${ }^{73} \underline{\text { Ibid. . p. } 176 .}$

74 Ibid.

${ }^{75}$ Ibid. 
The legal sense of presumption is an arbitrary determination framed in the interest of justice. Its best known expression is that an individual accused of a crime is presumed to be innocent until he is proven guilty. As a matter of fact, the actual logical presumption is often the exact opposite, as demonstrated in the lawful arrest of a suspect. A warrant is issued on the practical, logical presumption of guilt, but the trial proceeds on the legal, arbitrary presumption of innocence. Broadus asserted that legal presumptions should not confuse the issue in moral reasoning where the arbitrary, benevolent principles of law are not in question. 76

Broadus observed that whately defined presumption in a way which departs from both the common and the legal uses of the term. He quoted Whately's definition, which rejects the notion of preponderance of probability in favor of a proposition, considering presumption instead to be the preoccupation of ground.77 Actually, as he developed his notion of preoccupation, whately embraced both the legal and common meanings which Broadus preferred to distinguish. The Archbishop's examples of preoccupation included presumption of innocence in courts of law, one aspect of the legal meaning. He also believed that

76 Ibid. p. 177.

77 Ibid. Cf. Whately, p. 112 . 
presumption can be a function of audience prejudice, remarking that in any one question the presumption will often be found to lie on different sides in respect of different parties. 78 This notion is clearly like unto the common meaning endorsed by Broadus.

For Whately, presumption and burden of proof were inextricably linked. If a proposition is favored by presumption, the burden of proof rests with the other side. Broadus separated the two elements, noting that they depend on different principles. Broadus conceded that presumption in one's favor might strengthen his argument, but it doesn't transfer the burden of proof to the opponent as Whately asserted. Burden of proof, Broadus affirmed, always rests upon the one who alleges. 79

To clarify the difference of viewpoint, we may consider as an example the matter of baptism. The proposition to be argued is that the church should practice infant baptism. Whately would say that presumption favors the proposition, because historically in the Church infants have been baptized. Broadus would deny the validity of presumption upon the basis of institutional precedent. He would say that, apart from the context of an audience, presumption cannot be determined. Whately

$78_{\text {Whately, p. } 118 .}$

${ }^{79}$ Broadus, pp. $177,178$. 
would assert that the burden of proof rests upon the one opposing infant baptism, for the burden rests upon one who disputes the position favored by presumption. Broadus would argue that the burden of proof rests upon the one asserting the proposition that infants should be baptized, for to place the burden upon the opponent would require him to prove a negative, namely, that infants should not be baptized. If the proposition were made to an Anglican audience, Broadus would say presumption strengthens the argument, but it would not determine the placement of the burden of proof.

If the proposition were that the church should baptize only those who profess faith, both theorists would say that the burden of proof rests with the one asserting the proposition. Their reasons, however, are different. Whately would say that the burden rests upon the one making the assertion, because his proposition is contrary to the view enjoying the advantage of presumption. Broadus, on the other hand would place the burden on the same individual, reasoning that he who alleges must prove. If the audience were Anglican, Broadus would concede that presumption is against the proposition, and this fact should be considered in the development of argument. The burden of proof would rest upon the proponent, not because 
the pedobaptist 80 viewpoint preoccupies the ground, although it would with the given audience, but because the one who alleges must prove.

If the audience were a Baptist audience, Broadus would probably acknowledge the benefit of presumption in favor of the proposition, but would still place the burden of proof upon the one asserting the proposition. Whately would face a dilemma in this situation. On one hand, his view that presumption favors existing institutions would lead him to conclude that presumption opposes the proposition at hand and that the burden rests with its proponent. On the other hand, his statement that audience prejudice may determine presumption would lead him to conclude that presumption favors the proposition, since the audience bias of Baptists is toward baptism of only those who profess faith. The burden of proof would then rest with the opponent of the proposition.

It is evident that Broadus preferred the common meaning of presumption when the application was to pulpit rhetoric. The legal use he confined to courts of law, insisting upon a distinction between the law and moral reasoning. Whately's meaning did not distinguish legal and common uses. Furthermore, it included some other conditions, such as the favoring of existing institutions,

80 Pedobaptism is the baptism of infants. 
which the Archbishop believed established preoccupation of ground. Broadus rejected Whately's approach as unproven and unreasonable. 81

\section{Principal Varieties of Argument}

of five principal varieties of argument presented by Broadus, four reflect the influence of whately. Those four types are argument a priori, argument from induction, argument from analogy, and argument from testimony. The latter two will be discussed below.

\section{Argument from Analogy}

The influence of whately is evident and extensive in Broadus's treatment of argument from analogy. Mill and Campbell are each cited once, but clearly whately was the predominant influence as far as this variety of argument is concerned.82 Except as noted, each of the ideas discussed below clearly follows whately's theory.

Broadus cited Whately's notion that analogy is not to be confused with resemblance, but rather refers to

${ }^{81}$ Ibid.. pp. 174-178. This discussion of Whately's line of reasoning is the basis for the inference that Broadus found whately's views unreasonable.

82 In fact, in the reference to Mill, Broadus takes exception to the former's notion that arguments from analogy are invalid because objects called analogous are similar in some respects but dissimilar in others. See Broadus, p. 193. 
proportion. 83 Noting the confusion of many concerning the nature of this form of argument, he wrote:

Analogy is still too often confounded with resemblance, notwithstanding the earnest efforts of Whately and some other writers to confine the term to its original and proper sense. 84

He illustrated the notion of proportion, using three examples. One of these examples was that of the likeness between an egg and a seed as the 1 ink between a parent bird and its nestling in the one case and the old plant and the seedling in the other. This illustration was taken directly from whately. 85

Because two objects may be analogous in one relationship, it must not be presumed that the analogy extends to all of their relationships. When reasoning by analogy, one must be careful not to extend the analogy beyond its proper limits. Broadus employed Whately's illustration of this rule as he wrote:

Thus, because a just analogy has been discerned between the metropolis of a country, and the heart of the animal body, it has been sometimes contended that its increased size is a disease,--that it may impede some of its most important functions, or even be the cause of its dissolution. ${ }^{86}$

${ }^{83}$ Broadus, p. 192 ; cf. Whately, pp. $90,91$. 84 Ibid.

85 Ibid., pp. 192, 193; cf. Whately, p. 91. 86 Ibid., p. 194 ; cf. Whately, p. 92. 
In the example above, the diseased enlargement of the animal heart is improperly used to allege that it is undesirable for a city to become large, and that the fatal consequences of an enlarged heart will also occur in the case of a large city.

One difficulty with argument from analogy is the frequent similarity of analogous objects. Such similarity often results in erroneous comparison of the resemblance rather than the corresponding ratios. Because of this difficulty, the proper points of analogy are often clearer when the objects do not resemble each other. ${ }^{87}$ Although Whately had not stated this notion explicitly, it is very evident in his work. Based upon this premise, he explained that several of Jesus' parables are very remote from the point to be illustrated, except in the one essential to his message. ${ }^{88}$ This remoteness prevents an interpreter of the parables from making unintended analogies from details of the story involved.

Broadus wrote concerning the usefulness of examples invented to furnish argument, considering such to be arguments from analogy. 89 Aristotle had written of the distinction between real and invented examples, so that one

87 Ibid., pp. 192, 193.

88 Whately, pp. $92,93$.

${ }^{89}$ Broadus, p. 197. 
might conclude that Broadus was in this case influenced more by the Greek than by the Englishman. This, however, does not appear to be the case. Whately, citing Aristotle, referred to real and invented examples. However, unlike Aristotle who believed that the real example was the more convincing, Whately asserted that a supposed case, if it is probable, will often be no less convincing than the real.90 Broadus apparently adopted Whately's view, for he said that merely probable cases may provide an analogy which will be highly convincing. With this idea he credited whately in a footnote. 91

Finally, Broadus observed that real and invented examples, used as analogical arguments, are sometimes used not as proof, but rather to explain or make an argument interesting.92 In this he clearly followed whately, who had said that this variety of argument may be used at times not to prove anything, but either to illustrate and explain one's meaning or to amuse the fancy with the ornament of language. 93

Broadus included a few other ideas, such as the usefulness of arguments from analogy to refute objections,

90 Whately, p. 103.

91 Broadus, p. 197; cf. Whately, pp. 103, 104. 92 Ibid.

93 Whately, p. 108 . 
which do not appear in Whately's text. However, the major elements he discussed reflect the unmistakable imprint of Whately.

\section{Argument from Testimony}

The next principal variety of argument Broadus discussed is that of argument from testimony. Departing from Whately, he pointed out that the words "testimony" and "authority" are often confused. The former, he believed, should be applied only in matters of fact. The latter should be used concerning matters of judgment or opinion. 94 At the same time, he cited Whately's premise that men are inclined to confuse facts with their judgments concerning them. 95

As had Whately, Broadus stated that in testimony to matters of fact, the character and number of witnesses will either strengthen or weaken the argument.96 A wit-

94 Broadus, pp. 197, 198. See also whately, p. 61, where, in a footnote, the Archbishop acknowledged that testimony to matters of opinion usually was designated "authority." In his Elements of Logic he confirmed this as the primary sense of the term, calling it a claim to deference. Richard whately, Elements of Logic (London: Longman, Green, Longman, Roberts, and Green, 1864), p. 194. However, in his discussion of argument from testimony in his Rhetoric he preferred to speak of testimony regarding matters of fact and regarding matters of opinion.

95 Ibid., p. 198; cf. Whately, pp. 58-61.

96 Broadus, p. 199; cf. Whately, p. 61. 
ness's truthfulness, intelligence, and opportunity to know the facts are primary considerations. Whately's development of these notions is far more thorough. It is evident from a footnote that Broadus expected his readers to refer to Whately for a more complete discussion of the subject. 97

A large number of witnesses to a common fact will strengthen an argument from testimony if the witnesses' knowledge was gained first-hand, rather than from what others have told them.98 Details of individual testimonies may differ, but will not invalidate the testimony as long as these details are non-contradictory. In fact, noncontradictory discrepancies among their accounts serve to authenticate the independence of the witnesses and to strengthen their combined testimony to the substantial facts. 99 Broadus used this notion as an argument to defend the authenticity of the Gospel accounts of the life of Christ.

The unintentional testimony of adversaries is a compelling argument. Broadus barely mentions this, apparently assuming that his readers would consult whately

97 Ibid., p. 202. Broadus referred his readers to pp. 78-104 in whately, which corresponds to pp. 58-76 in the Ehninger edition.

98 Ibid., p. 199; cf. Whately, pp. 61, 62.

${ }^{99}$ Ibid. 
for a thorough treatment. His illustration, that the miracles of Jesus were acknowledged by unbelievers, makes the allusion to Whately unmistakable. 100

Concerning the character of things attested, Broadus noted that the improbable requires more testimony to gain credence than does the probable. In this regard, he discussed the miracles of Jesus as examples. Miracles are improbable and therefore can be expected to require more testimony to establish their credence. The testimony of Jesus, strengthened by arguments for his sterling character, and the witness of others are offered by the Gospel writers as arguments affirming the actual occurrence of the miracles. 101

It has been demonstrated that Broadus closely followed whately in relating testimony to matters of fact. His dependence upon the Archbishop is evident not only in the similarity of ideas, but also in the footnote mentioned above. However, he related authority rather than testimony to matters of opinion.

Broadus made a distinction between testimony and authority. The early Church Fathers, for example, offered testimony concerning the apostolic origin of the New

${ }^{100}$ Ibid., p. 200; cf. Whately, pp. 64-66. ${ }^{101}$ Ibid., pp. 200,201 ; cf. Whately, p. $68 \mathrm{ff}$. 
Testament documents. Their interpretations of the meaning of those documents, however, is a matter of authority.102

Broadus also believed that the Bible should be considered in a discussion of testimony and authority. His views concerning the authority of the Bible are essential to understanding his approach to establishing the proof of a proposition. For Broadus, a Biblical affirmation was the supreme argument, as the following statement indicates :

The Scriptures themselves are an authority indeed. All that they testify to be fact is thereby fully proven, all that they teach as true and right is thereby established and made obligatory. There are some subjects on which the Bible is our sole authority, such as the Trinity, justification by faith, the conditions of the future life, and the positive ordinances of Christianity; namely, baptism and the Lord's supper. The Christian reasoner should seek fully to appreciate this unparalleled authority, and should heedfully observe its proper relation to all other means of
proof. 103 Although this notion is not developed in whately's discussion of argument from testimony, it is consistent with that which he said concerning the presumption and deference established in favor of the decisions or opinions of "an individual, a body, or a book."104 It also is consistent with the Archbishop's view that the Bible alone is

102 Ibid., pp. $202,203$. ${ }^{103}$ Ibid., p. 203. ${ }^{104}$ Whately, p. 118, emphasis mine. 
the religion of Protestants. As Golden and Corbett noted, it was his allegiance to the Scriptures that accounts for Whately's emphasis on testimony in his Elements of Rhetoric. 105

To summarize, Broadus identified five principal varieties of argument. His ideas were not original, but were conventional. Although other theorists were quoted, Whately was the predominant influence upon Broadus's ideas. Accurately summarizing this section of Broadus's

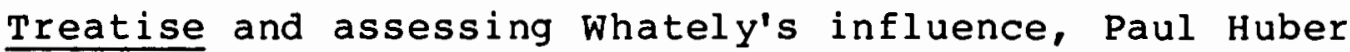
wrote:

Broadus presents no unusual definitions in his development of the principal varieties of argument. Most of his material comes from his study and work in the area of argumentation. He does admit, however, that he was influenced by whately, and it is evident that his views closely parallel those of the English Archbishop. 106

Forms of Argument

Broadus next discussed five forms of argument.

These included argument a fortiori, progressive approach, dilemma, reductio ad absurdum, and ex concesso. His treatment of the forms is brief, and in

105 James L. Golden and Edward P. J. Corbett, The Rhetoric of Blair, Campbell, and Whately (New York: Holt, Rinehart and Winston, Inc., 1968), p. 274.

106 paul Huber, "A Study of the Rhetorical Theories of John A. Broadus" (doctoral dissertation, University of Michigan, 1956), p. 23. 
each case conforms to standard definitions. The progressive approach will be discussed here, since it is this form only which reflects whately's influence.

The argument from progressive approach involves proof based upon a progressive tendency toward substantiation of the point in question. Broadus attributed this idea to whately, who described it as involving the collective force of several arguments which individually considered would have little weight. By presenting a series of such arguments in optimum order, he said, one can establish a progressive tendency toward a certain conclusion. 107

Broadus illustrated the form with an argument regarding the development of religious tolerance. He borrowed the example from whately and abbreviated it as follows:

In every age and country, as a general rule, tolerant principles have (however imperfectly) gained ground wherever scriptural knowledge has gained ground. And a presumption is thus afforded that a still further advance of the one would lead to a corresponding advance in the other. 108

\section{Refutation}

Broadus recognized that often the assertion of counter propositions is not sufficient to prevail in establishing one's viewpoint. The arguments of an oppo-

107 Whately, p. 82.

${ }^{108}$ Broadus, pp. 205,206 ; cf. Whately, pp. 84,85 . 
nent must be met, and objections to one's own arguments must be addressed. Although the preacher may not have an actual antagonist, he must be aware of contrary arguments which he must refute if he would convince his audience that his proposition is correct. 109 So that his readers might be more skillful, Broadus included eight principles which govern refutation of arguments. These will be discussed below.

First, Broadus noted that proving the opposite truth is a sufficient refutation of error.110 In this view he agreed with Whately, who had observed that a proposition may be refuted either by proving its opposite or by overthrowing the arguments in its favor.lll

Second, in moral reasoning, one cannot al ways fully refute all arguments. This is due, in part, to the fact that moral reasoning deals in probablilities rather than in empirirical data. Furthermore, some arguments are too weak to refute. If one cannot see their absurdity, he will probably not be persuaded by the best refutation.112

An inability to refute an argument will not necessarily weaken one's own position. Broadus stated that the

$$
\begin{aligned}
& 109 \text { Ibid., p. } 207 . \\
& 110_{\text {Ibid. }} \\
& 111_{\text {Whately, p. } 148 .} \\
& 112_{\text {Broadus, pp. } 208,209 .}
\end{aligned}
$$


reason for believing any moral truth consists in considering the arguments in favor of it, minus the objections refuted as far as possible.113 In support of this notion he quoted whately, who had asserted that an unanswerable objection may be allowed if weightier objections can be presented against every other supposition.114 Included also is whately's illustration concerning evidences of religion, which suggested that rather than answering every objection to Christianity, one should pose the possibility of human origin of the Christian faith and then determine which proposition bears the fewer difficulties. 115

Broadus's third principle is that when objections are discussed, they should be stated in full force.116 in other words, one should state his opponent's objection as accurately and strongly as possible rather than making a straw man of the objection. Although the straw man may be more easily destroyed, such refutation is hardly persuasive to those who understand the force of the objection. Although Broadus did not quote whately as his source for this idea, it parallels Whately's statement very closely.

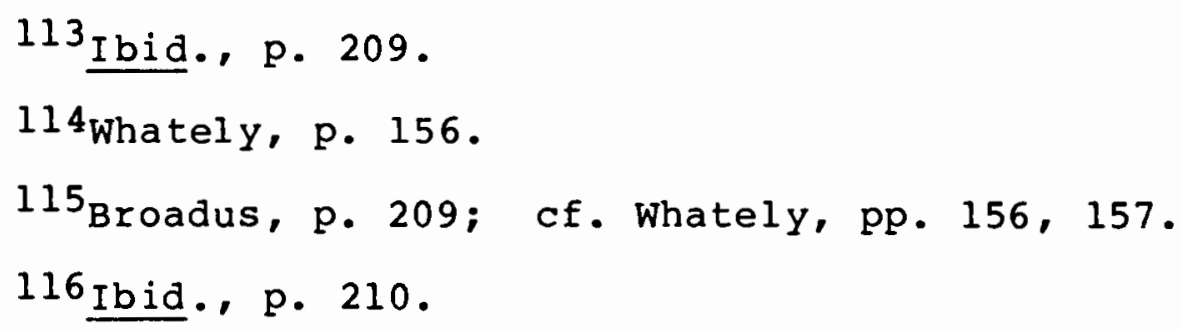


The Archbishop encouraged the statement of objections in full force lest the audience conclude that they are unanswerable. 117

Fourth, Broadus identified four aspects of an argument to which refutation may be directed. The four are named in his following statement:

Refutation, whether of an erroneous proposition, or of an objection to the truth, will be accomplished by showing either that the terms are ambiguous, the premises false, the reasoning unsound, or the conclusion irrelevant. 118

Broadus developed his idea with quotations from Potter and vinet, who were contemporary writers on the subject of homiletics. His thoughts, however, were not unlike those of Whately, who had noted that refutation may consist either in the denial of one of the premises of the argument or in objection to the conclusiveness of the reasoning. 119

Fifth, Broadus suggested that refutation is strengthened if the origin of an error can be shown. To illustrate the principle, he referred to infant baptism. His argument was that after one deals with any New Testament passages offered in support of the practice, one can further refute it by tracing its origin to the second or

\footnotetext{
117 Whately, pp. 159, 160 .

$118_{\text {Broadus, p. } 210 .}$

119 Whately, p. 149.
} 
third century. 120 whately also asserted that even if an argument has been decisively refuted on other grounds, the case against it will have a longer lasting effect if the error is traced to its origin.121 Perhaps Broadus borrowed the idea from whately, but he certainly did not find his illustration in the Archbishop's work!122

Sixth, Broadus urged the use of indirect refutation, the principal variety of which is reductio ad absurdum. This argument form is used to reduce an opponent's argument to absurdity. For example, it might be proposed that a particular tragic story be censored from the newspaper because it might create emotional distress for readers. Following that line of reasoning, one could argue in refutation that no bad news should be published because it might promote distress. Broadus developed relatively extensively the notion of indirect refutation with an extensive and unmistakable dependence upon whately.123

one kind of indirect refutation is to show that an opponent's premise proves too much, i. e., that besides the conclusion drawn, it proves one that is inadmissable.124

\footnotetext{
120 Broadus, p. 211 .

$121_{\text {Whately, p. } 167 .}$

122 Anglicans practice infant baptism.

123 Three footnotes cite whately.

124 Broadus, p. 212; cf. Whately, p. 151.
} 
Another type is irony, with which one makes an opponent or an error appear to be ridiculous.125 Because some will complain that irony is irreverent, Broadus counseled that it be used sparingly in sermons. ${ }^{126}$ The third kind is the sophistical method which consists in counter-objections urged against something taken to be, although it is not, the only alternative. Broadus included one of Whately's examples, in which a man replies to the censure he receives regarding a vice to which he is addicted that there are other vices which are worse.127

Broadus's seventh principle is that refutation should not be too elaborate or vehement. His reasons clearly reflect his dependence upon whately for this notion, for he said that excessive strength of refutation

125 Broadus illustrated the notion from the Biblical story of the prophet Elijah who confronted the prophets of Baal on Mt. Carmel. After his opponents had unsuccessfully called upon their god, Elijah taunted them, saying, "Call out with a loud voice, for he is a god; either he is occupied or gone aside, or is on a journey, or perhaps he is asleep and needs to be awakened." Broadus, p. 212. Whately illustrated this idea by referring to his pub1 ished Historic Doubts, which with irony attacked the scepticism of David Hume. Whately, p. 152-155.

\section{Broadus, p. 213.}

127 Ibid.; cf. Whately, p. 157. Specifically, Whately said that if he is blamed for being a sot, he dilates on the greater enormity of being a thief, as if it were necessary that he be either. 
will arouse deep-seated prejudices and may prompt one to cling to the refuted argument as a matter of pride.128 Eighth, Broadus observed that successful refutation gains the sympathy of the hearers, often to their detriment, for they overestimate the extent of the refutation. The fact that all arguments offered in favor of a proposition have been refuted does not necessarily prove that the proposition is false. It may be that the proposition could be supported by arguments not yet advanced.129 These ideas regarding the overestimation of refutation parallel those of Whately. 130

Finally, Broadus addressed the placement of refutation of objections. Following Ripley's Sacred Rhetoric, he first asserted that a point should be made and objections to it disposed of before the preacher advances his next point.131 If objections lie against the general sentiment of the discourse, and if they can be addressed briefly and independently, they should be refuted before proposing the argument. If refutation depends upon the prior advancement of argument, then it must be postponed until the conclusion. If one chooses

\footnotetext{
128 Ibid.; cf. Whately, pp. $162,165$.

${ }^{129}$ Ibid., p. 214 .

130 Whately, pp. 155-159.

$131_{\text {Broadus, p. } 219 .}$
} 
to delay refutation, knowing that objections are in the hearers' minds, he is advised to intimate at the outset that he will notice objections before concluding. 132

Regarding principles of refutation, there is evidence of Whately's influence, as described above. It is also evident that Broadus borrowed ideas from other theorists as well. In some cases, the sources of ideas are difficult to identify, probably because the notions are so common that they are now considered to be selfevident.

\section{Summary}

The purpose of this chapter has been to explore the personal background of John Albert Broadus, and to explain his theory of argument. Of particular interest was the influence of Richard Whately's theory. Although the influence of other classical and more recent theorists is evident, Broadus's confession that whately's work was freely employed is confirmed in the analysis.

Matters in which Broadus differed from Whately have been included in this chapter, upon the assumption that not only similarities, but also differences should be noted. Broadus followed whately closely in the matters

132 Ibid. Concerning the choice of delay, the influence of Whately is apparent, although the idea itself is Aristotelian. Compare the Archbishop's statement in this regard on p. 147 of his Elements. 
of argument from testimony, analogy, and progressive approach. He also clearly adopted the Englishman's ideas regarding refutation. In the very important matters of presumption and burden of proof, however, Broadus pointedly disagreed with whately.

The analysis of Broadus's addresses and written discourses in the following chapter will undoubtedly disclose the influence of the Archbishop. It will also reveal the differences between the two theorists. 


\section{A RHETORICAL ANALYSIS OF SELECT DISCOURSES OF JOHN A. BROADUS}

In the two preceding chapters the writer has described the theories of argument of Richard whately and John A. Broadus. It has been demonstrated that the former individual exerted considerable influence upon the latter, although Broadus also incorporated ideas from other writers into his Treatise.

The purpose of this chapter is to investigate how and to what extent Broadus applied Whately's theories in three of his own addresses and written discourses. The addresses and discourses will be examined to discover both the application of whately's ideas and the deviations from his theory.

Before proceeding with analysis, a model for critical discourse will be presented. That model will serve as a methodological basis for the rhetorical analysis to follow. 


\section{A Model for Critical Discourse}

In an essay entitled "The Anatomy of Critical Discourse,"l Lawrence Rosenfield proposed a model for the practice of rhetorical criticism. Rosenfield contended that criticism is most sensibly conceived of as a special form of reason-giving discourse. ${ }^{2}$ More specifically, a critic makes evaluative assertions about the way things are and offers reasons to justify his assessments. ${ }^{3}$ This approach is likened unto a forensic argument, in which a claim is based upon an interpretation of a set of facts in light of a legal code. Applied to rhetoric, this means that the facts of a specific rhetorical event are interpreted, and the interpretation is compared to a norm. Judgments are based upon the degree to which the event conforms to or deviates from the norm. 4

If one would engage in rhetorical criticism, he must decide what the relevant data will be. Rosenfield suggested four variables which may be considered in this regard. They are the source or creator of the message

$1_{\text {Lawrence Rosenfield, "The Anatomy of Critical }}$ Discourse," in Methods of Rhetorical Criticism: A Twentieth Century Perspective, second ed., revised, eds. Bernard L. Brock and Robert L. Scott (Detroit: Wayne State University Press, 1980), pp. 148-174.

2 Ibid., p. 148 .

${ }^{3}$ Ibid., pp. 153,154 .

${ }^{4}$ Ibid., pp. $155,156$. 
(S), the message (M), the environment, including matters of historical background and context in which the message is received (E), and the critic, who is a unique receiver (C) .5 A total interpretation of a communicative event would require analysis of all four variables. Such analysis is, however, rare if not impossible for one critic. 6 Therefore, various combinations of these variables may be considered. For the rhetorical critic, the indispensible variable is the message (M). 7

After determining what will constitute relevant data, the critic must formulate a basis or standard for comparison. Rosenfield suggested two types. One he called "analog modality," in which an actual speech or address is selected to serve as a standard of comparison for another. The other type he called "model modality," in which the critic generates his own paradigm of an ideal to serve as a standard of comparison. 8 The search for an explanation for the extent and character of deviation from the model constitutes the invention of critical reasons. ${ }^{9}$ In the model modality, the critic's norm is generated from

${ }^{5}$ Ibid., p. 159.

6 Ibid.

7 Ibid.

${ }^{8}$ Ibid., pp. $170,171$.

${ }^{9}$ Ibid., p. 171 . 
a theoretical base. The comparison of a discourse to the model serves to confirm or to qualify the theory represented by the model. Comparison also is used to assess the discourse. 10

This writer will use Rosenfield's approach to analyze and assess three of Broadus's discourses. Of the four variables which Rosenfield suggested, the source (S) and the message (M) will provide the relevant data. Rosenfield's description of the interaction of these two variables follows:

The S-M focus concentrates on understanding discourse as an expression of its creator. Most often the critic attempts to trace out the creative process by which the speaker externalized and structured the feelings, thoughts, and experiences contained within himself. The relation of source to message has prompted two general schools of criticism. One (which actually concentrates on the $S$--> M relationship) seeks to account for the rhetor's behavior as a function of the factors which influenced him: his education, the books he read, the persons who inspired him, and the like.1l

These two variables were chosen because they naturally and adequately accomplish the stated purpose of this study. The notions of argument stated in previous chapters constitute the influences, particularly that of whately, which determined the viewpoint of a rhetor, Broadus. It can be expected that his messages will reflect those

$$
\begin{aligned}
& { }^{10} 0_{\text {Ibid. }}, \text { p. } 172 . \\
& { }^{11_{\text {Ibid. }}}, \text { p. } 161 .
\end{aligned}
$$


influences. Analysis will disclose the form and substance of Broadus's approach to the argumentive materials in the discourses.

Following Rosenfield's "model modality," the standard of assessment will be a paradigm based upon Whately's theory of argument. It is expected that both conformity and intentional deviation will be discovered, since in his Treatise, Broadus stated that he employed whately's notions, but with additions and corrections. 12

\section{A Paradigm Based Upon Whately's Theory}

Whately's theory was discussed in chapter two, and therefore will not be reviewed here in detail. Selected portions of that theory will be included in a paradigm to be used in analyzing and assessing Broadus's discourses. The criteria for choosing the selected portions are named and developed below.

\section{Criteria for the Paradigm}

First, it must be remembered that whately's theory en toto was not incorporated into Broadus's Treatise. In other words, some ideas of Whately's were omitted. The reasons for omissions are not known, but possibilities

12 John A. Broadus, Treatise on the Preparation and Delivery of Sermons (New York: Hodder and Stoughton, 1898), p. xi. 
might be suggested. It is possible, for instance, that Broadus expected his readers to examine whately's work for themselves, making duplication in his Treatise unnecessary. This possibility is strengthened by the fact that in his section on relevant literature he urged the reading of several authors, including whately. Another possible reason is that to include most or all of Whatley's ideas would make the Treatise too long. The fact that Broadus treated several notions only briefly could indicate that he recognized the need to limit the scope of his work. It is also possible that he chose those ideas which he considered most important. This final possibility seems most likely, and does not exclude the other two as concurrent explanations. In any case, the criterion which will be inferred from the above is that only those elements of Whately's theory which appear in Broadus's Treatise will be included in the paradigm.

second, it must be remembered that not all of Whately's ideas were original. He borrowed many of his ideas from the classic rhetoricians. That which gave the ideas he borrowed distinction was his extensive development and modification of some, and the ecclesiastical application he made of most, if not all. The second criterion, then, which an element must meet to be included is that it must be, in the opinion of experts, among Whately's original or otherwise significant contributions. 
Third, in the very important matters of presumption and burden of proof, for example, Whately and Broadus did not agree. Broadus's discussion of the disagreement was developed in chapter three, in which the differences between the two men were carefully noted. As a criterion concerning matters in which the two disagreed, Whately's notions are included in the paradigm. Deviation from the standard can be expected in the discourses, however, insofar as such ideas are concerned.

Fourth, Broadus adopted ideas from other sources. Such ideas will not be included since the fourth criterion is that only whately's ideas will constitute the paradigm. It is likely that ideas from other theorists are reflected in the addresses. These ideas may be noted in passing, but they will not receive primary analysis or emphasis.

\section{Elements of the Paradigm}

Based upon the criteria stated above, the elements included in this paradigm must appear in whately's Rhetoric, they must also appear in Broadus's Treatise (either confirmed or disputed), and they must be judged by experts to be original and/or significant contributions made by the Archbishop in the field of rhetoric. Based upon the discussion and analysis of chapters two and three, the following elements meet the criteria: presumption, burden of proof, argument from testimony, argument 
from analogy, and refutation. According to nature and function, these elements can be placed in three groupings: 1) presumption and burden of proof, 2) forms of argument (including those from testimony and analogy), and 3 ) refutation.

It is significant that the list of elements Broadus included in his treatise and those which are considered by expert opinion as Whately's contribution to the field of rhetoric are almost identical. Broadus's list was longer, adding some of Whately's principles governing order of arguments and also including two varieties of argument, a priori and argument from induction. otherwise, the two are remarkably alike.

Because Whately's ideas were discussed in chapter two, they will not be repeated here. They will be briefly reviewed below, however, when appropriate and helpful in the discussion of Broadus's discourses.

Before proceeding with the analysis, it should be observed that this paradigm does not provide an exhaustive model for studying argument. Many forms of argument and principles of argumentation are not included, even though they appear both in Whately's Rhetoric and in Broadus's Treatise. The paradigm has been designed to allow an examination and assessment of Whately's most significant contributions, as recognized and applied by Broadus. 
It must be further observed that Broadus did not employ every element of the paradigm in every discourse studied. Presumption and burden of proof will be examined in each case, but the nature of the subject matter and the situation involved will bear heavily upon the varieties of argument employed and the amount and form of refutation required. Explanations will be suggested to account for omissions, but the mere fact of such omissions must not be construed as a weakness in Broadus's addresses.

\section{An Analysis and Assessment of Three Discourses of John Broadus}

The three discourses to be analyzed and assessed are "Duty of Baptists to Teach Their Distinctive Views," "Should Women Speak in the Public Assemblies?" and "Immersion Essential to Christian Baptism." The addresses will be examined in the order listed above, which corresponds to their chronological sequence.

"Duties of Baptists to Teach

Their Distinctive Beliefs"

Background of the Address

This particular address was delivered in 1881 at the fifty-seventh annual meeting of the American Baptist Pub- 
lication society.13 It is evident, therefore, that the audience to which this address was originally given was primarily, if not exclusively, Baptist.

In addition to the external evidence cited above, this conclusion is supported by internal evidence. For example, Broadus introduced his proposition using a first person, plural pronoun to refer to himself and to his audience. He said, "Hence, the text lays upon us the duty of which I have been requested to speak--the duty of Baptists to teach their distinctive views." 14 First person, plural pronouns were also regularly employed in the reasons offered in support of the proposition. The following sentences are a few of many which identify the Baptist character of the audience through the use of the first person.

1. It is a duty we owe ourselves. We must teach these views in order to be cons istent in holding them. Because of these we stand apart from other Christians, in separate organizations-from Christians whom we warmly love and delight to work with. We have no right thus to stand apart unless the matters of difference have real importance; and if they are really important, we certainly ought to teach them. 15

${ }^{13}$ Edward C. Starr, ed., A Baptist Bibliography, 25 vols. (Chester: American Baptist Historical Society, 1953) 3:150.

$14 \mathrm{John}$ A. Broadus, "The Duty of Baptists to Teach Their Distinctive Views" (Philadelphia: American Baptist Publication Society, n.d.), p. 6.

${ }^{15}$ Ibid., pp. 11,12 . 
It is also significant that Broadus had been assigned the topic for this address, as indicated in his statement of the proposition, quoted above. Not only was he speaking to an audience likely to be sympathetic with his views; he was also addressing a topic concerning which they desired to hear his opinions.

\section{An Overview of the Address}

The Biblical text for this address was Matthew 28:20, in which Jesus charged his disciples, saying, "Teaching them to observe all things whatsoever I have commanded you." Broadus began his address with a brief exposition of his text, from which he inferred that "all things" included not only matters of personal piety, but also rules governing Christian societies, or churches. From the exposition of his text, he inferred his proposition, which was this: "Hence, the text lays upon us the duty of which I have been requested to speak--the duty of Baptists to teach their distinctive views." 16

Following the statement of the proposition, Broadus listed and described briefly the distinctive views of which he spoke. He named four: 1) that the Bible alone is a religious authority; 2) that a Christian Church ought to consist only of persons who make a credible profession of conversion; 3) that officers, government, 
and ceremonies of a church ought to be such, and only such, as the New Testament directs; and 4) that churches ought to be independent, free from the control of other churches and separate from the state. 17

His first distinctive view he simply stated. The second he elaborated, arguing that this one precluded infants from church membership and implying that one whose life did not provide credible evidence of conversion should not be retained in membership. ${ }^{18}$ The third notion he developed relatively extensively, referring to the significance of the ceremonial ordinances of baptism and communion. He amplified the fourth distinctive, stating that independence does not preclude cooperation with other churches and that separation of church and state does not allow the church to violate moralities essential to public welfare. 19

After stating those principles which he believed to be the distinctive views of Baptists, he offered four reasons for teaching them. First, he said, it is a duty to ourselves, because teaching these views justifies separation from other religious groups and also corrects the excesses of some who claim to be Baptists. Second, he

$$
\begin{aligned}
& { }^{17} \text { Ibid. } \\
& { }^{18} \text { Ibid. pp. } 6-10 . \\
& { }^{19} \text { Ibid. }, 6,7 .
\end{aligned}
$$


said, it is a duty to fellow Christians who need to understand Baptist views. Third, it is a duty to the unbelieving world in that through asserting these views the assaults of infidels might be met. Fourth, it is a duty owed to Christ, who charged his disciples to teach all things that he had commanded them. 20

The final section of the address was devoted to six suggested means and methods for performing the duty urged by the proposition. Those six included 1) thorough instruction of Baptists themselves, 2) improvement of the character and influence of the churches, 3) understanding the audience to be taught, 4) skillful treatment of controverted topics, 5) cooperation with other denominations without sacrificing convictions, and 6) cultivation of unity among Baptists. 21

An Analysis and Assessment of the Arguments

Having surveyed the contents of Broadus's address, the writer will now analyze and assess those contents according to the paradigm described above. All elements of the paradigm may not appear in this address, but an at tempt will be made to deal with those which do occur.

$$
\begin{aligned}
& { }^{20}{ }_{\text {Ibid. }}, \text { pp. } 11-20 . \\
& 21_{\text {Ibid. }}, \text { pp. } 20-35 .
\end{aligned}
$$


Presumption and Burden of Proof

The first elements of Whately's paradigm which serve as a standard of analysis and assessment are the notions of presumption and burden of proof. As noted elsewhere, Whately identified presumption with preoccupation of ground. The burden of proof rests upon the one who challenges presumption.

Whately noted that presumption can vary from situation to situation, depending upon the biases of the audience. This fact is significant in analyzing this address. It is evident from the use of first person, plural pronouns that Broadus was addressing a Baptist gathering. Although all present may not have been predisposed to the propagation of Baptist views, as called for by the proposition, most could reasonably be expected to accept the distinctive views Broadus listed and described. At least to a certain extent, then, he could claim presumption in his favor upon the occasion of this address.

A second aspect of Whately's description of presumption is important in this address. The Archbishop spoke of authority as a matter of "habitual presumption." Such presumption may favor the decisions or opinions of "an individual, a body, or a book."22 Broadus's views

${ }^{22}$ Richard Whately, Elements of Rhetoric, ed. Douglas Ehninger (Carbondale: University of Southern Illinois Press, 1963), p. 118. Emphasis mine. 
regarding the authority of the Bible, expressed not only in his Treatise, but also as the first distinctive view of Baptists stated above, indicate that for himself and for other Baptists any proposition taught by the Bible has presumption in its favor.

It appears that Broadus recognized presumption to be in his favor, for the address consists primarily of appeals and assertions rather than extensive arguments. Knowing that his audience was a Baptist audience, he did little to defend the distinctive views he asserted, although he undoubtedly knew that individuals of other theological persuasions would dispute his convictions. It is also evident from his introductory exposition of his text, Matthew 28:20, and the implied reference to it in his fourth reason, that Broadus understood the New Testament to support his proposition. For him and his audience the weight of habitual presumption conclusively favored his assertion.

Because in this situation, presumption favored Broadus, Whately would argue that the burden of proof rested upon those who would dispute the proposition. Broadus would be required only to refute the objections to the proposition in order that it might stand. According to his own theory, however, Broadus would place the burden of proof upon himself despite the benefit of presumption, 
for he stated that he who alleges bears the burden of proof.

A review of the address indicates that Broadus followed his own viewpoint rather than that of whately, in that he offered four reasons in support of the proposition. However, it should be noted that his reasons were not strongly argumentative in nature. He addressed a few objections raised against them, as will be demonstrated below, but his primary development of reasons consisted of little argument. For example, as a portion of the development of his first reason, i. e., that the teaching of distinctive views is a duty owed to ourselves, he gave an explanation, as he wrote:

And this teaching is the only way of correcting excesses among ourselves. Do some of our Baptist brethren seem to you ultra in their denominationalism, violent, bitter? And do you expect to correct such a tendency by going to the opposite extreme? You are so pained, shocked, disgusted, at what you consider an unlovely treatment of controverted matters that you shrink from treating them at all. Well, the persons you have in view, if there be such persons, would defend and fortify themselves by pointing at you. They would say, "I am complained of as extreme and bigoted. Look at those people yonder, who scarcely ever make the slightest allusion to characteristic Baptist principles, who are weak-kneed, afraid of offending Paedobaptists, or dreadfully anxious to court their favor by smooth silence: do you want me to be such a Baptist as that?" Thus one extreme fosters another.23

23 Broadus, "Duty. . . ," pp. 12, 13. 
Forms of Argument

At this point the writer will analyze forms of argument in Broadus's address. The paradigm allows the study of arguments from testimony and from analogy. To analyze only for these three forms is not to suggest that other forms of argument are not used in the address, nor is it to suggest that all three forms necessarily should be employed. Indeed, other forms of argument appear, and only one of these two appears in this address.

An argument from analogy, as previously defined, is one in which an instance adduced is somewhat remote from that to which it is applied. The resemblance between the two instances is one of ratios. The likeness is not one of essence, but is rather a likeness of relationship. Errors arise if one assumes that likeness of relationship implies likeness of essence or if one presses the comparison further than it was intended to be pressed. The genius of understanding this variety of argument is in determining which points of comparison make the argument. Twice in this discourse Broadus employed the argument from analogy. In both instances he used the same analogy to make essentially the same point, although the second instance is slightly different from the first and is used to support a separate proposition. 
Broadus first used this argument in the development of his third distinctive view, which stated, in part, that the only ceremonies of a church should be those which the New Testament requires. He named two such ceremonies, baptism and communion. The argument from analogy was used to support his contention that to be baptized is tantamount to taking an oath of allegiance to Jesus Christ. He noted that the early Roman Christians had called baptism a sacramentum, which in common Latin usage was used of a military oath. From this common use he framed his analogy, as follows:

The early Roman Christians had a good word for this idea if only the word could have remained unchanged in use: they called it a sacramentum, a military oath. As the Roman soldier in his oath bound himself to obey his general absolutely so in baptism we solemnly vow devotion and obedience. ${ }^{24}$

The point of analogy is clearly in a relationship. The comparison is not between a Christian and a soldier, nor is it between christ and a general. The analogy is that as a soldier with a sacramentum vows absolute obedience to his superior officer, the Christian by the "sacrament" of baptism vows devotion and obedience to

$$
24 \text { Ibid., p. } 8 .
$$


Christ. 25 The analogy is in the relationship between two individuals as mediated by an oath.

The second use of this form of argument is in the support of Broadus's fourth reason that Baptists should teach their distinctive views, namely, that it is a duty to Christ. The professor again used the analogy of the Roman soldier under oath, but with an imaginative twist:

-. what shall hinder us, what could excuse us, from observing them ourselves and teaching them to others? The Roman soldier who had taken the sacramentum did not then go to picking and choosing among the orders of his general: shall the baptized believer pick and choose which commands of Christ he will obey and which neglect and which alter? 26

The point argued in this analogy is that the Baptist 1 istener was not at 1 iberty to excuse himself from the duty imposed by the proposition of the discourse. As in the previous use of this argument, the comparison is in the relationship of an individual to another to whom he had vowed allegiance. In the first occurrence, the emphasis was upon that which the oath affirmed, namely

obedience. In the second the emphasis is upon that which the oath precludes, namely selective obedience. Both, however, argue from the ratio or relationship of ideas

25 Because the Roman Catholic use of the term "sacrament" denotes a means of mediating divine grace, Baptists, including Broadus use instead the word "ordinance" to refer to baptism.

$$
26 \text { Broadus, "Duty. . .," pp.19, } 20 .
$$


rather than from a comparison of the essence of the individuals involved.

In this discourse, then, Broadus employed to a limited extent the argument forms for which whately is best known. Although the argument was limited in its extent, it was sufficient for the occasion upon which the address was delivered. With an audience primarily in agreement with his propositions, it was not as necessary to establish a proposition through argument as it would have been with one unconvinced. His conformity to the paradigm should not be judged by the number of arguments he employed from it, nor should he be expected to use all three forms in the address. Rather, he should be judged according to the degree to which he conformed to whately's notions when, in the address, the argument form would be useful .

The fact that only two instances of argument are cited above does not imply that other varieties of argument were not employed. There are several instances of induction, for example. The primary burden of the address was to urge a course of action which was probably acknowledged by his audience to be at least mildly desirable. Therefore, he offered reasons to justify his proposition but did not need elaborate argument to establish it. 
Refutation

Whately believed that refutation is a specialized use of regular forms of argument. Therefore, most of his notions regarding the subject relate to arrangement and other considerations which make refutation most effective, rather than to forms. In the following analysis, particular principles will be noted as applicable to Broadus's discourse.

Because he was addressing an audience which could be expected to be mostly in sympathy with his views, Broadus treated few objections. Had he been presenting the same material to a broader religious audience, it would have been necessary not only to support the distinctive views he asserted with affirmative argument, but also to refute the objections that individuals of other theological viewpoints would raise.

Although he presented little argument in the development of his distinctives, it is in regard to the second of these that the first instance of refutation occurs. Whately had urged that refutation be placed in the midst of argument, and this Broadus did. Immediately after asserting his position, he raised the opposing viewpoint and then attempted to refute the opponent.

Having asserted that Baptists require a credible profession of conversion as a condition of church membership, he noted that such a statement precludes infants 
from membership. Recognizing that such a conviction is contrary to the view of many protestants, Broadus chose to address the opposing viewpoint. He said:

The notion that infants may be church-members because their parents are seems to us utterly alien to the genius of Christianity, not only unsupported by the New Testament, but in conflict with its essential principles; and we are not surprised to observe that our christian brethren among whom that theory obtains are unable to carry it out consistently--unable to decide in what sense the so-called "children of the church" are really members of the church and subject to its discipline. The other notion, that infants may be church-members because so-called "sponsors" make professions and promises for them, seems to us a mere legal fiction, devised to give some basis for a practice which rose on quite other grounds. 27

The preceding subjoins three refutational statements to the implied proposition that infants could be members of churches because their parents are. First, he said, the practice is unsupported by the New Testament and, in fact, conflicts with its teaching. Second, the practice cannot be carried out consistently. Third, the notion of sponsorship is groundless.

The order of these is significant, in that Broadus began with his strongest argument. Given his views of the authority of the Bible, the conflict of infant membership with Bible teaching was, for him, a sufficient refutation of the proposition. To strengthen the case, however, he offered the other two arguments, an act consistent with 
his own belief that sometimes individuals will give greater consideration to arguments from sources other than the Bible.

The brevity of these arguments lessens their effect. His first argument could have been strengthened by treatment of the specific theological arguments offered by the opponents. His second one would have been helped by explanation. The third one is difficult to understand, and appears to be an arbitrary dismissal of the opponent's practice. The generalized way in which these refutations addressed the issue may have been sufficient for an audience already convinced of Broadus's proposition (i.e., that the need for credible profession of conversion as a condition for church membership precludes infants). However, it is unlikely that a pedobaptist would be persuaded to change his belief based upon this refutation.

A second instance of refutation is addressed to an implied objection Broadus raised after he stated the distinctive views of Baptists as he understood them. Following are his remarks from which the implication is inferred.

Now, I repeat that we do not consider these externals to be intrinsically so important as the spiritual, or even the ethical, elements of Christianity. But they are important, because they express the spiritual and react upon it healthily or hurtfully, and because the Author of Christianity, in person or through his inspired apostles, appointed and commanded them. And we think it a matter of great importance that they 
should be practised in accordance with, and not contrary to, his appointment--that, in the language of his text, his disciples should observe and conserve (for the word includes both ideas)

all things whatsoever he commanded them. 28

The implied objection is that Baptist distinctive views are really inconsequential, particularly when compared with the spiritual or ethical elements of Christianity. Broadus conceded that the spiritual and ethical are of greater importance. However, he countered that the externals are important, because they cannot be separated from the spiritual and because Jesus commanded that they be taught. The refutation in this case consists of argument to establish a counter proposition which, as Whately said, in effect refutes its contrary. Again, one of his primary appeals was to the authority of the Bible, as specifically expressed in his chosen text.

Conjoined with his second reason that Baptists should teach their distinctive views, namely, that it is a duty owed to fellow Christians, is a third instance of refutation. Applying Whately's dictum that objections should be handled nearer the beginning than the end, Broadus immediately raised the common objection that denominational differences should be minimized in the greater interest of Protestantism. He stated the objection and his refutation as follows:

${ }^{28}$ Ibid., pp. 10,11 . 
We are often told very earnestly that Baptists must make common cause with other Protestants against the aggressions of Romanism. It is urged, especially in some localities, that we ought to push all our denominational differences into the background and stand shoulder to shoulder against Popery. Very well; but all the time it seems to us that the best way to meet and withstand Romanism is to take Baptist ground; and if, in making common cause against it, we abandon or slight our Baptist principles, have a care lest we do harm in both directions. Besides, ours is the best position, we think, for winning Romanists to evangelical truth. . . If well-meaning Roman Catholics become dissatisfied with resting everything on the authority of the church and begin to look toward the Bible as authority, they are not likely, if thoughtful and earnest, to stop at any halfway-house, but to go forward to the position of those who really build on the Bible alone. 29

Whately urged that one state an opponent's objections with full force, lest he appear to evade the issue. Broadus in this instance gave a stronger statement of the contrary viewpoint than he had in previous cases, in which the objections were implied rather than explicitly stated. In this matter, then, the Professor conformed to the Archbishop's theory.

The refutation offered was a conjectural counter proposition, namely, that the better way to withstand the encroachments of Roman Catholicism was to stand firmly for Baptist convictions. In form, this approach comports nicely with whately's theory, but the substance of the argument in this case is not compelling. The basis of his proposition was that "it seems to us" to be the better 
alternative. 30 Perhaps his testimony carried great weight with that audience, but several examples of success based upon his proposed approach would have been more convincing. He explained his proposal with a hypothetical case, which could very easily be challenged.

A fourth instance of refutation was also a part of the development of the second reason for teaching Baptist distinctives. In this case, Broadus had suggested that such teaching was a duty owed to other christians so that they might consider Baptist views and adopt them if they were found convincing. Again with full force, he stated the objection that other Christians need not be proselytized as follows:

But why should we wish to make Baptists of our Protestant brethren? Are not many of them noble Christians--not a few of them among the excellent of the earth? If with their opinions they are so devout and useful, why wish them to adopt other opinions? ${ }^{31}$

Whately, with his penchant for satire, had suggested that an indirect means of refutation is to prove an absurdity using the opponent's own premises as the basis of reasoning. 32 It was this element of whately's theory that

$30_{\text {Ibid.., p. } 13 .}$

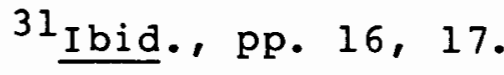

32 This notion comports well with the reductio ad absurdum form of argument. 
Broadus applied to refute the objection at hand. He wrote:

Yes, there are among them many who command our high admiration for their beautiful christian character and 1 ife; but have a care about your inferences from this fact. The same is true even of many Roman Catholics, in the past and in the present; yet who doubts that the Romanist system as a whole is unfavorable to the production of the best types of piety? ${ }^{3} 3$

The point of the argument is that desirable Christian character is not the measure of a system of doctrinal belief. If it were, Roman Catholic doctrine would have to be deemed acceptable based upon the noble character of many Catholics. His audience, of course, would not concede that Roman Catholic doctrine could be accepted and therefore could not assert that noble character can be the measure of belief.

\section{Summary}

Although in his own Treatise Broadus discounted the importance of presumption and burden of proof, he relied heavily upon presumption in his favor, as whately defined the notion. His approach to his subject assumed that his audience was predisposed to agree with his assertions. He also, as expected, employed Whately's notion of "habitual presumption" concerning the Bible. This is evident in the number of times that he used his text from

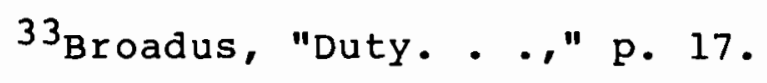


Matthew 28:20 to support his major proposition, that Baptists are duty-bound to teach their distinctive views. Following his own dictum that if possible, the strongest argument should be presented last, his fourth argument was that this teaching was a duty owed to Christ, in keeping with his command recorded in the Bible. He would consider this to be his strongest argument based upon his view of the supreme and final authority of the Bible.

Regarding the matter of burden of proof according to Whately, Broadus would have been required only to answer objections against his proposition. He did more than answer objections, however. Consistent with his own view that he who alleges must prove, he deviated from the paradigm and assumed the burden of proving his proposition that Baptists are duty-bound to teach their distinctive views.

It was noted above that this discourse involves surprisingly little argument. Rather, it consists largely of affirmations, explanations, illustrations, suggested ways and means, and appeals. This fact was probably due to the predisposition of the audience in favor of Broadus's ideas. Because the paradigm permits the study of only three argument forms, only two cases of argument from analogy were examined. In both cases, Broadus correctly applied whately's ideas. 
Several instances of refutation were discovered in the discourse, and these regularly conformed to various principles which whately had articulated for governing the process. The substance of the refutative arguments was not convincing in every case, but in form, they followed the paradigm.

"Should Women Speak in Mixed

Public Assemblies?"

\section{Background of the Discourse}

The subject of the second discourse to be studied is evident from its title. Historically, it was presented at a time when women's issues such as suffrage were prominent in society. It was probably inevitable that the question of the role of women in the churches would arise.

Whereas the previous discourse was oral, this one was written. It was published in booklet form in 1890 by Baptist Book Concern. 34 It was disseminated among Baptists, including Dr. W. C. Wilkinson, who in a letter to Dr. Broadus, wrote:

Thank you heartily for your leaflet, "Should women Speak in Mixed Assemblies?" I had been wishing I could see it and wondering just how to get it. It shows you the same consummate master of persuasive presentation that I have always felt you to be. ${ }^{35}$

${ }^{34}$ Starr, 3:153.

${ }^{35}$ A. T. Robertson, Life and Letters of John Albert Broadus (Philadelphia: American Baptist Publication Society, 1901), p. 390. 
Wilkinson's statement includes at least one promient individual's opinion of the merits of the discourse as well.

Internal evidence indicates that this discourse was addressed to a Baptist audience. Broadus pointed out, for example, that one specific objection he addressed had been raised by a Baptist lady. Toward the end of the document, he traced the origin of the practice in question among non-Baptist denominations. He then contrasted the doctrinal assumptions of these groups with Baptists, arguing that Baptist doctrines would support his view. In his final remarks, he made an appeal through a rhetorical question which clearly identified his audience:

Is it too much to hope that our excellent Baptist ladies who have fallen in with the movement in some parts of the country will stop while they can, will exclude men from their women's meetings, will decline to join in temperance addresses to assemblies composed of both men and women? ${ }^{36}$

Internal evidence also indicates that Broadus was aware that all members of $\mathrm{h}$ is intended audience did not agree with his proposition. In addition to the Baptist lady who raised an objection, referred to above, Broadus acknowledged the contrary opinion of other Baptists. He referred to one such individual as follows:

$36_{\mathrm{J} o h n}$ A. Broadus, "Should Women Speak in Mixed Public Assemblies?" (Louisville: Baptist Book Concern, $1890)$, p. 16. 
A justly honored Baptist pastor was not long ago reported as saying (in substance) that he did not want to hear so much about texts on this subject; the thing does good, and that was enough for him. 37

At the same time, he asserted that the great majority of Baptist women were distinctly opposed to the practice in question. 38

An Overview of the Discourse

This discourse began with a direct reference to a controversial issue: the appropriateness of women speaking in mixed public assemblies. After commenting briefly upon the contemporary issue, Broadus defined the limits he intended to place upon his subject. First, he would confine his treatment to the issue raised in the title rather than discussing the broader issue of women's rights. Second, he would be primarily occupied with an attempt to explain the passages of Scripture which appear to forbid women to speak in mixed public assemblies. 39 His explanation included arguments involving the interpretive judgments he made.

Following these introductory comments, Broadus cited two Biblical texts as translated in the Revised English Version. He quoted I Corinthians 14:34f, which reads:

$$
\begin{aligned}
& 37 \text { Ibid., p. } 14 . \\
& { }^{38}{ }_{\text {Ibid }}, \text { p. } 15 . \\
& { }^{39_{\text {Ibid. }}} \text { p. } 2 .
\end{aligned}
$$


Let the women keep silence in the churches; for it is not permitted unto them to speak; but let them be in subjection, as also saith the law. And if they would learn anything, let them ask their own husbands at home; for it is shameful for a woman to speak in the church. 40

He then referred to I Timothy 2:11-15, broadly paraphrasing and commenting upon the preceding context, which addresses the subject of order in public worship. The verses which pertained to his discourse read as follows:

Let a woman learn in quietness with all subjection. But I permit not a woman to teach, nor to have dominion over a man, but to be in quietness. For Adam was first formed, then Eve; and Adam was not beguiled, but the woman being beguiled, hath fallen into transgression; but she shall be saved through the child-bearing, if they continue in faith and love and sanctification with sobriety. 41

Following a few comments regarding the suitability of the translation from which he quoted, Broadus set forth his proposition that the texts in question forbid women to speak in mixed public assemblies. He stated his position as follows:

Now it does not need to be urged that these two passages from the Apostle Paul do definitely and strongly forbid that women shall speak in mixed public assemblies. No one can afford to question that such is the most obvious meaning of the apostle's commands. 4

Subjoined to the proposition is a series of six objections, each of which Broadus refuted in turn. The

40 I Cor. $14: 34,35$ (RV).

${ }^{41} 1_{\text {I }}$ Tim. 2:11-15 (RV).

42 Broadus, "Should Women Speak. . . " p. 4. 
objections were: 1) that "speak" in I Corinthians 14:34 means "chatter;" 2) that "church" in the same verse refers to the formal public meeting; 3) that prophetesses mentioned I Corinthians $11: 5$ spoke in mixed public assemblies; 4) that the prohibition was culturally conditioned, and not applicable beyond the immediate audience; 5) that Broadus's proposition would permit women without husbands to speak; and 6) that the documents of these texts were corrupt.

To conclude, he summarized his understanding of the texts, satisfied that he had adequately refuted the objections. He also suggested what he considered to be implications and applications of the proposition that he had maintained.

The leaflet which the author examined includes an addendum written after the address had been published. In this addendum, Broadus answered three more objections which apparently he had not foreseen. Those are: 1) that the Apostle Paul was biased and contradicted the teaching of Jesus; 2) that women had been speaking in mixed assemblies with good results; and 3) that Baptists would lose the beneficial effects of a growing movement by forbidding the practice.

The conclusion of the addendum involves an appeal to adopt the proposition in practice. Claiming that the majority of Baptist women concurred with his viewpoint, he 
called upon those who did not to consider and apply his message.

\section{An Analysis and Assessment of the Discourse}

Again the three categories of the whately paradigm will be applied as the standard of analysis and assessment. The pattern of discussion, however, will differ somewhat from that of the first address. First presumption and burden of proof will be examined. Then each issue named in the overview above will be analyzed. Elements of refutation will receive primary attention, because each issue was presented as an objection to his major proposition. Forms of argument, as outlined in the paradigm, will be discussed as they arise.

Presumption and Burden of Proof

Whately's notions concerning presumption and burden of proof have been stated elsewhere, so a complete statement of his ideas is not necessary at this point. However, a review of those conceptions pertinent to the address at hand may be helpful. First, presumption is the preoccupation of ground rather than preponderance of probability in favor of a particular proposition. Second, presumption stands against the paradoxical, or that which is contrary to prevailing opinion. Therefore, the biases of an audience may determine upon which side of a question 
presumption falls. Third, habitual presumption, or authority, may favor the decisions or opinions of an individual, a body, or a book. Fourth, the burden of proof rests upon the one who disputes the position favored by presumption. Fifth, if presumption favors one's proposition, he needs only to answer objections in order to sustain his proposition.

In this address, Broadus assumed that presumption favored his view. This is evident in two ways. First, he supposed that the majority of prevailing opinion among Baptists was opposed to the practice in question. This belief he stated as follows:

It is a comfort to know that the great majority of Baptist women in our country as a whole are still distinctly opposed to this practice. Such is the case almost universally in New England (if I am correctly informed), quite generally in the Middle States, and with very few exceptions throughout the South and Southwest. 43

Because the audience he hoped to persuade was a Baptist audience, and the prevailing opinion and audience bias were in his favor, he could enjoy the "comfort" of presumption, as indicated in his statement above.

The second element which placed presumption in his favor was the habitual presumption among Baptists that the judgments of the Bible are authoritative. That he employed this notion is evident in several ways. First,

43 Ibid. , pp. 15, 16. 
after introducing the question, he suggested to his audience an appropriate answer must be consistent with the Bible. He wrote:

No thoughtful person would like to profess that in our country at the present moment he can make this investigation in a completely impartial and dispassionate manner; but it is obviously very desirable that writer and readers in such a case should earnestly strive to deal fairly with their own minds and with the truth of God.

Second, immediately following this statement he quoted the two Biblical passages from which he inferred his proposition. Third, the concluding statement of the discourse proper cites Biblical authority as the conclusive reason establishing the assertion. Following is that conclusion:

As to crying out against the Bible for teaching "the subjection of women," leave that to Ingersoll. The precise nature and proper limits of this subjection may not be generally understood, and would be an appropriate subject for earnest inquiry. But that the Bible does teach subjection, and that the apostle makes that his special reason for the prohibition before us, would seem to be quite beyond question. 45

According to Whately, since presumption was in Broadus's favor, the burden of proof rested with one who would challenge his assertion. Broadus, on the other hand, had said that the burden of proof rests with the one who alleges. Broadus may have believed that in this instance he proved his proposition. However, his only

${ }^{44}$ Ibid., p. 2. Emphasis mine.

45 Ibid., p. 10 . 
1 ine of proof was to assert that the obvious sense of the two texts he quoted established his viewpoint.

It is the opinion of this writer that in this discourse Broadus followed Whately's approach to burden of proof rather than his own. If he had seriously assumed the burden of proof, he would have been obligated to prove not that the Bible was to be accepted as authoritative, but that the "obvious" sense of his texts was the actual sense. Furthermore, the argumentative substance of the discourse, following the statement of the proposition, is entirely the refutation of objections. He had, therefore, adopted Whately's dictum: if presumption favors one's proposition, he needs only to refute objections to confirm the assertion. His own statement, following the six refutations in the discourse proper, expressed his belief that he had refuted the objections and thus confirmed the proposition. He observed, "So the apostle's clear and consistent prohibitions stand unshaken, in their obvious sense." 46

Refutation

As stated in the overview above, Broadus refuted nine objections to his proposition. Six of these were in the discourse proper. The remaining three were presented in an addendum written subsequent to publication. 
The first objection Broadus addressed was that the term "speak" in I Corinthians 14:34 means "to chatter."47 The implication of this objection is that the prohibition applied only to disorderly speech, but would not exclude intelligent speaking. Broadus stated the objection with full force, as whately urged, acknowledging that in classical Greek the term was sometimes used not only for chattering, but also to refer to animal sounds.

To refute this argument, Broadus observed that there are no clear examples of these classical uses in Biblical Greek. Instead, he asserted, the New Testament uses the term to refer to intelligent speaking or talking, applying the word to apostles, prophets, the Savior, and God. Implied is the unlikelihood that these would engage in "chatter." This approach conforms to Whately's notion that one may refute an objection by proving its opposite. Whately also said, as noted elsewhere, that refutation involves the specialized use of ordinary argument forms. In this refutation Broadus used an argument from testimony, which is one of the three forms included in the paradigm. The testimony he cited was that of the wellknown and widely-accepted Thayer's Greek-English Lexicon

47 Ibid., p. 5. 
of the New Testament. 48 Whately asserted that in matters of opinion, the strength of the testimony of a witness depends upon expertise or the ability of the witness to form a judgment. In this case, Broadus selected a highly credible witness to support his definition and thus to refute the objection. Thayer was the Bussey Professor of New Testament Criticism and Interpretation at the Harvard Divinity School.49

The second objection Broadus addressed was that the word "church" in I Corinthians 14:34 referred to a formal public meeting rather than informal gatherings. 50 The implication of the objection is that women could speak in smaller, informal gatherings. To refute this argument Broadus challenged the objector's premise, arguing that the distinction between formal and informal gatherings is a modern one which cannot be imposed upon the historical situation here involved. He argued that, in fact, the

48 Joseph H. Thayer, A Greek-English Lexicon of the New Testament, corrected ed. (New York: Harper \& Brothers, Franklin Square, 1889), s.v. laleo. Thayer included five nuances of the term, including 1) to utter a voice, emit a sound, 2) to speak, i.e., to use the tongue or the faculty of speech, to utter articulate sounds, 3) to talk, 4) to utter, tell, and 5) to use words in order to declare one's mind and disclose one's thoughts. Thayer noted that the term is used of animal noises and of human chatting and prattling. I Cor. 14:34, however, is listed as an example of the fifth use, signifying that in Thayer's opinion, the reference is to intelligent speech.

$$
\begin{aligned}
& 49 \text { Ibid., title page. } \\
& { }^{50} \text { Ibid. }
\end{aligned}
$$


kind of abuse addressed by the text was one which could arise only in an informal meeting, because early church gatherings were held in private houses and lacked the formality of contemporary worship services. Therefore, he said, the distinction required by this objection failed. The third objection Broadus addressed was that in I Corinthians 11:5f the apostle had spoken approvingly of women "praying and prophesying" in the public assemblies.51 From this fact it could be inferred that women are not forbidden to speak in the assembly, at least not absolutely. In this case, Broadus conceded the accuracy of the premise, but challenged the conclusiveness of the opponent's reasoning with a mildly complicated counter argument.

Broadus argued that the Apostle had made two apparently contradictory statements which must be reconciled, since actually contradictory statements in such immediate proximity to one another would be unlikely. Assuming that the Apostle did not contradict himself, the two passages may be reconciled by understanding the act of prophesying as an exception to the general directive stated in chapter fourteen. Prophesying, then, by women was allowed, but because prophesying was "inspired speaking" and because there is no inspired speaking in the 
present day, the permission granted by I Corinthians 11 is moot.

Both of the assertions by which he determined

I Corinthians 11 to be moot could be challenged. He anticipated one which argued from I Corinthians 14:3 that prophecy edifies; therefore, if a woman speaks to edify, whether speaking with "inspired speech" or not, she is exempt from the apostle's prohibition. This challenge he refuted by attacking the conclusiveness of the reasoning on grounds of a logical fallacy committed. He described the fallacy and illustrated it with an analogy as follows:

The author of this argument had forgotten the first elements of his logic, which certainly taught him that he must beware of assuming a proposition to be convertible. All prophesying was edifying speech; but how in the world can it be inferred that all edifying speech is prophecy? Yellow fever is a malarial disease; shall we infer that all malarial diseases are yellow fever? 52

In matters of form, Broadus followed whately's paradigm closely in refuting the third objection to his proposition. In so doing, perhaps he adequately refuted the contemporary claim to prophesying and other forms of edifying speech. Several of the propositions of his refutation were not supported, however, which weakened their

52 Ibid. p. 7. 
force.53 One obvious weakness of substance is that he failed to address the other primary provision of I Corinthians 11:5, namely, that women could pray in the assembly.

The fourth objection to the proposition was that the prohibition applied only in its historical and cultural setting at Corinth, where the generally loose behavior of the women in society required a particular strictness of Christian women in public places. 54 If the prohibition was thus culturally bound, then it would have no binding effect upon Broadus's contemporary audience.

This objection Broadus stated with full force, conceding that it was more plausible than those which had preceded it.55 Again, his method of refutation was to deny the premise with two contrary assertions. First, he observed that the same prohibition was made through Timothy to the churches in the region of Ephesus. Thus the command was not restricted to the women of Corinth. second, he argued that the basis for the prohibition as stated in I Timothy 2 was the facts connected with the

${ }^{53}$ Several of Broadus's interpretive assertions are not heavily supported. This is not to say that they are without basis, however, for evidence in their favor exists. His failure to present the evidence makes the arguments less satisfying.

${ }^{54}$ Broadus, "Should women speak. . ., pp. 7, 8 . 55 Ibid., p. 7 . 
creation and the fall of Adam and Eve. Based upon the second of these statements, he asked rhetorically, "Does not this absolutely forbid restricting his prohibition to Corinth and Ephesus, or to that particular age?"56

His refutation of the cultural argument was based upon the accepted principles of reformed hermeneutics, 57 namely, the consideration of the cultural and grammatical contexts of a proposition. Broadus would not deny that certain Biblical propositions are culturally conditioned and therefore are limited in their scope of application. His argument in this case was that the grammatical context, and its logic, established the proposition on transcultural grounds, and therefore made it universal in its scope.

The fifth and sixth objections, that the prohibition did not apply to women who have no husbands and that the documents of these two passages are corrupt, Broadus barely mentioned before dismissing them as desperate attempts to dislodge his proposition. 58 Both objections he

$$
{ }^{56} \text { Ibid., p. } 8 .
$$

${ }^{57}$ Reformed hermeneutics refers to the governing principles of Biblical interpretation followed by the Christian Reformers of the sixteenth century. Among these individuals were John Calvin and Martin Luther. Essentially, reformed hermeneutics rejects the fanciful interpretations of allegory in favor of a literal understanding of the Bible.

58 Broadus, "Should Women Speak. . . " p. 9. 
considered to be absurd, the former because it posed a ridiculous policy and the latter because no documentary evidence could be offered to substantiate the claim. In his dismissal of these objections, he applied whately's dictum that in refutation one should not pay great heed to inconsequential arguments, because to do so elevates their importance.

The seventh objection, found in the addendum, was that the Apostle Paul contradicted Jesus, who held women in high regard. Paul's statements, then, must have been biased and non-authoritative and therefore, non-binding for the contemporary audience. 59 As whately had urged, Broadus stated this objection full force, quoting extensively from a letter in which the objection was raised and acknowledging that the conclusion follows logically from the premise. 60

Broadus chose to refute this argument by showing the origin of the error, as whately had urged. He pointed out that the practice of women speaking in mixed assemblies had originated among the Methodists, and had been practiced by Quakers. Also Universalists and Unitarians, who did not acknowledge the authority of the New Testament, encouraged women to speak. The force of the argument was

$$
\begin{aligned}
& { }^{59}{ }_{\text {Ibid. }}, \text { pp. } 11,12 . \\
& { }^{60} \text { Ibid., p. } 12 .
\end{aligned}
$$


that the practice had not originated with Baptists, and was embraced by those who did not share in the Baptist loyalty to the authority of the Bible.

Although he employed a principle of form drawn from Whately, this refutation was weak. Correctly he framed the objection as being that the Apostle Paul's opinion was biased and non-authoritative. However, he failed to deal with that objection directly, which he could have done. For example, he could have challenged the line of reasoning which inferred that because women were important in the life of Jesus they should be permitted to speak in the mixed assembly. The conclusion does not follow the premises and is, therefore, fallacious. Had he established this point, he would have eliminated the objection that Paul contradicted Jesus. He also could have challenged the premise that Paul was not "inspired" when he wrote the texts involved from the well-developed theological doctrine of the inspiration of scripture. Why he did not present these arguments is not clear, but their absence clearly weakened his refutation of this objection.

The eighth and ninth objections were both based upon expedience. Respectively, they assert that the questioned practice should be allowed because it does much good, and that to reject the growing movement favoring the practice 
would be to concede its benefits to others.61 The following statement expresses the former objection well:
A justly honored Baptist pastor was not long ago reported as saying (in substance) that he did not want to hear so much about texts on this subject; the thing does good, and that was enough for him.62
Broadus replied to this objection using indirect means, which whately had described as using the opponent's own premises to prove an absurdity. His argument, quoted below, assumed the premise that a good outcome justifies the means by which it is obtained, and then extended the premise to an objectionable conclusion.

The Paedobaptists do much good. Many devout Romanists gain good and do good by holding up a crucifix to dying eyes; does that make the practice scriptural and justifiable for Baptists? Why will not Baptist people see the gross inconsistency of vehemently asserting the necessity of conforming to the New Testament in regard to church membership and the ordinances, while they coolly disregard express prohibitions in respect to another matter?63

To the objection that other groups would benefit from the growing movement if Baptists did not accommodate the practice in question, Broadus employed an argument similar to that used to refute the previous objection. Again, he assumed the premise and extended it to an undesirable conclusion.
${ }^{61}$ Ibid., pp. $14,15$.
62 I bid. p. 14.
63 Ibid., pp. $14,15$. 
"Ah, but," some will say, "this is a great movement; and it is going to grow. Shall we let the Methodists get all the benefit of it?" Grant for the sake of argument that it seems expedient, and will give denominational power. We let the Methodists get all the benefit of infant baptism, of Arminian theology, of centralized organization, because we think these things are contrary to the New Testament. If Baptists are going to abandon New Testament teachings for the sake of falling in with what they regard as a popular movement the very reason for their existence has ceased.64

In both cases he conformed to the whately paradigm. He also developed materially convincing arguments by appealing to the highest of distinctive Baptist principles.

\section{$\underline{\text { Summary }}$}

In this discourse, Broadus conformed consistently to the paradigm of whately. He was aware that presumption favored his proposition, and he confessed that he appreciated that advantage in addressing a controversial subject. Although it was contrary to his own view regarding burden of proof, he apparently did not feel obligated to prove his proposition, confining his argumentation to refuting objections.

In every one of his refutations, specific dicta from Whately's notions of refutation are followed. Thus, in matters of form, his arguments conformed to the paradigm. The third and the seventh objections were not refuted as

64 Ibid., p. 15. 
well as they could have been. The absence of certain available arguments weakened his case at those two points. often in this discourse Broadus made assertions concerning interpretive matters with little support. For example, concerning the definition of the word "speak" in the first objection he developed an argument from testimony, citing an authoritative opinion on the interpretive matter. However, only in that instance did he quote such an authority. In his refutation of the third objection, his assertion that "to prophesy" referred to inspired speech seemed arbitrary, because no support was presented. It must be acknowledged that some and perhaps many of his statements were not proven as they might have been. It must also be acknowledged that Broadus himself was a scholar both of the New Testament and the Greek language, in which it was originally written. At the age of 63 , he had earned the respect of both scholars and laymen for his opinions. Thus, the entire address bore the imprint of his expert testimony.

In substance, then, the arguments in this discourse are somewhat uneven in quality. Some of the objections were handled reasonably well, but others were not convincingly refuted.

It is significant that Broadus apparently followed Whately's approach to presumption and burden of proof rather than his own in this discourse. Rather than 
proving his proposition, as his own view of burden of proof would require, he asserted it as the teaching of the New Testament on the subject, and then proceeded to refute objections. In this he followed whately's notion that if presumption favors one's proposition, he need only refute objections for the statement to stand. He also implicitly claimed presumption in his favor, both from the authority of the Bible and from the bias of his intended audience. In the refutation of arguments, he consistently followed several of Whately's ideas, as demonstrated above. The major weakness of his refutations was that they were not thoroughly supported.

"Immersion Essential to Christian Baptism"

Background of the Discourse

In the first address examined in this chapter, Broadus urged that Baptists should teach their distinctive views, because they owed as much to Christians of other denominations. Dr. Broadus followed his own admonition in this discourse, in which he argued that the correct mode of baptism is immersion.

Like the second discourse studied, this one was written rather than oral. It was published in pamphlet form in 1892.65 As in the present day, most Christian

\footnotetext{
${ }^{65}$ Starr, 3:151.
} 
denominations in 1892 practiced baptism either by sprinkling or by pouring. Broadus chose to speak to this issue from the Baptist perspective, urging the practice of immersion.

Unlike the other two, this discourse was written for a non-Baptist audience. Internal evidence clearly indicates as much. This evidence will be presented and discussed below, with regard to presumption and burden of proof. Although the audience was not Baptist, it was assumed to be Christian, as the overview below indicates.

An Overview of the Discourse

This discourse is almost entirely argumentation centered on the proposition that immersion in water is essential to Christian baptism. Of the three addresses examined in this study, this one is the most thoroughly developed from the standpoint of argument. It is also the longest of the three.

The proposition is stated in the first sentence of the document and is followed by some qualifying development. Particularly important in this regard was Broadus's immediate appeal to the authority of the Bible. He also asserted that the discussion was not simply an inconsequential matter of form, but rather an issue of the nature of the practice.

Having established the preceding suppositions, 
Broadus proceeded to prove his proposition. His argument was threefold: 1) the obvious sense of the Bible, as conveyed in its descriptive accounts of the practice, favors immersion; 2) the lexical definition of the term baptizo favors immersion; and 3) the practice of the Greek church favors immersion. Two objections are addressed in this section of the discourse.

Satisfied that he had adequately established his proposition, Broadus next undertook the refutation of five primary objections. These were the following: 1) the church has authorized a change from the New Testament mode of baptism; 2) Christian liberty permits one to choose the outward mode as long as the significance is unchanged; 3) practical constraints often make immersion undesirable if not impossible; 4) the Biblical use of baptizo permits other understandings than immersion; and 5) the term bapto involves immersion, but baptizo means "to put within."

Broadus ended his discourse with a plea for crossdenominational Christian unity, both in spirit and in organization. He insisted, however, that such unity required that Christians take the Bible as their sole authority and understand it in its plain sense. And, if this understanding of the Bible were adopted, differences regarding the subject of baptism would be eliminated. 
An Analysis and Assessment of the Discourse

once again, the whately paradigm will be used as the standard of analysis and assessment of this discourse. Presumption and burden of proof will be discussed first. Then the arguments identified in the overview will be individually examined. The writer will discuss forms of argument and refutation together so that the order of Broadus's discourse may be preserved.

Presumption and Burden of Proof

Unlike the other two discourses, which were addressed to Baptist audiences, this discourse was addressed to a broad christian audience. Internal evidence makes this fact obvious. In the introductory comments affirming the sole authority of the Bible, Broadus probably had in mind christians from other denominational traditions in his audience when he said:

We cannot acknowledge any other authority. The opinions and practices of eminent Christians in past ages, yea of our own best friends, our pastors, our parents must not be regarded, except so far as they may help us to determine what is taught on the subject in the Scriptures. 66

More clearly, in his concluding remarks it is evident that he was thinking of many non-Baptists. He said:

I have spoken long and earnestly of a controverted question, one of those which divide Christians.

66 John A. Broadus, "Immersion Essential to Christian Baptism" (Philadelphia: The Bible and Publication society, n. d.), p. 4 . 
But I am a rejoicing believer in Christian Union. - All who are truly his are one in him. Not only those belonging to what we call evangelical denominations, but many Romanists, for there are doubtless lovers of Christ among them, as there have been in past ages; and many of the Greek Church; and perhaps some Universalists, and Unitarians, possibly even Mormons ${ }_{67}$ and Quakers who reject all water baptism... 67

Although members of other denominational groups are not directly addressed, the conciliatory tone clearly implies that his aim was to persuade those of other denominations to adopt his viewpoint. His final appeal, which followed the statement above, clearly indicated his intent. He said:

All Christians, except the Quakers, make baptism a condition of church membership. And for the sake of a more complete and efficient Christian union, we urge upon our fellow Christians, as the plain teaching of God's word, that there is no baptism where there is not an immersion. ${ }^{68}$

Concerning presumption, Whately had said that the biases of an audience may determine the side of a question upon which presumption falls, and conversely, that presumption is against that which is paradoxical or contrary to prevailing opinion. It was determined above that Broadus's audience included Christians of all denominations. It follows, therefore, that presumption was not in his favor, for the groups other than his own practiced either sprinkling or pouring as the mode of baptism. In

$$
\begin{aligned}
& 67 \text { I bid., pp. } 64,65 . \\
& { }^{68} \text { Ibid., p. } 66 .
\end{aligned}
$$


terms of the paradigm, Broadus's proposition was contrary to the prevailing opinion of his intended audience.

One aspect of presumption, as whately defined it, Broadus did apply. In his introductory comments, he applied the notion of the habitual presumption in favor of the judgments of the Bible. 69 As the following statement indicates, he believed that his claim to presumption for the authority of the Bible would be upheld by his audience.

To insist on the scriptural act of baptism is a necessary consequence of a great fundamental principle, which was once held by Baptists almost alone, but which many of our brethren of other connections are now coming to share-the exclusive authority of scripture. We do not say simply the authority, nor the paramount authority, but the exclusive authority of Scripture. Baptism is performed at all, simply because the Scriptures direct us to perform it; therefore we feel bound to inguire what it is that they direct, and to do
that.

It is also clear from the final sentence of the statement above that this presumption was foundational to the argument to follow.

on one hand, then, regarding the authority of the Bible, presumption may have favored Broadus. On the other hand, prevailing opinion concerning the specific issue in

${ }^{69}$ This element of presumption has been explained previously.

${ }^{70}$ Broadus, "Immersion Essential. ..," pp. 3, 4. Emphasis mine. 
question opposed the Professor's proposition. Because the habitual presumption in this case is less directly and specifically related to the issue than the presumption of prevailing opinion, the latter is probably the stronger. Therefore, the writer concludes that presumption was not in Broadus's favor in this case.

According to whately, the burden of proof rests with the one who disputes presumption. If the conclusion stated above concerning presumption is correct, the burden of proof in this discourse rested with Broadus. Broadus did, in fact, assume this burden, developing three 1 ines of argument in support of his proposition and refuting objections to it. It cannot be determined, however, that Broadus assumed the burden in keeping with whately's views. It must be remembered that. Broadus's own belief was that he who alleges must prove. Because he alleged that immersion is essential to Christian baptism, he placed upon himself the burden of proof apart from any consideration of presumption.

Analysis of Arguments

As indicated in the overview above, Broadus offered three lines of argument to establish his proposition, and then addressed five objections to his proposition. First the affirmative arguments will be examined, followed by consideration of the refutation of objections. 
Affirmative Arguments. Broadus's first affirmative argument was that the obvious sense of the New Testament references to the practice is that of immersion. Given as examples are the baptisms of Jesus and the Ethiopian eunuch, both of whom are said to have come up out of the water after being baptized. Also cited is Romans 6, in which baptism is likened to burial. The Professor's point was that the descriptive narrative accounts and the imagery of burial all indicate that the New Testament practice was to immerse.

Broadus anticipated an objection to his interpretation of the baptism of Jesus, for the literal translation of Matthew's account of the event states that Jesus came up from the water. From this premise, one could infer that he had not been in or under the water. Conforming to Whately's standard, Broadus challenged the validity of the premise, noting that Mark's account of the event said that Jesus came up out of the water. He also appealed to the expert testimony of the translators of the Tyndale, Cranmer, Geneva, and King James versions of the Bible, all of whom translated Matthew's term "out of." In addition, he demonstrated from other uses of the term "from" the similarity of the two ideas. For example, he observed that to take a mote from the eye of another is to take it out of that one's eye. 
To summarize and reinforce his first argument, Broadus related two personal incidents which illustrated his point that the obvious meaning of the New Testament narratives supports the notion of baptism by immersion.

This first 1 ine of argument clearly conforms to the elements of Whately's theory included in the paradigm. First, insofar as he perceived a presumption of the authority of the Bible to be in his favor, he pressed it to his advantage. Only upon such presumption would the narrative accounts cited be considered as normative for contemporary practice. Second, the objection that Jesus came "from" the water was raised immediately after it was asserted that he came "out of" the water. The objection was refuted, in fact, before the other two affirmative examples were presented. Thus, in his placement of the objection, Broadus was consistent with whately's dictum that refutation should be done near the beginning rather than at the end of an argument.

In substance, the refutation conformed to three of Whately's ideas regarding argument from testimony. The reference to several translations may be considered a form of argument from testimony in that these expert linguists and interpreters expressed an interpretive judgment in their translation of Matthew's account of Jesus' baptism. Whately would agree that their witness in a matter of opinion is credible because they have the recognized 
ability to form an intelligent judgment concerning the question. Such an argument is further strengthened, according to whately, if it counters the witness's prejudice. Broadus explicitly pointed out the bias of his witnesses, writing:

Does some one think our friend's translation has misled him on this subject? That would be strange, for the translation certainly was not made by Baptists. . . The translation he reads, our cherished Bible, was made by Episcopalians, members of the Church of England. 71

Third, whately asserted that the argument from testimony is made stronger by increasing the number of witnesses. This Broadus accomplished by quoting four translations rather than one.

The second affirmative argument was that the New Testament term baptizo, which is translated "baptize," requires immersion. In establishing this assertion, Broadus again employed heavily the argument from testimony in a manner quite consistent with Whately's theory. Before introducing the testimony he would use, Broadus articulated the principles by which testimony must be judged. His statements are remarkably like those of Whately:

It is a question of scholarship. Therefore we ought to ask those who are unquestionably able and leading scholars. And they ought to be as nearly as possible disinterested as to the matter in

${ }^{71}$ Ibid., p. 1l. Episcopalians and Anglicans practice sprinkling as their mode of baptism. 
hand. Such are the conditions required when we refer any matter whatever to the decision of others. 72

Before he presented the evidence, Broadus carefully stated the credentials of each of the scholars whose writings would testify to his viewpoint. ${ }^{73}$ After he presented his arguments, he again emphasized that the sources he had employed met the criteria of acceptable testimony. He said:

Such is the rendering of this word by the three most recent lexicons of acknowledged scientific value; the three which any competent scholar, if asked to recommend lexicons to a student of New Testament Greek, would be sure to name. I might add that the two German commentators on the New Testament, who are the foremost of the century as to full and accurate scholarship, Fritzsche and Meyer, furnish like testimony as to the meaning of
the word. 74

Broadus anticipated an objection to this argument, namely, that some lexicons also define the term to mean "pour" or "drench." From such definitions one could infer that modes other than immersion are permitted by the word

72 Ibid., p. 12 .

${ }^{73}$ It is particularly significant that in stating the credentials of Liddell and Scott, whose lexicon he would quote, he noted that they were scholars of the Church of England.

74 Broadus, "Immersion Essential..." p. 14. In the argument itself, Broadus quoted three lexicons:

1) Liddell and Scott's Lexicon of the Greek Language;

2) Grimm's edition of Wilke's Lexicon of New Testament Greek; and 3) Cremer's Biblico-Theological Lexicon of New Testament Greek. All of these concurred that the sense of baptizo is "to immerse." 
baptizo. Broadus conceded the premise that such definitions are included in some lexicons. Conforming to Whately's dictum that one may deny the conclusiveness of another's reasoning in refutation, he argued that in the cases in which the term is used of pouring or drenching it is used in a figurative sense. He also asserted a principle of interpretation, which requires that the primary sense of a term 75 be used unless the context requires a remote or secondary sense. These two counter-assertions decrease the probable validity of the opponents' contention that baptizo means "pour."

Whately suggested concerning refutation that sometimes one will prefer to establish his own position before refuting objections. Should this be the case, one should make clear his intention to return to objections raised. Broadus, in concluding his treatment of the second affirmative argument, acknowledged that further objections to his conclusions drawn from lexical studies existed. These he promised to answer later in his discourse. This promise he fulfilled in treating the fourth objection, which will be discussed at an appropriate point below.

The third affirmative line of argument was that the Greek Church practices immersion, because they understand term.

${ }^{75}$ In this case, immersion is the primary sense of the 
the Greek term baptizo in that sense. As before, Broadus cited the testimony of individuals versed in the Greek language, who testified that the term in question involves immersion. He quoted one Greek scholar, who said:

The Church of the west commits an abuse of words and of ideas in practicing baptism by aspersion, the mere statement of which is in itself a ridiculous contradiction. 76

Having presented the three lines of argument described above, Broadus was satisfied that he had adequately proven his proposition. He expressed this belief through the words of the imaginary inquirer whom he had led through his arguments:

Such, then, is the evidence which may be given our unlearned friend from scholars, the lexicons, and the living Greeks, concerning their own word. Much more might be added in the way of confirmation; but he would probably say, "Well, it is plain that I can trust my English Bible. What these great scholars say--none of them Baptists-and what the living Greeks say and do, accord exactly with the impression I got from my own Bible; and so the evidence is enough; I care for no more."?7

Refutation of Objections. Believing that he had met his obligation to bear the burden of proof, Broadus next raised and refuted five objections to his proposition. He did not call them objections, but instead referred to them as grounds upon which Christian people defend the practice

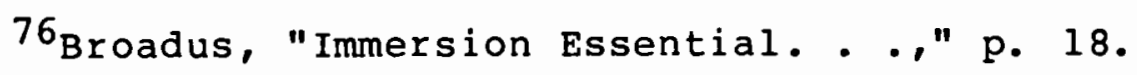
$77^{\text {Ibid. . p. } 19 .}$ 
of sprinkling for baptism. 78 Regardless of what they are called, the propositions he refuted were functionally objections. These will be treated briefly.

The first objection Broadus addressed was that although the New Testament required immersion, the church authorized a change. This notion he refuted by tracing the origin of the error, according to the dictum of Whately. The practice was begun in the third century to be applied in cases of sick and dying individuals. It was not until the thirteenth century that sprinkling was used in all cases. Broadus argued that the earliest use of this "clinic" baptism arose from an exaggerated sense of the importance of the practice, for people were afraid to die without having been baptized.

He further refuted the notion using argument from testimony. He cited the Reformers, Luther and Calvin, who had called for a return to the practice of immersion. ${ }^{79}$ Again, he selected witnesses who, in matters of opinion, were considered capable of forming a credible judgment. The second objection was that the significance of baptism is that which should be maintained, and the mode should be left as a matter of liberty, or individual preference. In this case, Broadus challenged the premise

78 Ibid., p. 20.

${ }^{79}$ Ibid., pp. $22,23$. 
that the significance of the practice is all that matters. Using the indirect approach described by whately, he extended the premise to support the Quaker assertion that baptism is unnecessary altogether, because the spiritual significance exists quite apart from the act. Such an extension is unacceptable to one who practices baptism in any form. Broadus had expressed this line of argument in conversation with an Episcopalian, which he related in the discourse as follows:

They say Christians may choose for themselves about mere outward forms; these make no difference if you have the essence of the thing. Yes, and so says the Quaker, more strongly still. What would you say to the Quaker? I asked this question of an esteemed friend, who is an Episcopal clergyman. The Quaker tells us the mere outward form of baptism is unnecessary; the essential thing is to have the baptism of the spirit, and water baptism need not be observed at al1. What would you say to him? "I would tell him the Scripture teaches us to baptize in water." Very well, I replied, and so it teaches us to baptize in water. If you have an outward ceremony at all, you have a form, and can you say that the form of a ceremony is of no importance? How will such an one answer the Quaker, except upon the Baptist principle? 80

The third objection Broadus answered was actually a series of five practical difficulties attendant to baptism by immersion. Among these were that it can be dangerous to the ill or feeble, it can result in indecent exposure, it may be impracticable, and that many good people have

$$
{ }^{80} \text { I bid., pp. } 26,27 .
$$


believed in and been blessed by the practice of sprinkling. In each of these cases the professor challenged the premise of the argument as insufficient to merit justification for an alternate mode of baptism, using various forms of argument. For example, to refute the notion that immersion can result in indecent exposure, Broadus used an argument from analogy. He observed that when a lady alights from her carriage, there is danger of indecent exposure, unless proper care is exercised. Just as indecency in that circumstance can be avoided by taking proper precautions, so also can indecency in the act of immersion be avoided by careful planning and management. To refute the notion that sprinkling has been used and defended by good people, he again employed the indirect approach of extending the premise to an unacceptable conclusion. He did this by selecting various denominational groups and asking rhetorically why they rejected certain doctrines of other denominations. The doctrines they rejected, he reasoned, have been held and defended by some of the greatest Christians and intellects of the human race.

Like the third objection, the fourth was actually a series of five challenges to Broadus's claim that the New Testament meaning of baptizo is "immerse." Earlier in the discourse he had promised to address further his assertion that the New Testament word cannot be used to 
justify modes other than immersion. His treatment of this objection fulfilled that promise.

Primarily, the objection concerned various passages of Scripture which some understood to describe pouring or sprinkling. To refute the interpretations which countered his proposition, he used the techniques of argument which have been described earlier in this study.81 Two representative examples will be suffice to demonstrate Broadus's dependence upon whately in this rather lengthy section of the discourse.

First, there was the notion proposed by Dr. Edward Beecher that, according to John 3:22-25, baptism is synonymous with purification. Such an idea is based upon the textual statement that a discussion of purification arose, based upon several acts of baptism. The text reads:

After these things Jesus and $\mathrm{His}$ disciples came into the land of Judea; and there He was spending time with them, and baptizing. And John also was baptizing in Aenon near Salim, because there was much water there; and they were coming and were being baptized. For John had not yet been thrown into prison. There arose therefore a discussion on the part of John's disciples with a Jew about purification.

${ }^{81} \mathrm{All}$ of the arguments offered cannot be treated here, due to limits upon the scope of this study and length of the discourse. Two examples have been given to demonstrate Broadus's use of Whately's elements. The reader interested in further analysis may examine pp. 3555 of the discourse.

$$
82 \text { John } 3: 22-25 \text { (NASB). }
$$


Broadus conceded that baptism was understood to be a rite of purification, and that the passage in question clearly teaches that a discussion of purification very naturally was precipitated by acts of baptism. However, he argued, one cannot infer that baptism is therefore synonymous with purification. He said:

The fact that baptism was going on might very naturally lead to a discussion between some of John's disciples and a Jew about the general subject of purification, and the relation of this to other purifications. Being a peculiar, remarkable, and novel purification, it was perfectly natural that baptism should lead to discussion of the general subject. But why in the world are we to say that the terms baptism and purification are synonymous, that baptism means nothing more definite than purification, and that any form of purification might be called a baptism? 83

Broadus's argument is obviously that the inference is far broader than that which is warranted by the particular from which it is drawn. To support his contention, he set forth an argument from analogy:

Suppose a murder has occurred, and leads some persons into a discussion concerning death; are we to conclude that the terms murder and death are synonymous, and that any form of death may be called a murder? Yet because the occurrence of baptism led to a discussion concerning purification, we are told that these terms are synonymous, In the Professor's argument, Whately's contention that an analogy rests upon the relationship of ratios is obviously

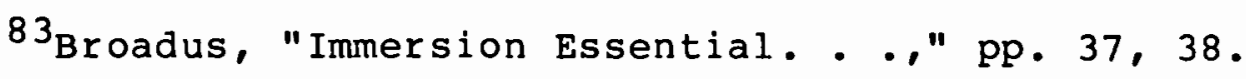
84 Ibid.., p. 38. 
applied. No comparison is intended between murder and baptism or death and purification. Rather, his point was that just as an act of murder might lead to a broader discussion of death, so also an act of baptism might lead to a broader discussion of purification. However, just as all deaths are not murders, neither are all purifications baptisms. That the analogy emphasized the relationship is unmistakable because the entities compared, i. e., murder and baptism, are quite unlike each other.

A second example involves the objections based upon testimony regarding the Jordan River. On one hand, Broadus cited testimony that the river is too shallow to permit immersion. On the other hand, he reported testimony that the bank is so steep and the current so swift that immersion would be impracticable.

Whately had said that regarding matters of fact, the witness's honesty, accuracy, and means of obtaining information must be considered in evaluating testimony. Further, he urged that a witness's prejudice must be considered. Broadus employed both of these elements in his refutation. The view that the bank was too steep and the current too swift had been asserted by one who had visited the traditional place of Jesus' baptism. Therefore, Broadus implied, this individual could testify concerning the matter based upon first-hand observation. such a means of obtaining information should be reasonably 
accurate. Although he disclaimed intent to impugn the character of this witness, the professor pointedly challenged the accuracy of the testimony. He charged:

Now this gentleman perfectly knew that every Spring, when the river is high as he saw it, in the week preceding Easter, there come four or five or seven or eight thousand pilgrims from all parts of the East to this very place,... and there - . do actually immerse themselves and one another in the river--not as a baptism (for they have received that in infancy), but as a sacred bath at that holy spot. He knew as well as I do that this happens every spring at that very place, and yet it never occurred to him to connect that fact in his mind with his own timid notion that immersion would there be impracticable. I am satisfied he was a good man, and have no idea he meant to deceive, but how strangely gogd men can sometimes manipulate their own minds. 85

The statement not only alleges inaccuracy in the testimony, but also attributes that inaccuracy to prejudice which, in Broadus's opinion, prevented the witness from drawing an accurate conclusion.

The fifth and final objection to his proposition was a novel view proposed by a Presbyterian clergyman. This view involved a distinction of terminology, namely, that bapto means "dip," but baptizo means "put within." The former word would require that an object (or person) be put in water and quickly taken out again, whereas the latter would leave the object or person there.

$$
{ }^{85} \text { Ibid., pp. } 39,40 .
$$


Broadus's first line of refutation was to employ Whately's indirect approach, drawing a ridiculous conclusion from the premises. This form of reductio ad absurdum rather humorously points out the foolishness of the notion:

Suppose it were granted that this was true; then we should have Christ commanding us to put men within or under the water, as a religious ceremony, and, because he does not expressly add that we are to take them out again, we should be bound, forsooth, to let them remain there. If any of $m y$ esteemed brethren of other denominations should take this view of the matter, and request me to "intuspose" them, to put them within the water, in the name of our Redeemer, it may be assumed that my common sense and humanity will cause me to take them out again, as their own common sense and prudence will then lead them to go off and change their garments, without needing an express command in either respect. 86

He further refuted the opponent's view by denying the accuracy of his premise, namely, that a distinction of meaning is to be made between bapto and baptizo. He accomplished this denial with the counter-assertion that commonly in language a strengthened form of a word gradually replaces a weaker form without a substantial change of meaning. Although the two words did not become identical in meaning, he said, the stronger came to be frequently employed in the same sense as the weaker.87

$$
\begin{aligned}
& { }^{86} \text { Ibid., pp. } 57,58 . \\
& { }^{87} \text { Ibid., p. } 61 .
\end{aligned}
$$


The argument at this point is rather complex and seems to be more involved than the novel approach he attempted to refute merited. Broadus noted that the view was gaining a following, which probably explains why he devoted such attention to it. Perhaps, however, he violated whately's dictum, which urged that one pay little heed to insignificant arguments, lest undue attention elevate their importance.

\section{Summary}

of the three discourses studied, this one was not only the longest, it was also the finest specimen of argumentation, according to whately's paradigm. Concerning presumption and burden of proof, Broadus did not enjoy the former and, therefore, bore the latter. A significant portion of the discourse involved proof of his proposition. He probably assumed the burden of proof upon his own premise that he who alleges must prove rather than following Whately's dictum that the burden rests upon the one who challenges presumption. However, his arguments to establish his proposition are far more carefully framed in this discourse than in the other two. If, by his principle, he believed that he had assumed the burden of proof in the other two discourses, one might ask why in this one his arguments were so much more extensive. 
His refutations regularly followed whately's principles. All of those included were too numerous to discuss above. Those presented, however, are a fair representation of Broadus's approach.

It is significant to note a similarity and a difference between this discourse and the first one studied. In both discourses, the proper mode of Christian baptism is an issue. In the first, it was a subordinate proposition whereas, in this one, it is the central issue. In the first, very little argument was offered to establish the proposition. This may be because baptism was not the central issue, but the more likely reason is that the first audience agreed with Broadus concerning the subject at the outset. In this third discourse, the arguments are far more thorough, probably because Dr. Broadus did not expect the third audience to concur with his view. Clearly this pamphlet was intended to persuade a broader Christian audience of another point of view.

\section{Conclusion}

The purpose of this chapter has been to investigate how and to what extent John Broadus applied Richard Whately's theories in three of his own addresses. Employing a model for critical discourse proposed by Lawrence Rosenfield, the author constructed a paradigm which includes elements of Whately's theory. Criteria 
developed required that elements of the paradigm, first, must be found both in Whately's Elements of Rhetoric and in Broadus's Treatise on the Preparation and Delivery of Sermons and, second, must be in the opinion of contemporary experts, whately's most significant contributions. The paradigm included the following elements: presumption and burden of proof, arguments from testimony and from analogy, and refutation of objections.

Three of Broadus's discourses were analyzed according to the provisions of the paradigm. They were studied in chronological order, which happened to coincide with a progressive order, namely, that both the quantity and quality of argument presented increased with each subsequent discourse. This dual increase may be explained in terms of whately's ideas.

The first address was presented to a Baptist audience and concerned a subject to which there could be little objection. The speech emphasized Baptist traditions, both in belief and practice. In terms of whately's conceptions, presumption was clearly in Broadus's favor and there were few objections to be raised and refuted with that audience. The greater need of the audience was motivation rather than persuasion, and so there is greater emphasis upon appeal than upon argument. Because the paradigm is limited to only a few aspects of argument, 
much of the development of this speech cannot be judged by it.

The second discourse was also intended for a Baptist audience, but involved a more controversial subject. Presumption favored Broadus, in that the majority of his audience shared his opinion. However, he admitted several objections to his proposition, so that the greater part of the discourse was given to refutation of them. The number of objections, properly admitted and refuted, account for the increase in quantity and quality of argument, as compared to the first address studied.

Concerning burden of proof, it seems to this writer that Broadus did not follow his own notion that he who alleges must prove. To establish the proposition, he merely asserted that the obvious sense of the two New Testament passages which he quoted clearly prohibited women from speaking in mixed assemblies. The only argument following the proposition was the refutation of objections. Thus, his practice conformed to the dictum of Whately, namely, that if presumption favors one's proposition, he need only to refute objections to it in order to maintain it. It could be argued that he assumed the burden of proof and offered, in his opinion, sufficient support for the proposition to satisfy his audience. If he did assume the burden, then he may be faulted for 
failing to build a convincing case to establish his assertion.

The third address was longest and contained the most involved argumentation. This almost certainly was due to the fact that Broadus's audience was not primarily Baptist, and therefore would not grant presumption in favor of his proposition. Although he claimed habitual presumption for the authority of the Bible, it is apparent that he conceded presumption concerning the specific issue addressed. He therefore offered relatively extensive arguments to establish his assertion. Rather than simply asserting his interpretive views as he had tended to do in the other discourses studied, he carefully argued support for them. He also went to great lengths to refute objections, particularly those involving interpretation of the Biblical data.

In the previous chapter, the writer discussed the unmistakable influence of Whately upon the theory of John Broadus. In this chapter he has examined that influence upon Dr. Broadus's practice. This examination has disclosed clear evidence that Broadus applied elements of Whately's theory in his speeches and discourses. Generalizations must be drawn cautiously from such a limited number of specific examples, but at least in these three discourses, Whately's influence cannot be denied. 
CHAPTER V

CONCLUSION

\section{Summary}

An understanding of argument is essential to an understanding of rhetoric. It is through argument, among other forms of proof, that one convinces an audience that a given proposition is valid. At least since the time of Aristotle, who wrote extensively concerning proof by means of argument in his Rhetoric, theorists have discussed the subject.

Argument is important not only to rhetoric in general, but to preaching in particular. Therefore, various homileticians have discussed the application of argument theory to preaching. Two of these theorists, both from the nineteenth century, have been the subjects of this study: Richard Whately, the Anglican Archbishop whose Elements of Rhetoric was published in 1828 and John Broadus, the Southern Baptist educator and preacher whose Treatise on the Preparation and Delivery of Sermons was published in 1870.

The purpose of the study has been to trace the influence of whately's theory of argument upon the theory 
and practice of Broadus. This purpose was accomplished as described below.

The study began with a brief background study of Richard Whately and a selective description of his theory of argument. Elements were chosen for discussion, either because they were original with whately or because they represented, in the opinion of experts, a significant development of ideas previously created.

Included in the discussion were the elements of presumption and burden of proof. These notions, known in Roman and English law, were introduced into the field of rhetoric by whately. He defined presumption as a preoccupation of ground rather than as a preponderance of probability in favor of a given proposition. He believed it to be essential at the outset of an address to determine where the presumption lies, for the burden of proof, he said, rests with the side disputing the view favored by presumption. Presumption, in his view, favors existing institutions, the innocence of those accused of wrongdoing, tradition, and individuals, bodies, or books which command deference. Presumption is also determined, he noted, by audience prejudice concerning a proposition.

A second major contribution discussed was the Archbishop's theory of refutation. Following the classic theorists, Whately noted that there is not a distinct class of refutatory argument. Rather, he said that regu- 
lar argument forms may be employed in refutation. He explained several ways one can refute propositions and objections.

Also discussed in the second chapter were whately's notions of argument from analogy and argument from testimony. An argument from analogy is based not upon similarity of the essence of the analogues, but rather upon their relationships to some other thing or things. An argument from testimony is based upon a witness's statement of a fact or an opinion. Such an argument, according to Whately, does not conclusively prove anything since it can be falsified. However, its relative weight may be determined by considering several conditions related to the testimony. Among these conditions are the witness's ability to know the facts or form an opinion concerning a matter, his own bias concerning that to which he testifies, and the number of witnesses who concur in their testimonies.

The third chapter included a background study of John Broadus and a selective presentation of his theory of argument. The ideas treated are among those influenced by Whately.

Comparison of the two theories disclosed that Dr. Broadus closely followed Archbishop Whately's notions regarding refutation of arguments and argument from analogy. Broadus approached argument from testimony in a 
slightly different fashion, however, distinguishing between testimony and authority. The former, he said, applies to matters of fact, whereas the latter applies to matters of opinion. Concerning the use of argument from testimony in matters of fact, the Professor followed Whately quite closely. In his discussion of authority and matters of opinion, he employed the notions of other theorists. It was in his development of the concept of authority that Broadus discussed his view of the authority of the Bible. Although whately had not made the distinction Broadus followed, his ideas concerning the authority of the Bible were similar to those of Broadus and have been cited as the reason for his emphasis on testimony in the Elements of Rhetoric.

In the matters of presumption and burden of proof, Broadus disagreed pointedly with Whately. Broadus preferred to distinguish between legal and rhetorical definitions of presumption. Believing that only the latter sense was relevant for his purposes, Broadus defined presumption as predisposition concerning a given proposition. A related difference of opinion between the two men involved the relationship of presumption to burden of proof. Broadus argued that it is useful for a speaker to know the predisposition of his audience, but that in rhetoric, presumption has no bearing on placing of the burden of proof. Whately had stated that presumption 
determines the placement of the burden of proof. Unlike the Archbishop, Broadus believed that he who alleges bears the burden of proof, regardless of presumption.

In Chapter Four, a paradigm for rhetorical analysis was developed. The paradigm included the elements of Whately's theory for which he is best known and with which Broadus interacted. Included in the paradigm were presumption and burden of proof, arguments from analogy and testimony, and refutation.

The paradigm was applied to three of Broadus's discourses, namely, "Duty of Baptists to Teach Their Distinctive Views," "Should Women Speak in Mixed Public Assemblies?" and "Immersion Essential to Christian Baptism." The addresses were studied in chronological sequence, which happened to coincide with a progressive sequence. One progression was from a strong presumption in favor of Broadus's proposition in the first address to a presumption against his proposition in the third. A correspondent progression was from limited argumentation in the first address to extensive argumentation in the third. As one might expect, uses of Whately's elements were discovered in all three discourses. Broadus closely followed the Archbishop in matters of refutation, argument from analogy, and argument from testimony. Concerning presumption and burden of proof, only in the third discourse did Broadus offer substantial argument to establish 
his proposition. In so doing, he conformed to Whately's dictum that if presumption favors one's proposition, the burden of proof rests upon the other side. Satisfactory refutation of objections is all that is required to allow the proposition to stand. Particularly in the second discourse there is little evidence that Broadus followed his own notion that he who alleges bears the burden of proof.

\section{Conclusions}

One aim of this study was to determine the contemporary usefulness of Whately's and Broadus's theories of argument for public speaking in general and preaching in particular. Conclusions pertaining to this aim will be discussed below.

Before conclusions are suggested, some limitations which condition the conclusions of the study must be stated. First, the paradigm used for analysis is limited in its scope, for it included only selected elements of Richard Whately's theory of argument. Therefore, it cannot account for all argumentative materials in a discourse compared to it.

Second, only the variables of the message the source of the message were considered in the paradigm and the analysis based upon it. Rosenfield noted that the environment and the critic are two other variables opera- 
tive in any rhetorical event. The practical validity of the theory could have been better judged if the effects of the discourses, when they were delivered, had been studied.

Third, the nature of the study is, in part, descriptive. It is difficult to draw prescriptive conclusions from descriptive studies with any degree of certainty. The fact that a particular rhetorical theory has been created and practiced in the past does not prove that it is either valid or effective in the present.

Fourth, only three discourses were studied. Upon such a limited sample, it is unwise to draw conclusive generalizations concerning either the general usefulness of the theory of argument involved or Broadus's application of it.

The limitations noted restrict one from drawing independent conclusions. Conclusions may, however, confirm or modify the opinions of others who have examined the theories and drawn conclusions concerning them.

Conclusions have been suggested previously concerning the extent to which Broadus was influenced both in theory and in practice by whately's theory of argument. The findings reported in chapters three and four suggest that Broadus considered Whately's notions to be useful for preaching, particularly when controversial subjects are involved. 
Expert opinion, cited elsewhere, noted the lasting contributions of whately. He recognized the need to establish the truth of a proposition by the governing rules of $\log$ ic, which he knew well. He also realized that a good argument must convince an audience. Combining these two notions, whately produced a practical, psychological, audience-oriented rhetoric. His extensive discussion of refutation and arrangement of arguments reflect his audience awareness.

Whately's work has also been applauded for its ecclesiastical usefulness. He assumed that principles of argument may be used to establish and support doctrines of the Christian faith. In his Elements he demonstrated this use. Certainly this study has confirmed this usefulness, for the three discourses studied here were directed toward religious audiences. Broadus's use of argument from testimony and deference to Biblical authority particularly tends to confirm this opinion.

Concerning the matters of presumption and burden of proof, Broadus pointedly disputed Whately's ideas. For rhetorical purposes, Broadus adopted the better view, in the opinion of this writer. In each situation the determinant of presumption must be the audience. To claim presumption based upon tradition, for example, while addressing a group which holds no respect for tradition is folly. It is axiomatic in speech theory that a speaker 
must analyze the audience and prepare and present a speech accordingly.

As for burden of proof, Broadus also held the better view, rhetorically speaking. Following whately, one might fail to assume the burden based upon an an inaccurate estimate of presumption. Consequently, the speaker would fail to prove a proposition to the satisfaction of an audience. This difficulty was illustrated previously by a hypothetical sermon on the subject of infant baptism. Because tradition favors the practice of infant baptism, one whose propositions favors the custom might assume that he enjoyed presumption and fail to prove his propositions in his speech. If he were addressing a group of Baptists, he would fail to satisfy his audience because he had mistakenly placed the burden of proof, as far as that audience was concerned.

Following Broadus's notion that he who alleges must prove, one will always argue to support his viewpoint. An audience's predisposition in favor of one's viewpoint may remove the necessity of extensive proof. But following Broadus's dictum, a proposition would not fail for lack of any proof. In the hypothetical example cited above, the speaker would assume that all of his statements should be proven. His arguments might not prove these propositions conclusively, but they would be more likely to convince a skeptical audience than mere assertions would be. 


\section{Suggestions for Further Study}

The limitations identified above suggest several types of studies which could be done to expand the present work. Following are a few suggestions.

First, Rosenfield's model for critical discourse includes four variables: the message, the source of the message, the environment, and the critic. The message, according to Rosenfield must be included in all analyses, but other combinations of variables are also possible. For example, a study of the same discourses could be undertaken examining a combination of message and environment. Such a study would cover the information necessary to examine outcomes of the discourses, providing an additional basis for evaluating the usefulness of the theory.

Another study could use the same critical model, but would employ different elements of argument in the paradigm. The same discourses could be compared to any number of elements of argument, drawn from whately's theories or from the theories of others.

A third type of further study could apply the paradigm developed for this analysis to other sermons and addresses delivered by Broadus. Those chosen for this study were chosen for their controversial subject matter, among other things. It would be informative to analyze 
some of the Professor's typical Sunday sermons to discover how and to what extent he applied whately's ideas in them.

A fourth type of study would be more empirical in nature. The contemporary usefulness of the theory could be tested by developing a series of sermons and addresses applying whately's notions, and evaluating the persuasive effects upon a contemporary audience.

It is this writer's hope that his work will help public speakers in general and preachers in particular to understand and apply elements of argument. Concerning the importance of argument, especially in preaching, the final word belongs to Broadus:

Every preacher, then, ought to develop and discipline his powers in respect to argument. If averse to reasoning, he should constrain himself to practise it; if by nature strongly inclined that way, he must remember the serious danger of deceiving himself and others by false arguments. One who has not carefully studied some good treatise on Logic should take the earliest opportunity to do so. It will render his mind sharper to detect fallacy, in others or in himself, and will help to establish him in the habit of reasoning soundly. The fact that, as so often sneeringly remarked, "preachers are never replied to," should make it a point of honor with preachers not to mislead their hearers by bad logic, and should render them exceedingly solicitous to avoid those self-deceptions, which they have no keen opponent to reveal. -. The delicate perception of truth, and the enthusiastic love for it, will inevitably be impaired by a contrary course. 1

IJohn A. Broadus, Treatise on the preparation and Delivery of Sermons, ed. E. C. Dargan (New York: Hodder and stoughton, 1898), p. 170 . 
Ashby, Jerry Paxton. "John Albert Broadus: The Theory and the Practice of His Preaching." Th.D. dissertation, New Orleans Baptist Theological Seminary, 1968 .

Barrett, Robert N. "Dr. John A. Broadus." The Seminary Magazine 8 (April, 1895): 339-42.

Barron, James Roland. "The Contributions of John A. Broadus to Southern Baptists." Th.D. dissertation, Southern Baptist Seminary, 1972.

Broadus, John A. A Treatise on the Preparation and Delivery of sermons, fourteenth ed. New York: A. C. Armstrong, 1889.

- Sermons and Addresses. Fifth ed. Baltimore: R. H. Woodward and Company, 1890.

- "Should Women Speak in Mixed Public

Assemblies?" Louisville: Baptist Book Concern, 1890 .

- A Treatise on the Preparation and Delivery of Sermons. Edited by E. C. Dargan. New York: Hodder and Stoughton, 1898.

- A Treatise on the Preparation and Delivery of Sermons. Edited by Jesse Weatherspoon. New York: Harper \& Row, Publishers, 1944.

- A Treatise on the Preparation and Delivery of Sermons. Revised by Vernon L. Stanfield. San Francisco: Harper \& Row, Publishers, 1979.

"The Duty of Baptists to Teach Their Distinctive Views." Philadelphia: American Baptist Publication society, n.d.

"Immersion Essential to Christian Baptism." Philadelphia: The Bible and Publication Society, n.d. 
Dearin, Ray D. "The Philosophical Basis of Chaim Perelman's Theory of Rhetoric." In Philosophers on

Rhetoric. Edited by Donald G. Douglas. Skokie: National Textbook Company, 1973.

An Eminent Professor of Homiletics. "Criticisms on Some of the Ablest Representative Preachers of the Day: Rev. John A. Broadus, D.D." Homiletic Review 16 (August, 1888): 99-106.

"Criticisms on Some of the Ablest Representative Preachers of the Day: Rev. John A. Broadus, D.D." Homiletic Review 16 (September, 1888): 20712.

Encyclopedia Britannica, 11 th ed. S.v. "Rhetoric," by R. C. Jebb.

- S.v. "Whately, Richard."

- 15th ed. S.v. "Whately, Richard."

Fant, Clyde E., Jr., and Pinson, William M., Jr. Twenty Centuries of Great Preaching. 12 vols. Waco: Word Books, Publishers, 1971.

Fitzpatrick, William John. Memoirs of Richard Whately. 2 vols. London: Richard Bentley, Publisher in ordinary to Her Majesty, 1864.

Folk, Edgar E. "As a Preacher." The Seminary Magazine 8 (April, 1895): 373-75.

Golden, James L.; Berquist, Goodwing F.; and Coleman, William E. The Rhetoric of Western Thought. Second ed. Dubuque: Kendall/Hunt Publishing Company, 1978 .

Golden, James L. and Corbett, P. J. The Rhetoric of Blair, Campbell, and Whately. New York: Holt, Rinehart and Winston, Inc., 1968.

Huber, Paul. "A Study of the Rhetorical Theories of John A. Broadus." Ph.D. dissertation, University of Michigan, 1956.

Jones, Edgar Dewitt. The Royalty of the Pulpit. New York: Harper \& Brothers, 1951.

Jones, J. William. "As Evangelist in Lee's Army." The Seminary Magazine 8 (April, 1895): 353-358. 
Latourette, Kenneth S. Christianity in a Revolutionary Age. Vol. 2: The Nineteenth Century in Europe. New York: Harper \& Brothers, Publishers, 1959.

McGlothlin, W. J. "John Albert Broadus." The Review and Expositor 27 (April, 1930): 141-68.

Moses, Rabbi Adolph. "As a Conversationalist." The Seminary Magazine 8 (April, 1895): 382-84.

Parrish, Wayland Maxield. "Whately and His Rhetoric." Quarterly Journal of Speech 15 (February, 1929): 58-79.

Pence, Orville L. "The Concept and Function of Logical Proof in the Rhetorical System of Richard whately." Ph.D. dissertation, University of Iowa, 1946.

"The Concept and Function of Logical Proof in the Rhetorical System of Richard whately." Speech Monographs, March, 1953, pp. 23-38.

Pomeroy, Ralph S. "Whately's 'Historic Doubts:' Argument and Origin." Quarterly Journal of Speech 49 (February, 1963): 62-74.

Robertson, Archibald T. "As a Teacher." The Seminary Magazine 8 (April, 1895): 359-64.

- Life and Letters of John A. Broadus.

Philadelphia: American Baptist Publication Society, 1901 .

Rosenfield, Lawrence. "The Anatomy of Critical

Discourse." In Methods of Rhetorical Criticism: A Twentieth Century Perspective, pp. 148-74. Edited by Bernard L. Brock and Robert L. Scott. Detroit: Wayne State University Press, 1980.

Starr, Edward C., ed. A Baptist Bibliography. 25 vols. Chester: American Baptist Historical Society, 1953.

Stanfield, Vernon L. Favorite Sermons of John A. Broadus. New York: Harper \& Brothers Publishers, 1959.

Thayer, Joseph Henry. A Greek-English Lexicon of the New Testament. Corrected ed., New York: Harper \& Brothers, Franklin Square, 1889. 
Webber, F. R. A History of Preaching in Britain and America. 3 vols. Milwaukee: Northwestern Publishing House, 1952-57.

Whately, E. Jane. Life and Correspondence of Richard Whately, D.D. 2 vols, London: Longmans, Green, and $\mathrm{Co.1} 1866$.

Whately, Richard. Elements of Logic. Reprinted from ninth ed., London: Longman, Green, Longman, Roberts, and Green, 1864 .

- Elements of Rhetoric. Edited by Douglas Ehninger. Carbondale: Southern Illinois University Press, 1963.

Whitsitt, w. H. "Remarks Made at the Funeral." The Seminary Magazine 8 (April, 1895): 411-413. 